\title{
AFEHANLSTAN FDRUA
}

\section{EDNTENTS}

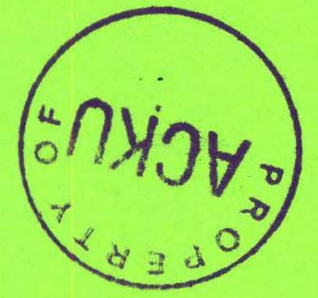

VEL. XIV

September, 1986

กอ. 5

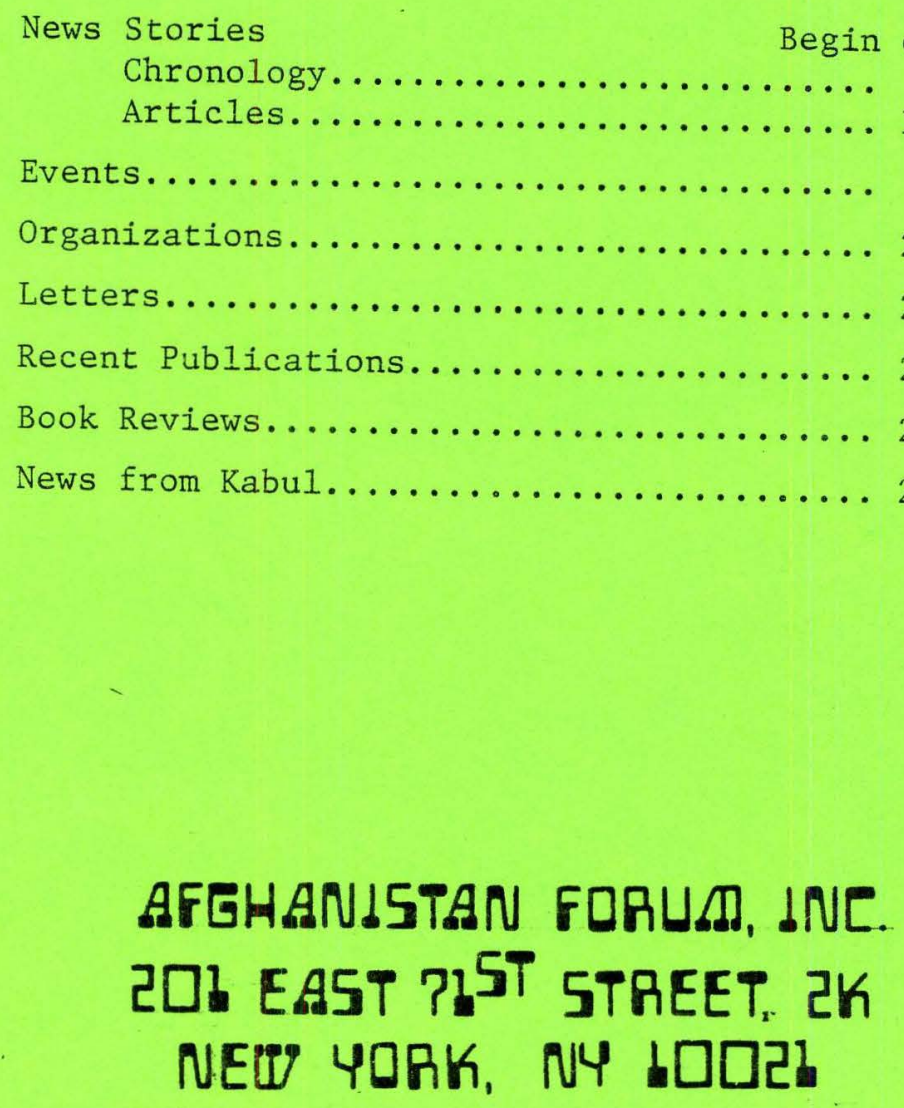




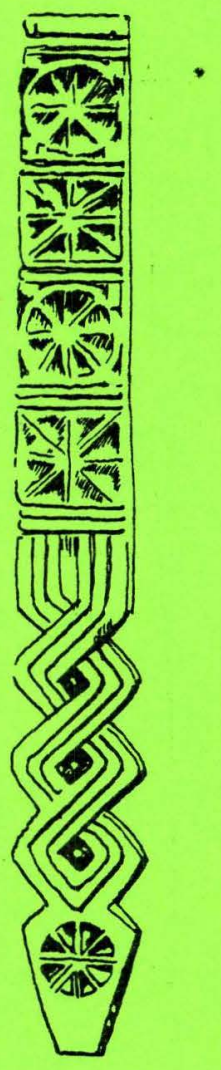

ABBREVIATIONS USED

AICMB - Afghan Information Center Monthly Bulletin
AWSJ - Asian Wall Street Journal
BIA - Bakhtar Information Agency
CC - Central Committee
CSM - Christian Science Monitor
DRA - Democratic Republic of Afghanistan
DYOA - Democratic Youth Organization of Afghanistan
FEER - Far Eastern Economic Review
FRG - Federal Republic of Germany
IHT - International Herald Tribune
KNT - Kabul New Times
NFF - National Fatherland Front
NWFP - Northwest Frontier Province
NYT - New York Times
NYCT - New York City Tribune
PDPA - People's Democratic Party of Afghanistan
PSFO - Peace, Solidarity \& Friendship Organization
PT - Pakistan Times
RC - Revolutionary Council
RTV - Refugee Tent Village
SCMP - South China Morning Post
UNGA - United Nations General Assembly
UNHCR - United Nations High Commission for Refugees
WDOA - Women's Democratic Organization of Afghanistan
WSJ - Wall Street Journal

Line drawing from the 1982 Afghanistan Calendar of the Chicago Afghanistan Relief Committee.

Please send items for the AFGHANISTAN FORUM to

The Afghanistan Forum, Inc.

201 East 71st Street, 2K

New York, NY 10021, USA.

The opinions expressed in the FORUM are those of the parties \& publications involved and are not necessarily those of the Afghanistan FORUM. Listing of organizations does not necessarily imply endorsement.

Subscription rates: $\$ 20$ per year (US \& Canada) (Add $\$ 5$ for FORUM PAPERS)

6 issues/year

$\$ 24$ per year (foreign); airmail Europe - \$35; Asia $\$ 40$.

$\$ 35$ per year (institutions)

$\$ 45 ;$

$\$ 50$.

(includes FORUM PAPERS)

ISSN $0889-2148$ 
OCCASIONAL PAPER 非26, "A Guide to Documents from the Nest of Spies," by Giorgio Vercellin is finally off the press. Copies will be sent to those who included the price in their last year's subscription. Readers who did not, but would like a copy, may order one for $\$ 5$. (The non-subscriber price is \$8.) The paper is a descriptive listing of the documents pertaining to Afghanistan which were taken from the American Embassy in Tehran in 1979 by Iranian students.

The Forum will be taking a booth at the annual meeting of the Assn. for Middle East Studies in Boston, Nov. 20 23. We hope to have our directory of Organizations Interested in Afghanistan ready for the occasion. Please tell us about any organizations you know of as we would like to make the directory as complete as possible.

News reports from Afghanistan were even sparser than usual so the chronology is a rather unharmonious duet between Bakhtar \& the Pakistan Times with descants from the AICMB \& various other Times - LA, NY, London \& Kabul New.

Thanks to everyone who sent us items. Keep them coming. The deadline for the next issue is October 15.

\section{My Green Empire}

\author{
By David Holahan
}

EAST HADDAM, Conn: - It is clear to me now why the Soviet Union clings to its burdensome, ill-gotten empire in Eastern Europe - as well as its latest territory, Afghanistan. What is also coming into sharp focus is the Reagan Administration's preoccupation with "freedom" in Nicaragua, Grenada and further-flung places, like Angola.

You see, the other day while I was mowing the lawn, which is really an underdeveloped weedy parcel within a four-acre hay field, I noticed that the "civilized" plot was progressively expanding. Unconsciously, with each two-week cutting, I had gradually pushed beyond the ever-expanding boundaries. Deliberate plans were also in the works to replace perfectly nice wild plants with cultivated ones, including a hedgerow. It suddenly dawned on me that I had become what the Chinese are fond of calling a hegemonist.

Not only that, but I came to the realization that my Eastern liberal education was all for naught. The student radical, circa 1970, had unquestionably developed into an imperial homeowner, an aggressive horticulturalist, a subscriber to Better Homes and Gardens.

Before my epiphany amidst the amber waves of weeds, I had been developing a program to invest iarge amounts of lime, fertilizer and herbicides to transform my radical patch into a radical vision of what a lawn should be. This two-year plan, known around the neighborhood as "The Great Leap Greensward," would eradicate diversity among the blades and foster a uniform emeraid surface. Dissident dandelions and chicory were to be put on notice: the dictatorship of the landscaper must never be breached. The utopian lawn would tolerate no parasites. Running dogs - capitalist or otherwise - would be discouraged as well.

Until my moment of revelation, I had not seen my burgeoning green empire as sinister. My goal was merely to let bluegrass be bluegrass, and to fight for its freedom from the nefarious clutches of pokeweed and nettles. It was common knowledge that being soft on crabgrass was an ill-advised, pusillanimous policy. If you gave stinkweed an inch, it would take a dozen more. A homeowner either stood tall against creeping buttercup - or gave in. Likewise, as any duffer would tell you, appeasement of burdock leads inevitably to the end of fairways.

But perhaps I was wrong, or had taken matters too far. Don't weeds and rabbits, bugs, moles and fellow travelers, too - have rights? What is so sacred about bluegrass, especially when propped up by costly chemical subsidies and battalions of motorized vehicles?

Indeed, what would be the logical extension of my pervasive green ideology? I could keep annexing new territory, swath by widening swath. And one day I would find myself marching around all four acres of what was once a hay field but had become a uniform, manicured lawn. At this advanced stage of landscaping, the mowing would approach infinity, would in practical terms be perpetual. Upon finishing the job in some remote niche of my lawn-dom, it would be time to start from the beginning again. Such is the awful truth about domination of the grasses, steppe by agonizing steppe.

David Holahan, a writer, lives in Connecticut. 


\section{EUENTS}

\section{PEACE CORPS PROGRAM}

Returned Afghan Peace Corps Volunteers are planning an Afghan program at the 25 th anniversary celebrations of the Corps in Washington, D.C. on 9/20. A panel on recent events and a dinner are on the schedule. Contact Michael W. Albin, 5603 Ventnor Lane, Springfield, VA 22151 (703-978-3022), for details.

\section{PHOTO SHOW}

Luke Powe11: The Afghan Folio, an exhibition of 32 color photographs of Afghanistan, will be shown at George O'Bannon's Oriental Rug Gallery, 2100 Spring Street, Philadelphia, PA 19103 (215-557-6555), from 9/29 through 10/30. An opening reception will be held on $9 / 29$ from 5 - 9 p.m; Mr. Powell will lecture at $7: 30$.

\section{BRITISH CONFERENCE}

Afghanistan: The Way Forward was the topic of a British Foreign \& Commonwealth Office seminar held $7 / 10$ in London. Speakers included the Rt. Hon. Lord Home, Mr. Egger, Under Sec'y for Foreign \& Commonwealth Affairs, Olivier Roy, Anthony Hyman, Adam Roberts \& Eileen Denza.

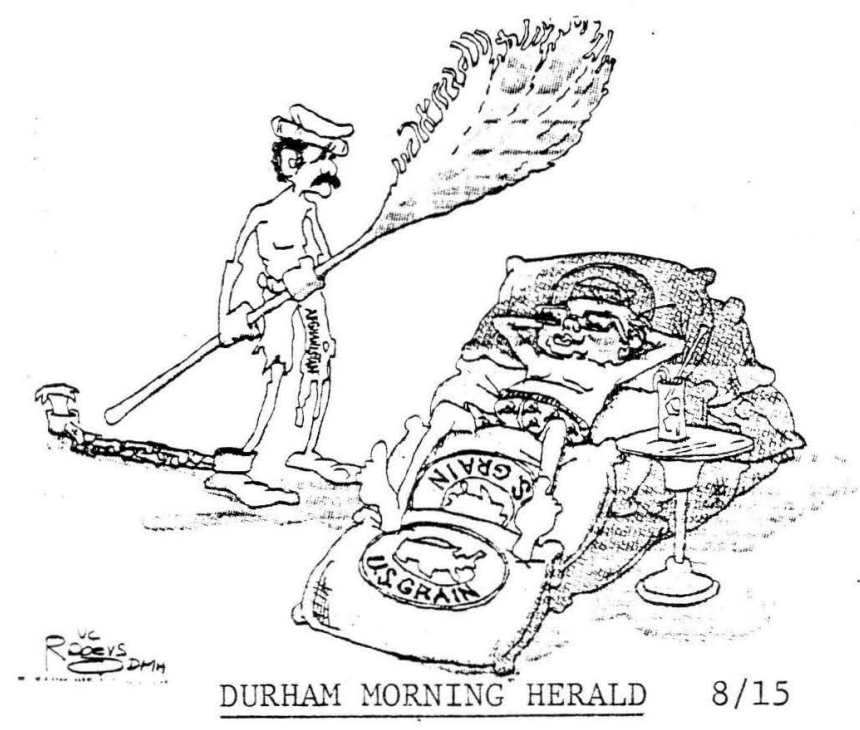

AFGHAN NEWS (8/15) reports on a letter it received from Cdr. Masood describing the offensives in Baghlan, Qunduz \& Takhar provinces. Mujahideen in Andarab, Nahrin, Eshkamish, Khost, Ferkhar, the center of Takhar \& Qunduz have started to form Shoora (counsels) to consult among themselves. Training of local groups \& commanders has made good progress. In each area the commanders are chosen by the local mujahideen.

Starting $6 / 9$ the Soviet air force bombed the Khailab Valley from dawn to dusk for 10 days - from 50 -100 missions every day.

On $6 / 12$, the 7 th, 18th $\& 20$ th DRA divisions $\&$ the 20th Soviet division reached Kunduz. Police \& other operative units from Baghlan participated in the operations. The enemy reached Eshkamish on $6 / 15 \&$ on $6 / 17$ helicopters landed over 3,000 Soviet commandos in the Khailab Valley (where the Mujahideen strongholds are located.)

Mujahideen destroyed 4 helicopters \& stopped the advance toward Eshkamish. The general operational $\mathrm{cdr}$ of the Soviet forces was killed along with over 200 enemy commandos. The Soviets captured a base at Ittehad.

Our [Jamiat] casualties numbered 5; 100 civilians from Khailab, Eshkamish \& Khost were martyred; others were wounded, "The enemy defeat despite the deployment of a large force was without precedent in this area in 7 years of war... Now the enemy forces have taken positions in Kunduz, Takhar \& Faizabad \& are protecting the road with hundreds of tanks. They are busy resupplying their garrisons. "In Khanabad, Mujahideen were hesitant to engage the enemy in the flat areas" being afraid that the Soviets would burn the harvest. The enemy did just that $\&$ established many posts around the city. "The enemy has deliberately destroyed the irrigation systems to prevent people from sowing rice. The situation in Farkhar, Wursaj \& Kalafgan is similar.... In the 3 provinces about 500 civilians were martyred \& the same number injured. ..." 


\section{EHRONDLDEY}

6/15 - BIA - The 5th anniversary of the NFF was celebrated in Kabul (see $6 / 18 \&$ p. 31).

- Transportation Minister Sherjan Mazdooryar said that land transport facilities in the DRA will increase 1.6 times during the 1st post-revolution 5-year plan (1986-91).

- The main buyers of DRA medicinal herbs are Czechoslovakia, Italy, France, Sweden, USA, India, Pakistan $\&$ Japan. Licorice is the main export item.

6/15 - PT - The European Parliament called for the Soviets to leave Afghanistan (see p. 10).

- AICMB 非4 - A bomb exploded in the Ministry of Agriculture in Kabul killing $11 \&$ injuring 26 including a soviet adviser.

6/16 - Newsday - The DRA acknowledged that the civil war was "worsening \& expanding" \& announced a drive to expand the army.

- BIA - The RC military draft decree was announced. (See p.32 for text.) - Resolution 非54 of the Council of Ministers exempts farmers from paying interest \& fines on last year's loans from the Agricultural Development Bank. The resolution affects about 160,000 farmers.

- Each haj pilgrim was offered Afs. 18,000 for airfare to Jeddah. Over 5,000 are expected to make the pilgrimage. (See 8/18.)

- Comrade Najib visited Shindand air base \& some border regiments in Herat \& in Zaranj city in Nimroz. He was accompanied by Defense Minister Gen. Nazar Moh'd \& State Security Minister Gen. Ghulam Faruq Yaqubi (see 7/28).

$6 / 17$ - BIA - Retail trade volume in the DRA will reach Afs. $21 b$ by 1991 .

6/18 - AICMB 非64 - In Kabu1, Babrak supporters distributed leaflets against Najib \& the Soviet leaders. Khad agents collected all the fliers the next morning.
6/18 - BIA - Over 270,000 Afghans belong to trade unions; elections have begun in Parwan; national leaders \& private investors will invest over Afs. $500 \mathrm{~m}$ in construction projects in Kabul.

6/19 - AICMB 非4 - Air traffic was suspended for several hours at Kabul airport because of rocket attacks.

- BIA - NFF statistics: 800,000 members; 29 provincial councils, 30 city councils, 61 ward councils; 2 grand district councils, 122 district councils, 49 sub-district councils, 1132 village councils.

- Elections began in Khost, Paktia.

$6 / 21$ - PT - Mujahideen stormed the governor's house \& the local party headquarters in Charikar, Parwan on $6 / 10$.

$6 / 22$ - $\underline{P T}$ - 39 wounded Afghans, including 2 women \& 5 children, are in the US for medical treatment courtesy of the Committee for a Free Afghanistan. (Henry Kriegal has replaced Karen McKay as CFA Director.)

6/24 - BIA - Since 1980 over 200 transportation workers have been martyred by counterrevolutionaries.

6/25 - PT - Burhanuddin Rabbani, in France after meeting with Pres. Reagan in the US, met with French Prime Minister Jacques Chirac \& Foreign Minister Jean-Bernard Raimond. M. Raimond "reaffirmed France's condemnation of the Soviet intervention in Afghanistan \& France's promise of humanitarian aid to the poople \& Afghan refugees.

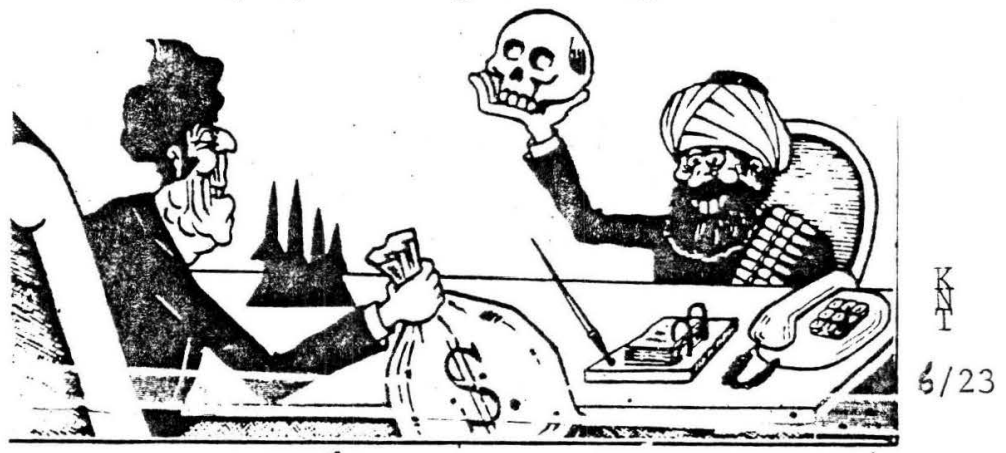

Rearan received ban theaders in White House and promised more aid to them-Newe

- BIA - By the end of the 5-year plan (1991) over $2 \frac{1}{2} \mathrm{~m}$ Afghans will have 1iteracy certificates. 
6/26 - AICMB $\# 64$ - In Ningarhar, gov't posts at Umarkhe1 \& Dandu in the Surkhrud District were destroyed. The commander, known as Mumtaz, who had been a mujahideen cdr. four years ago before he defected to the DRA, was captured.

- PT - The Kabul regime has suddenly reinforced its defenses along the 100-mile Pak-Af border between Chaman \& Noshki.

BIA - The new DRA labor law ensures equal job opportunities for all, regulates the relationship between workers \& management in the state \& private sectors, "provides for the moral values leading to motivate the workers," gives special concessions to women from pregnancy until their children are 8, classifies occupations, calls for better working conditions, specifies remuneration for "damages" $\&$ calls for the "supply of cultural services," training \& complete eradication of illiteracy. "The concessions given to the workers, particularly to the women... are unprecedented in the history of Afghanistan."
$6 / 28$ - BIA - "Strengthening the ranks of the armed forces by drafting volunteer youths throughout the country is the leading story of the Afghan press." The main papers are the daily Hewad, the official organ of the RC \& the Council of Ministers; the daily Haqiqat-e-Enqlab-eSaur \& the week1y Dehqan (peasant), the official organs of the PDPA CC; the daily Anis, the offical organ of the $\mathrm{NFF}$; \& the weekly Pamir, the official organ of the Kabu1 City PDPA Party Committee.

$6 / 29$ - PT - Tehran Radio reports that Information \& Culture Minister Sarboland \& Foreign Minister Shah Moh'd Dost are not cooperating with other DRA communist leaders since Babrak's removal. [BIA releases identify Sarboland only as Dep. Chmn. of the Council of Ministers \& Pres. of the Afghan-Indian Friendship Assoc. Ed.]

- The Chinese Red Cross donated \$100,000 worth of relief goods to Pakistan for Af:ghan refugees.

- BIA - In 1985 the DRA subsidy for "meeting social needs of the workers" was Afs. 2.8b; salary increases for state employees cost Afs. 3b.

\section{$6 / 27$ - NYT - Elaine Sciolino writes} on the Geneva talks:

- "We are not on the verge of a breakthrough," a Pakistani official said.

The two sides are farthest apart on the schedule for withdrawing the 120,000 Soviet troops in Afghanistan. At a meeting last month in Geneva, Afghanistan proposed a four-year schedule, and Pakistan called for six months, according to the sources. The Afghans agreed to negotiate on the period, hinting that they might shorten it to three or three and a half years. Pakistan still considers that too long.

"The Pakistanis are not going to engage in anything that is transparently a sellout," a State Department official said. The United States position is that Soviet forces could be out in three to four months.

Afghanistan and Pakistan also have yet to agree on how to monitor a cutoff of aid from Pakistan to Afghan guerrillas before a troop withdrawal begins. The Soviet Union wants all "interference" and "intervention" to stop before a withdrawal, in elfect cutting off the guerrillas' supply lines. The Russians aiso oppose a United Nations monitoring force on the border and are asking for verification by Pakistan and Afghanistan.
Pakistan is willing to allow outside monitoring on the border, but under United Nations supervision, and is demanding similar monitoring of a Soviet troop withdrawal.

Pakistani and American officials have expressed fear that if the Soviet forces have too much time to withdrav after the supply lines are cut, the could destroy the Afghan guerrillas.

There is also no agreement on aa issue that is to be dealt with outside the present negotiations: the nature of the Afghan Government after a Soviet withdrawal.

"It is always hanging over the negotiations, like a cloud," a United $\mathrm{Na}-1$ tions official said.

In response to Soviet insistence that Afghanistan must have a friendly government, a Pakistani official said his Government would accept a "pragmatic" solution. This meant Pakistan would be willing to recognize that the Afghan Government had been proSoviet for decades and would probabiy continue to be pro-Soviet.

The officials have not even addressed the issue of finding a government accepable both to the Soviet Union and to the Afghan guerrillas...

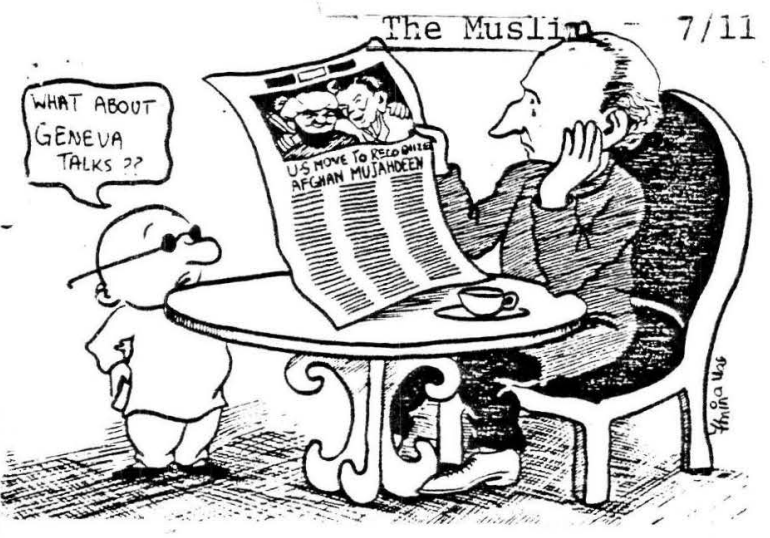

6/29 - NYT - Gorbachev on Afghani-

stan: Moscow, June $28-$ Following are excerpts from Mikhail S. Gorbachev's speech today in Vladivostok, as distributed in translation by the Soviet press agency Tass.

Having thoroughly assessed the situation that has developed and hav. ing held consultations with the Government of the Democratic Republic of Afghanistan, the Soviet leadership has adopted a decision that I am officially announcing today: 


\begin{abstract}
Six regiments will be returned home from Afghanistan before the end of 1986 - one armored regiment. two motorized rifle regiments and three antiaircraft artillery regiments - with their integral equipment and armaments. These units will be returned to their areas of permanent deployment in the Soviet Union, in such a way that anyone interested can easily verify it.

In taking so serious a step, the Soviet Union is striving to speed up a political settlement, to give it another impetus. The Soviet Union also proceeds from the view that those who have been organizing and implementing armed intervention against the Democratic Republic of Afghanistan will correctly understand and duly appreciate this unilateral step of ours. It must be answered by the curtailment of outside interference.

Certain progress has been achieved of late in the Afghan-Pakistani talks held through the mediation of a representative of the United Nations Secretary General. As soon as a political settlement is finally worked out, the return of all Soviet troops can be speeded up. Schedules for their stageby-stage return have been agreed on with the Afghan leadership.
\end{abstract}

7/1 - PT - Mujahideen reportedly destroyed a Soviet motor boat on 6/14 on the Amu River. The Soviets bombed the Darwaz area in retaliation on $6 / 15$ causing many casualties.

- BIA - Electric Energy Minister Raz Moh'd Pakteen told Bakhtar that power output will increase $1 \frac{1}{2}$ times by 1991 . His ministry will build 10 smallscale hydro-power plants in various provinces at a cost of Afs. $200 \mathrm{~m}$ which will come from state sources as well as foreign aid from India \& Bulgaria. - Iranian mullahs reportedly intend to organize "Afghan bandits" into regular units \& send them into the DRA to commit "inhuman crimes."

- KNT - The Afghan charge d'affaires in Karachi, Baz Moh'd Rahiab, disappeared on $6 / 25$. DRA investigations show he was abducted by the CIA, aided by the Pakistani CID (see 7/4

\& p. 14).

- All the houses in Kabul will be

"numbered" \& the family members counted by the 3 rd quarter of this year.

$7 / 2$ - NYT - Mujahideen reportedly shot down a military transport plane carrying 100 Soviet soldiers between Kabu1 \& Kandahar.
$7 / 2$ - BIA - According to Sultan Ali Keshtmand, elections for representatives to the local organs of state power have been completed in 16 provinces \& in Kabul city. Elections in the other provinces will be completed by August. Over 1,000 people have been elected to administrative positions $\&$ over 8,000 as regular members of local committees. When the elections are completed these numbers will be tripled. - Pakistan Affairs (7/16) -

ISLAMABAD-Zain Noorani. Minister of State for Foreign Affairs, on July 2 denied the allegation that Pakistan was providing military training to Afghan Mujahideen on its territory.

Replying to an adjournment motion which drew the attention of the Government to a Radio Moscow broadcast. Mr. Noorani said: "The factual position is that no military training of any sort is being provided to the Afghan resistance on Pakistan territory.

$\mathrm{Mr}$. Noorani said the Soviet technique of planting such false and baseless reports in the Indian media, particularly in pro-Soviet Indian newspapers, and then quoting its own planted stories in the Soviet media was too well known. "It is supposed to be one of the clever techniques of modern propaganda designed to convince the audience that the story comes from an objective third source instead of an interested party. But no one should be fooled by these reports." he said.

7/4 - PT - The acting Afghan Consul Gen'1 in Karachi, Baz Moh'd Rehyab, left voluntarily with his family for Frankfurt, according to Pakistani authorities (see p.14).

7/5 - PT - The president of the Azad Gov't of Jammu \& Kashmir inaugurated a dispensary $\&$ 10-bed hospital for Afghan refugees in Quetta.

- BIA - The private investment committee approved the establishment of over 30 private sector projects with a capital investment of Afs. $240 \mathrm{~m}$. Projects will include shoe \& shoe polish making, carpet weaving, poultry farms, confectionery, "carpentry \& sculptures," \& metal works.

7/6 - BIA - Over 1,000 Afghan Shi'ites met in Kabul to express support for the establishment of a central council for the Hazara nationality, the activities of the NFF \& the programs of the PDPA.

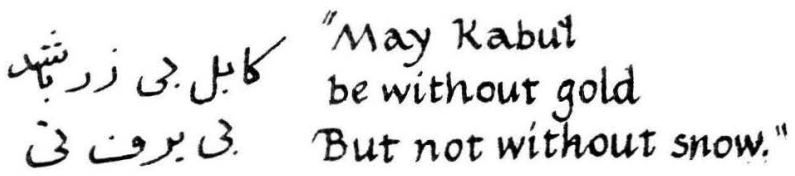


7/8 - BIA - By 1991 private sector production. will increase $14.8 \%$ in agriculture, $21.3 \%$ in industry \& $36.3 \%$ in construction over the last Afghan year.

7/11 - BIA - Comrade Najib told 19th plenum members that the local organs of state power, which are not yet functioning properly, should strive to make villages function through peaceful means. - The PDPA \& the Working People's Revolutionary Assn of Afghanistan (WPRA), "a left-wing democratic organization" founded in 1972, have joined together (see $7 / 20$ ).

$7 / 12$ - AICMB $\#_{64}$ - Mujahideen fired rockets at the Soviet Embassy compound in Darulaman \& hit 2 apartment blocks. - Kabul schools reopened after students staged an 8-day boycott protesting the new military regulations.

$7 / 13$ - PT - Tehran Radio reported that Herat is now fully under mujahideen control although the Kabul regime has sent reinforcements. The "road link of the area with Kabul has been disconnected for the last 10 days." (See $7 / 14,7 / 15 \& 7 / 22,7 / 28$.)

- BIA - Peasants form $25 \%$ of the DRA population - over $3.6 \mathrm{~m}$. Afs. $15 \mathrm{~b}$ will be earmarked for agriculture in the new 5-year plan: $\mathrm{Ca} 4 \mathrm{~m}$ hectares of land will be cultivated; the gross agricultural product will increase $16 \%$; 70,000 hectares of 1 and will be irrigated; cereal \& grain production will reach $5 \mathrm{~m}$ tons.

7/14 - The Times (London) - Tass reported that DRA forces routed a rebel attack on Herat killing dozens of guerrillas including 13 "bandit leaders." AICMB 非64 reports the following commanders killed in the Herat fighting: Qazi Abd-u-Rahim, Mama Abdul Ali, Sofi Moh'd, Hanif Jan, Imamuddin Askar, $A b-$ dul Qudus \& Mohayudin. Ábdullah Jan, Haruz Karbas, Niaz Ahmad Kishk, Qazi Moh'd \& Safi Habib Choongar were killed when their jeep hit a mine. The DRA commander of Herat, Gen. Juma Khan Asak, lost both legs when a Soviet shell landed near him. He was sent to the USSR for treatrent but is presently back home.
$7 / 14$ - BIA - The total economic loss from the "destructive action of the counter-revolutionaries" is Afs. 36b.

$7 / 15$ - $\underline{\text { PT }}$ - BBC reported that fighting had been heavy in Herat for the past month \& that mujahideen control all but one part of one bazaar in the center of the city. BBC also said that the frequent bomb blasts in the NWFP appear to be part of a new DRA gov't policy to make Afghan refugees unpopular in Pakistan \& to try to make them return home.

7/16 - BIA - "The special revolutionary court...proclaimed Ahmad Shah Masood an enemy of the people's happiness \& a tool of the enemies of Afghanistan." He was sentenced to death in absentia. The AICMB (July) reported that Massud had been working in the northern areas of Afghanistan for some months, training mujahideen groups \& coordinating their attacks. (See p 2.)

$7 / 17$ - BIA - Elections began in Badghis. - "Traveler," a new Afghan film which won a prize at the Tashkent Int'1 Film Festival, opened in Kabul. The film shows farmers being exploited by "feudals." (See p. 33 for more about films.)

$7 / 18$ - PT - The Kabul regime has urged security forces to raise 3 army units of 3,000 soldiers each within a week. A recent conscription drive reportedly included some foreigners "including UN employees whose release was only secured after a great deal of effort."

$7 / 19$ - NYT - Pakistan's Prime Minister Moh'd Khan Junejo said at a press conference in Washington that the USSR had formally offered to withdraw its troops from Afghanistan over a 4-year period. Pakistan feels 4-months is sufficient.

- BIA - The Bakhtar political observer noted that he could seev "no signs of goodwill about the political solution of the situation around Afghanistan in the talks between Reagan \& Junejo: "they purposefully ignored the flexible policy of the state of the DRA." 
7/20 - BIA - The PDPA CC has 147 full \& alternate members: 12 are workers, 7 farmers, 5 women; 81 are Pashtoons, 50 Tajiks, 5 Uzbeks, 2 Hazaras, 2 Baluchis, 2 Turkman, 1 Pashai, 1 Nuristani \& 1 Arab; 46 are serving in the provinces, 8 in foriegn countries. 20 additional people were elected to the "audit commission" of the CC.

- A special commission has been set up to look into the problem of "national reconciliation."

- Two "left-wing" organizations have joined the PDPA (see 7/11), 3 others are about to join \& another has "voiced its cooperation."

- The fare on a killi bus is 1 Af.

- Comrade Najib explains it all: "A Muslim is grateful to anyone who provides him a cup of drinking water in hot weather. How can the people of Afghanistan not be grateful to the Soviet Union who has rendered assistance for the ensuring of independence, national sovereignty \& protection of Afghanistan. It renders assistance to the DRA in socio-economic fields \& its best sons are killed for the sake of Afghanistan. Only an elder brother can render such great assistance."

7/22 - AICMB $\#^{6} 64$ - Sebghatullah Mojaddedi became the speaker for the Islamic Alliance of Mujahideen.

$7 / 23$ - PT - In a press conference Burhanuddin Rabbani said that the Islamic Unity would shortly form a National Assembly (Shoora-i-Milli) to enlarge the scope of the resistance efforts. The group will represent 216 districts of Afghanistan \& will be responsible for evolving major policy decisions. Rabbani said he opposed the idea of a government in exile (see p. 17) but supported any move to form a parallel gov't inside Afghanistan.

- LA Times - At least 30 explosions, several machine gun battles \& rocket attacks shook Kabul last week according to western diplomats. Most of the action took place in the Darulman district.

- PT - A report from Herat says that in recent fighting there commander Abdullah Jan, "the one who killed the notorious collaborator Sher Agha Chungar," was killed. Mujahideen have partial control in the western part of the city.
7/24 - PT - An article in an Ottawa paper, The Citizen, put Soviet casualties in Afghanistan at 15,000 dead \& 60,000 wounded. - Mujahideen are reported to have blown up part of the Sarobi Dam on the Kabul River near the Kabul-Jalalabad highway.

$7 / 25$ - PT - Gen. Gregory Ropor Novich has been appointed the new Soviet army chief in Afghanistan. The general "has full control over the puppet troops which are being ordered through Lt. Gen. Moh'd Khitab Janbaz." He lives in a house in front of Babrak's home.

- In the past 3 months the price of food has risen 500\%. Current prices (per kilo): meat - Afs. 375, tea - Afs. 1050 (up from Afs. 650), edible oil - Afs. 650, rice Afs. 150 (up from 66) \& potatoes - Afs. 32 .

$7 / 27$ - PT - Moscow will not agree to Pakistan's proposal that Soviet troops be withdrawn in 3 or 4 months.

- The Mujahideen Press Agency reports that all Afghan students studying in communist countries, including about 50,000 in the USSR, have been called home, presumably for military service.

$7 / 28$ - PT - Dr Najibullah recently visited Herat to boost morale \& counter western reports that the city was under siege.

7/29 - LA Times - Mikhail Gorbachev announced that 6 regiments of Soviet troops will be pulled out of Afghanistan by the end of this year.

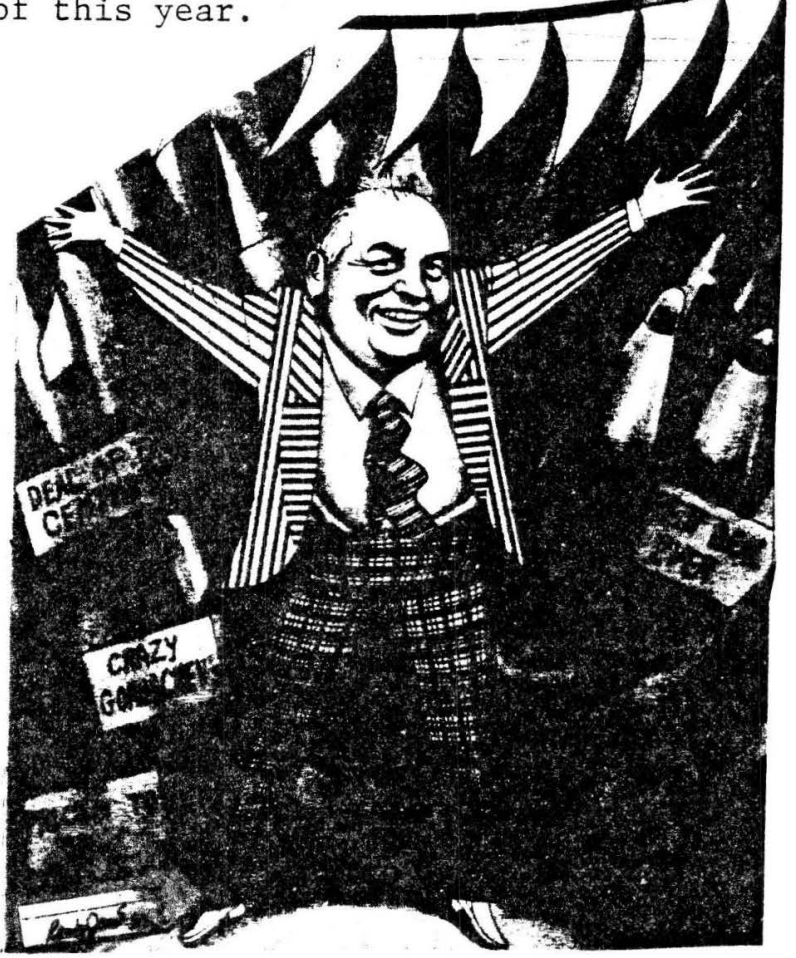


LA Times correspondent William Eaton

writes: Western military experts said the promised withdrawal of 6,000 to 10,000 of the estimated 115,000 Soviet troops in Afghanistan would not have any military importance. Soviet forces have been in Afghanistan since late 1979 , supporting the Marxist government in Kabul against insurgents.

While no figures have been made public on Soviet losses in Afghanistan, accounts in the official press have indicated heavier involvement in combat in recent years. Western sources estimate that at least 10,000 Soviet soldiers have died in combat against Afghan rebels, called moujahedeen or "holy warriors." ...

Speaking in the Far Eastern port of Vladivostok, Gorbachev said the pullback of the six regiments with their weapons and equipment is designed to spur a political settlement of the seven-year-old civil war.

In discussing Afghanistan, Gorbachev said the Soviet government would withdraw two motorized rifle regiments, an armored regiment and three anti-aircraft regiments before the end of 1986 .

Western diplomats said Soviet motornzed rifle regiments usually have about 2,000 soldiers, while armored regiments have about 1,000 and anti-aircraft regiments about 300 . That would mean a total of nearly 6,000 troops in the six units mentioned by the Soviet leader.

Gorbachev said the troops will return to their home bases in the Soviet Union in such a way that "all those who take an interest... . could easily ascertain this." While Gorbachev did not elaborate, he apparently referred to satellite photography conducted by the United States and others. . . .

Military analysts noted that three of the regiments to be withdrawn are anti-aircraft units that are of little use because the guerrillas have no aircraft and there is little prospect that the air force of neighboring Pakistan will become involved in the conflict.

The one armored regiment involved also is of limited value in the rugged Afghan terrain.

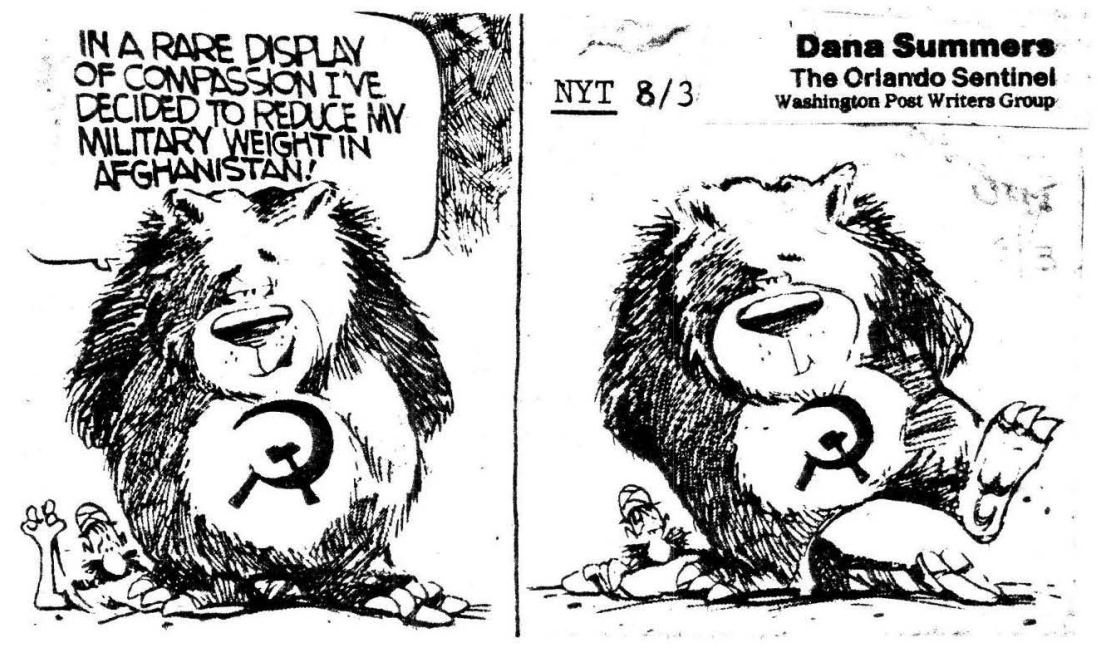

U.S. officials reacted with skepticism to Gorbachev's announcement.

"There is only one acceptable solution to the Soviet occupation of

Afghanistan: the prompt and complete withdrawal of the approximately 120,000 Soviet troops in that country," White House spokesman Larry Speakes said.

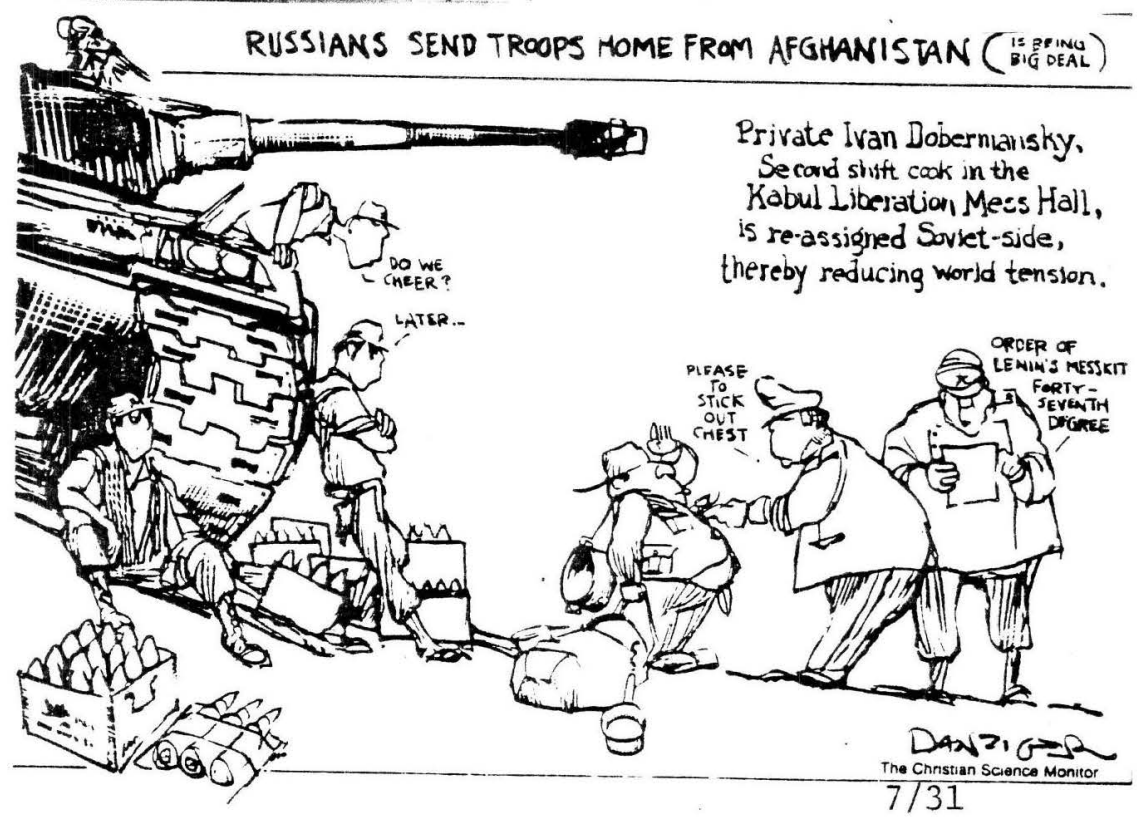

$7 / 29$ - PT - Bakhtar reported that the Afghan economy "has been severely affected by the circulation of counterfeit currency notes." During a press conference thousands of fake notes seized from the trading community were exhibited. Bakhtar says the mujahideen are circulating the notes to sabotage the DRA economy.

$7 / 30$ - LA Times - DRA armor \& aircraft movements southwest of Kabul suggest that a major offensive has begun against Mujahideen in Logar (see 8/1). Diplomats in Delhi report that mujahideen have retaken control of most of Kandahar.

$8 / 1$ - $\underline{P T}$ - Gulbuddin reportedly is inside Afghanistan to commandeer operations in Logar. 
8/1 - NYT - The Pakistani \& Afghan foreign ministers resumed indirect negotiations in Geneva.

8/2 - PT - Diplomatic sources report that Kandahar airport has fallen to the mujahideen. Indiscriminate bombing of civilians is reported in Baghlan.

$8 / 9$ - NYT - The indirect talks in Geneva were suspended indefinitely. The two sides remain far apart but Diego Cordovez denied that there had been a deadlock. He said that the participants had agreed to meet again. "The process is very much alive \& will continue."

$8 / 10$ - PT - VOA reports that the US \& the USSR will meet next month to consider the Afghan crisis since this issue is standing in the way of a possible Reagan-Gorbachev summit this year.

- Saudi Arabia donated 25-30,000

"frozen or chilled carcasses of sacrificial meat" to Afghan refugees in Pakistan for Eid-ul-Azha. (See p. 30 ).

$8 / 12$ - PT - The IHT reported that a number of Arabs, both students \& professional people, joined the mujahideen this summer. Most are from Lebanon, Syria, Egypt \& Jordan \& fight against the Soviets because of their Islamic ideals.

8/13 - LA Times - Mujahideen have stepped up their attacks on Kabul hitting the Soviet \& Polish embassies with rockets. Western diplomats also said Soviet helicopter gunships have been heading south from Kabul indicating intense fighting in Logar.

$8 / 17$ - BIA - August 19 will not only be celebrated as the "restoration day" for the independence of Afghanistan, but also as Army Day.

$8 / 18$ - BIA - The new int'1 terminal at Kabul airport will be completed in November. The building will have 2 stories. A new freight hangar has already been finished.

- 3,000 Afghans made the haj pilgrimage this year. The DRA subsidy for each one was Afs. 35,000.
8/18 - BIA - Moh'd Akbar Kherad is the DRA permanent representative to the UN office in Geneva. The new Soviet ambassador to the DRA is Pavel Mozaev.

$8 / 19$ - BIA - The 1st heroes of the DRA are Lt. Col. Faiz Moh'd, killed heroically in in 1979; Maj. Gen. Ahmaduddin, killed in the Panjsher in 1985; Capt. Sherzamin, a prominent pilot $\&$ 2nd Lt. Juma Khan, a hero of Khost \& Panjsher

- A historical museum was opened in Kabul at the Koti Baghcha Palace, near the entrance of the RC headquarters. Gold,"old coins \& famous painting tableaux" are on display. - Army Day \& the 67th anniversary of Afghan independence were celebrated in Kabul \& in the provinces of Herat, Parwan, Kapisa, Kunduz, Kunar, Nangarhar, Faryab, Farah, Ghazni \& the Panjsher district of Parwan.

8/20 - BIA - Elections began in Kandahar. - An Army Museum was inaugurated. On display are the works of Khushal Khan Khatak \& Ahmad Shah Abdali, "one of the valorous kings of Afghanistan... most ancient weapons 150 years old, helicopters of half a century ago \& various historical tableaus... army uniforms of the old ages... \& various types of mines \& chemical weapons... seized from bandits."

$8 / 21$ - BIA - Over 300 primary schools will be built during the new 5-year plan. - The Politburo fired the Jauzjan Party Provincial Sec'y \& the Kabul Party Provincial Sec'y for their "serious weaknesses" in party work.

- Women: 22,000 are working in production enterprises; 11,000 are engaged in educational \& cultural \& social affairs; a large number have been elected to local organs of state power \& over 5,000 are armed \& defending the revolution.

8/24 - NYT - Benazir on Zia's Afghan policy: Benazir Bhutto, the-most popular anti-Government leader, said in an interview that General Zia's support of the Afghan rebels was ill-advised because millions of Pushtoon refugees from Afghanistan are even less loyal to Pakistan than other Pushtoons. "The Soviets know that the situation is ripening to a stage where the unity of the country is being affected," she said, and Moscow could take revenge by trying to dismember Pakistan.

$8 / 27$ - NYCT - A bomb hidden in a suitcase exploded at Jalalabad airport on $8 / 11$ killing 16 people. No one knows whose bomb it was. Heavy fighting was also reported in Logar, Samangan, where guerrilla casualties were heavy, \& in Parwan. 
AFGHANS MUST UNIFY The Oregonian 5/22

The author of this article, an Afghan living in Portland, has asked that his name not be used because he has family in Afghanistan.

A NEW ROUND of talks regarding the Afghan conflict began this month. A key to these talks is a Soviet proposal submitted in December 1983 offering withdrawal of Soviet troops from Afghanistan if certain conditions were met.

The rumor that Russia will withdraw its troops has been circulating for some time, not only among the Afghans in Pakistan and inside Afghanistan, but also in Washington, D.C.

A negotiated settlement must inevitably reflect the realities on the battlefield. On the one hand, the Soviets are clearly aware that the Marxist regime in Kabul has no support among the people nor will it gain any in the future. On the other hand, they can count on the fact that the people of Afghanistan are tired of a bitter war that has dragged on for more than six years.

Not only has Afghanistan become an experimental field for the tactics and tools of war, it is also a proving ground for ideologi$\mathrm{cal}$ and political theories.

Even before the entry of Soviet troops, special-interest groups backed by foreign capital and foreign governments maneuvered for advantage in Afghanistan. Saudi Arabia formed Wahabi groups, Pakistan aided the Ikhwan groups and the Iranians funded Shiite fundamentalist groups. Leftist European groups were at work with supporters inside the country. Sufi Moslem leaders had connections with Western conservative groups, and the exiled king dreamed of returning from his villa in Rome.

These forces put additional pressure on a society fashioned from a mosaic of different ethnic groups, linguages and religious sects. Dozens of spoke dialects and allegiances to various religious traditions create further divisions betwees groups.

For more than 100 years, attempts to reform Afghanistan into a modern nation have been crippied by a primitive economy and governments mired in factional disputes. The Soviet invasion was seen by many as a rare opportunity for Atgnanistan to overcome political fragmentation and unify against a common enemy. But this optimistic view has been replaced by greater skepticism in the face of deliberate Soviet action and discord among rebel leaders in Pakistan.

In the early stages of the war, the goal of a united front seemed within reach. The people of the central Hazara region were the first ethnic group to liberate their territory from Soviet-led forces. Despite two centuries of oppression by more powerful groups, they led efforts to coordinate operations against the Russians in Tajik, Uzbek and Panjshir areas.
Such efforts taltered when Soviet strategists began directing their counterattacks away from targets in the central provinces. This move rekindled tribal and regional feuds as suspicion grew that areas free from reprisal had bought their safety by collaborating with the enemy, even though guerrilla supplies continued to pass through the central provinces.

The situation is equally divisive among the Mujahideen in Pakistan. The exile political groups in Peshawar remain split into seven parties, their leaders attempting to preserve the appearance of political unity while competing for foreign money and supplies to aid the war effort. After seven years in Peshawar, they appear unable to accept the fact that Afghanistan is a multi-ethnic country whose people must share equally in the struggle and in any eventual settlement.

The problem of unity is not easy and cannot be achieved easily. The first and most important step is to draw up a framework broad enough so that the majority of Afghans would find it acceptable. This document should guarantee equal rights for all Afghans, including freedom of religion and beliefs, election on a basis of population, and equal political and social opportunity for all people regardless of ethnic or religious affiliation. The platform should take into consideration the desires, grievances and demands of all factions of Afghanistan.

But the writing of a platform is the easiest step. More important is the guarantee that will be given to skeptical ethnic and political groups that these promises, unlike others, will be kept.

Most of these are practical questions and can be resolved. The most immediate need is for the Mujahideen leadership to put aside petty differences rooted in the past and to commit themselves to a free and unified Afghanistan. They must realize that political power must be shared.

This would be a constructive step toward unity, and ultimately toward a free and stable Afghanistan. To fail is to again invite Soviet intervention.

\section{EUROPEAN PARLIAMENT RESOLUTION}

$$
\begin{aligned}
& \text { Excerpts from The Muslim 6/15 } \\
& \text { The European Pariamene in } \\
& 2 \text { unasimously passed resclution } \\
& \text { yexterday condemned the Sovist } \\
& \text { oceupation of Afginanisian and } \\
& \text { called for the immedinte and un- } \\
& \text { cosditional withdrawal of its troops } \\
& \text { * that Afghaniscas.'s neutral and } \\
& \text { non-aligried status could be res. } \\
& \text { cored. } \\
& \text { The rusoluties tad beer drawr. } \\
& \text { up by the Political Affairs Com. } \\
& \text { mitree of the European Parlia. }
\end{aligned}
$$

The premble of the resolution :et?ects the conciusiens of the report poinring out that the Soviat Union hes been tushring the war is Afgheristan for ores dx years which is longer than the Worid War II, that the *as in Aignanistan has broughe unimaginable

to the Afghen people.

Aceusing the Soviet Union of mass finurder the rasolution states that the Soviat Union holds the ral powes in Afghariats and onake un of a complateiy dependent goverament to which the rosistince is midespread and total It tarms Afghanistan as an example -of the struggle of peoples fot seif-determination, troedom and peace and regards the Afghan resistance as historically comparable to the resistance offered by the Buropean peopie arainst foreign invades and sovalitarian foress rule.

The Soviet Union, the resolution ys, is benring on the fact that the West will ultimately accept the inhumen warfare and oceupation and wants to turn Afghanistan into compleseiy dependent atelitire state of the Soviet Union. Afghenisesn, it ys, may be regarded as a mea sure of the Soviet Union's commit. went to desenta and world peace. Condemaing the many the Soviets, including the deporta. sion of 50.000 Afghans to the Soviet Union for indoctrination the descruetion of villages and havesta, the use of burzerfly bortas, whose principal victins were children, the resols. tion calls among other things for:

(A) Increaving community food aid tor the Afghan refugees:

(B) The provision of 15 million ecus (European Commusiry currency roughly dollar 17 million) to private ald organiations for the recruitment of doctors and medical reaff and the purchase of medicines and medical care.

(C) The stepping up of material and tirancis aid from the community and the member states to Pariotan to alleriate the burden imposed by the presence of 35 million $A$ fghan refugees.

(D) The members of the EEC io increase the food aid for the Afginan rafugees and to increase thaterial and turanceal 200 to Pakiatsh.

The resolution also calls for national reconsiliation ialks to achlevs a ceasefir: in the near furure and reates that only a free and democratically elected goversmear in Xabul could provide. lesting xolution of the Afghanistan problem.

The European Parimment has pased a number of resolutions in the past on the siruation in Afghan istan but thin year the resolution has boen far more detailed and iar more explicit in its condempacion of the Soviet action and in its recommendatioas of specific meacures to alleviate the plethe of the Afgh an people. 


\section{DR NAJIBULLAH TAL'S TO 'THE MUSLIM'}

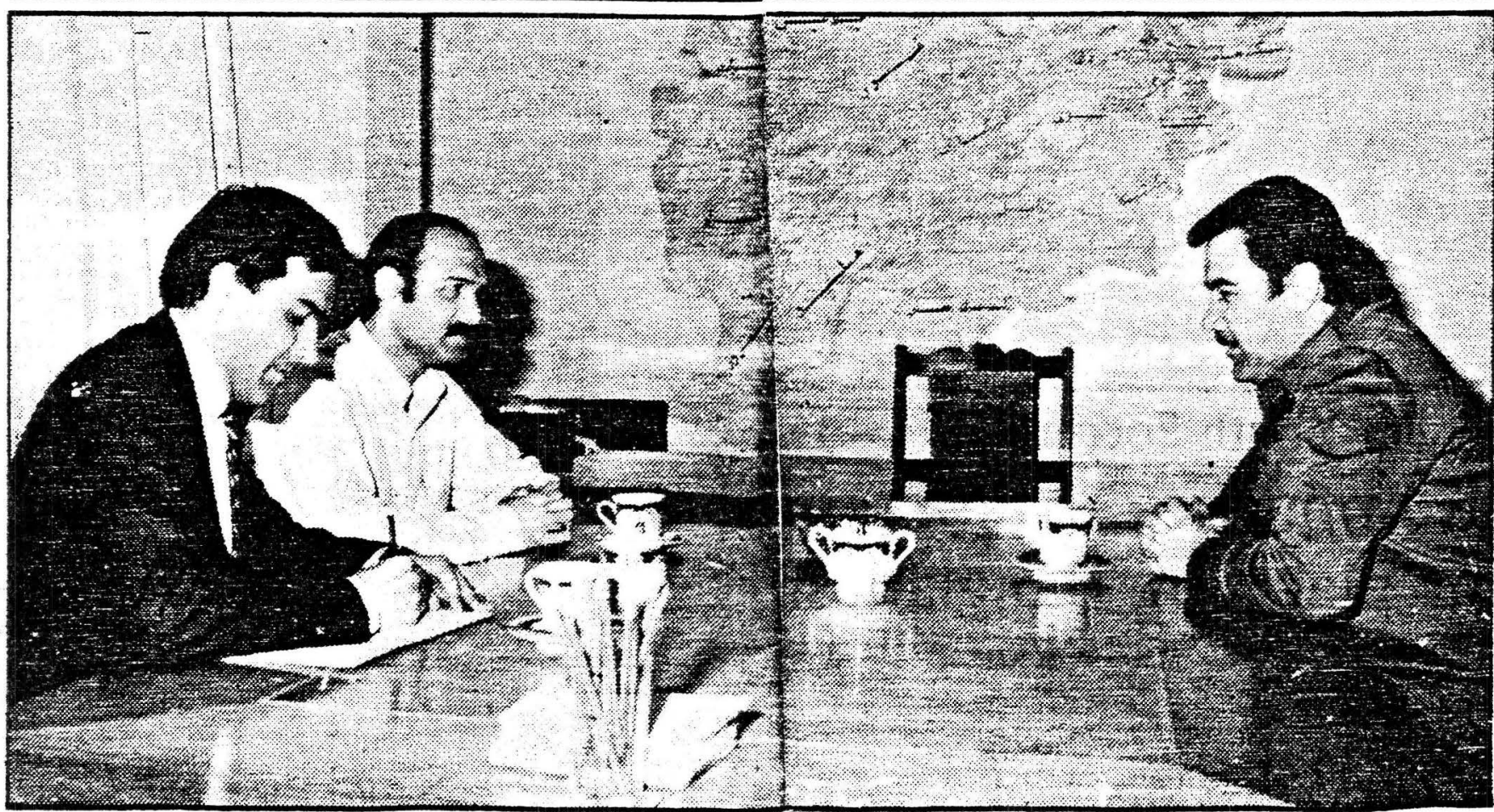

In his firstever interview with a journalist from the Third Worldifghanistan ruling party's new chief, Dr. Nä̈bullah, talks to Mushahid Hussain Sayed, Editor of The Muslim in Kabul of uly 7.

ISLAMABAD, July $8:$ in a wide-ranging interview in Kabul, his first with a journalist from the Third World, the Afghan ruling party's new chief, $\mathrm{Dr}_{\mathrm{r}}$ Najibullah, has made a strong plea for national reconciliation saying. "We are prepared to talk to those who are in the opposition with 2 n open political heart". As if to emphasise this message of mode ration the 39-year old medical doctor turned Marxist formeriy chief of the Afghan secret police KHAD said that "with flexibility we are ready for reasonable compromises". He also promised national elections in Afghanistan "within six months for the democratisation of political life".

The 40-minute interview, part of which was in the form of written answers to questions submitted in advance, took place in the Afghan Capital on the evening of July 7 at Dr Najibullah's second floor office in the Peoples Democratic Party's Central Committee headquarters. The interview formed part of a two day visit to Kabul - the second by this journaiist in nine months. Dr Najib's greeting in Urdu was in a heavy Pakhtoon accent: Kiya haal hain Khairiat say hain (How are you I hope you are well).

Sporting a khaki-coloured safari suit resembling the uniform worn by guerilia commanders, the tall heavy set Pakhtoon from the Ahmadzai tribe of the Powindahs which straddles the Pak.Afghan border answered questions in a calm, relaxed manner. Occasionally interruping to correct his interpreter, Najib. looks more handsome than his photographs make him out to be. His cleat fair complexioned face with sharp expressive eyes is fined by a neatiy trimmed moustache and frequent faint smiles.

He spoke across a small table in a sparsely furnished medium sized functional office which had a few books and pamphlets lined in one corner While there was an impression of not much security around him Najib sipped green tez underneath a portrait of his predecessor Babrak Karmal During the entire conversation. Dr Najibuliah made only a passing reference to Karmal Najib however declined to answer a question regarding the women s demonstrations allegedly in support of Babrak Karmai that took place in Kabul following the Latters ouster in May. While repeating the official version of "health reasons" for Karmal's exit from the top Party slot Najib also said that this move 'strengthened the principle of collective leadersnip' a tacit admission of its absence under Karmal who also flaunted a cult of personality.

During the interview, Najib/who is "Comrade Doctor" to his senior party colleagues) went further than any other Afghan leader in extend ing an offer of talks to his regime's opposition although he was careful to draw a distinction between the Mujahideen leaders (who he said were "traitors") and their followers (the "deceived ones"). There was also the familiar list of accusations against the "Famous Four" - United States Pakistan Iran and China - the Latter accused of supplying $\$ 200$ million annually in arms to the Mujahideen Pakistan he said was sending into his country 50,000 armed guerillas every year.
The interview reflects the more business like approach of the new Afghan leader with an accent on national reconciliation and flexibility in poticy. There were indications in the Afghan capital of changes in the offing in the Party hier aschy via consolidation of Najib's position and weakening of the group around Karmal who has apparently been reduced to a fugure head,

Excerpts from the Najib interview:

Dr N: Weicome once gain to Afghanistan, I know about the interview which you had with Comrade Babrak Karmal hast year. We are aware about the eredibility and prestige enjoyed by "The Musim". We also know the personal efforts made in this connection by you.

MH: I thank you for receiving me at short notice. Let me assure you that, as in the past, we will report the facts correctly, while giving our own perspective on the situation.

MH: Why was the change of your Party General Secretary necessary. Was it due to:

(a) the party's failure to broaden its social base among the Afghan poople.

(b) infighting or policy disagreements in the party or (c) personal factors.

Dr N: The 18th Plenum of our Party's Central Committee approved the proposal of Comrade Babrak Karmal to trelieve him from the post of Generai Secretary due to health reasons. Taking into consideration the accumulation of the sasks of Party and State leadership in the present conditions of the country, a decision wa made on the division of the duries of the General Secretary of the Party and President of the Revolutionary Couneil.

The resolutions of the 18th Plenum of the Party Cen tral Committee further the process of strengthening the principle of collective leadership and is of principied impor ince in the completion of party and state structure. These are the genuine reasons for the decision.

MH: Has your Party's attitude towards the opposition changed? Will it consider talking to those sections of the Mujahideen fuhting inside Afghaniston, who are not linked to foreign powers? I N : In th the resolutions of the plenums of the Central Commi- 
ttee of the PDPA, ingluding its 16th plenum, in which the tenpoint theses approved by the Revolutionary Council were endorsed. These resolutions clarify the issues pertainisg to ensuring country. wide peace, carrying out the policy of national reconciliztion towards those who, due to the propaganda of reaction and imperialism have raken positions against the revolurionary power. The financial and arms aid of the imperialist camp, and complete dependency of ting leaders of bands on them, have played a key roie in organising, managing and leading the activities of all counter-revolutionary bands that take hostile positions towards our revolution. Therefore, the ring leaders of these treacherous bands are traitors to the national interest and in the framework of the undeclared war, are commitring horrible crimes against our people and homeland every day but they apparently deny any relations with foreign countries.

All details of the undeclared wat against our country people and revolution have been engineered by imperialism and its lackeys in the region, particularly the militarist regime of islamabad. We shall approach with mercy, kindness and reconciliation those who have unconaciously stood in the ranks of the counter-revolution i.e., the deceived ones.

MH: What is the significange of the forthcoming plenum, the 19 th one, I believe, of your Party?

Dr N: There was the $18 \mathrm{th}$ Plenum of the Party, there will be the 19 th one very soon, and there will be the 20th Plenum. These are periodic features of any Party's activisy and they contribute to strengthening our work. Apart from other areas, two important points will be discussed at the 19 th Plenum. One pertains to the ponts Theses of the Revolutionary Council announced last November on the need to broaden the political and socul base of revolutionary power. Already local elections are in progress in Afghanistan. These will solidify the state structure. The other major point for discussion at the 19th Plenum is that of national reconciliation. We feel that new facts, realities and potentials have emerged of hate, even among the opposition( Then raising his hands, 28 if in an embrace) We are prepared to talk to those in the opposition with an open political heart. We approach these matters with flexibility and we are ready for reasonable compromises. But this offer should not be seen as a sign of weakness. We negotiate from a position of strength.

MH: Are you even prepared to talk to Mujahideen leaders like Gulbadin Hikmatyar and Burhanuddin Rabbani?

Dr N: (Smilingly) Well, for the se of saving the world from a nuclear war, even Ronald Reagan can make efforts!

MH: Is the PDPA fully united bohind your leadership? Or are there still remnants of the Khalq-Parcham conflict?

Dr N: The inner-party disputes which you mention beiong to the past and are lessons for our party. We hope and have firm conviction that such a tragedy will never be repeated.

MH: How do you assess the possibility of progress at the forthcoming Genews talks beginning July 30? What are the main hurdles, in concrete terms, in Instrument $I V$; in your apinion?

UT $N$. Regarding the progress to be achieved in the forthcoming Geneva talks, it should be expressed that, as we have participated in the previous rounds, pursuing a principled policy based on political determination, goodwill and recessary flexibility, we will maintain this constructive stand of ours in future notiations as well. The fact that what will be the outcome of the forthcoming talks depends on the other side. ( $\mathrm{Pakistan}$ ) If the other side alsc acts in harmony with the will and interests of its peopie, and adopts 2 similar stand, then there will, certainly, be the possibility of progreas.

In view of the existing understanding between the parties in the talks. I cannot elaborate on these in detail, but it can be said in general that there atill exist some points that have to be worked out and finalised.

MH: According to $m y$ information, there are two major points of difference still remaining: The question of time table of withdrawal of foreign forces from Afghanistan and the question of monitoring and verification of withdmal. Could you outline your country's positions on these two points? there are still unoolved points in negotiations. The issue pertaining to the return of the limited contingent of Soviet troops is one such issue. But it must be pointed out here that all the matters undet discussion are inter-reiated and should be resolved in the form of a package. Regarding the other part of your question, due to the reasons that i have pointed cut earlier. I cannot provide an answer.

MH: Would you be willing to shorten the time frame of withdrawal of foreign forces which your side gave at Geneva? As you know, Afghanistan gave a time-table for 4 years while Pakistan insists on 6 months. Would you be willing to shorten it to, say, 12 or 18 months instead of 4 years.

Dr N: Concerning the time-frame of the withdrawal of the limited contingent of the Soviet Union which is a matter exclusively belonging to Afghanistan and the Sviet Union, we have achieved agreement with that country. In setting the time-frame for the withdrawal of this contingent we have taken into consideration the supreme national interest and objective conditions inside and around Afgha nistan and we are participating in the negotiations on the basis of such a stand. The speculation being disseminated in this regard cannot affect our decisions in connection with this issue.

Furthermore, it should be mentioned that as it is ciearly stated in the woll-known statement of August 24.1981 of our government, the securing of complere and reliable cessation of armed and any other intervention in the domestic affairs of Afghanistan and the creation of conditions making impossible the recurrence of such interference in future must be the

main aim and basic content of the political settlement.

MH: Is your governmental structure strong enough to sur vive withdrawal of Soviet forces from Afghanistan?

Dr N: You are well aware that the April Revolution in the first days masses, as well as encountered the hostile reaction of the reaction ary and imperialist circles and forces.

The undeclared was, headed by US imperialism, is waged with its ever broader dimensions against our country. As a result of the unbridled and growing aggression and interference bunched by reaction and imperialism, the independence, sovereignty and territorial integrity of our country are subjected to serious threat.

We have frequently proclaimed that whenever this aggression and interference in the internal a ffairs of our country ceases and its non-recurrence is internationally guaranteed the limited Soviet con tingent will return to that peaceful country.

I can assure you that our revolutionary power is able to exterminate, at the earliest, the savage and isolated counter revolution inside the country and establish nation-wide peace and security in Afghanistan. Because - and one must pay attention to this - the April revolution has triumphed with the inviolable will of the work. ing measses and it expresses the vital interests of the whole working people of our country.

The revolutionary power is increasingly strengthened by our working people's solidarity with and their vigorous, unsparing and dedicated participation in it, its potentiality to defend the indepen dence, natianal sovereignty, territorial integrity of the country and the achievements of the April Revolution is being eve sntianced

We firmly believe in our peopie's victory. The counter-revolution will not be able to, even for one day, continue its disgraceful life without the help of reaction and imperialism.

MH: What is the purpate of national elections, recently announoed by you?

DrN: These are for the purpose of promoting the democratisation of Afghanistan's political iife.

MH: When will these be held?

Di N: Within 6 months.

MH: If diplomatic recognition is granted by some states to the Mujahideen, will it affect your attitude to a jeolitical settlement at Geneva?

Dr N: The de jure state of the Democratic Republic of Afghanistan has already been recogrised by many countries of the worid, includ. ing those that you think may recognise the counter-revolutionaries in the future. If from amors them one or two countries change their previous stand in this respect, they will not only jeopardize their prestige in international arena but will act in contradiction with their position that they have adopted in Geneva talks on the situation around Afghanistan. It should be mentioned that in the talks our side has already presented clearly its stand in this regard.

MH: Assuming, for a moment, that there is no progress at the resumed Geneva VII talks on July 30, would you be willing for a change in format similar to the one that was there at the Paris peace talks on Vietnam? In other words, there would be four parties sitting face to face: Pakistan, Afghanistan. Soviet linion and representatives of those Mujahideen who are fighting inside Afghanistan, without being 'wired' to outside forces.

Dr $N$ : Raising his right hand with straightened palm in vertical position, for emphasis Esteemed Mushahid Hussain Sayed! Let me state very decisively and emphatically: We refuse to have the counter-revolution treated on a par with the Revolution. We refuse to accept that the counter-revolution has any base in Afghanistan except the sustenance it gets from outside via Pakistan. Every year 
50,000 trained bandits are being sent into Afghanistan from

Pakistan. Just similar to what Pakistan is doing to support the "Khalistan Movement" in India. For eign support to counter revolu tion is like oxygen to tham. The $\mathrm{m}_{2}$ in purpose of the Geneva talks is to ensure that aggession and interference againat Afghanistan ceases. If the character of the Geneva talks is changed, other than to ensure that aggiession and interference ceases in Afghanistan, we will oppose it.

MH: What is the degree and depth of Iranian support for the insurgency in Afghanistan?

Dr. N: Breaching all internationally established norms and principles, the medieval regime of the Iranian theologians nakedly and ples. the medieval regint interferes in the internal affairs of our county and virtually makes it an accessory to the undeclared war of country and vertion and imperialism launched against our country. inter mational reaction an borne out by the recent meeting of the Iranian President with a number of Af ghan counter-revolutionary ring leaders. a meeting ordered by A yarullah Khomeini.

The medieval regime of Iran spares no effort to export criminal counter-revolutionary bandits for carrying out sabotage in our county, for killing the working Muslim people of Afghaniscourt the so-called "Islamic Revolu. tan, "and co our country. All such hysteric deeds of the regime of Iran, far from being linked with the demands and will of our worline Iranian brothers, are contrary to them.

We are sure that the day will come, when the working and opressed people of Iran will vanquish the band of mecieval theolo. gians and the obstacles creaced in the way of good-neighbourliness gians and the obstacion of two brother Muslim peoples of Afghanisan and Iran will be removed.

MH: How do you see China's role regarding Afghanistan?

Dr. N: In the undeclared war of reaction and imperialism against the DRA, there exists a black and horribie collusion between the USA, its loval hirelings and Peking chauvinism.

The renegade leadership of China plays one of the main roles in this dirty war against our people and revolution. There exist military caining comps in the Sinkiang province of China where the Afgan counter-revolutionaries recerve training conducted by ChiAfghan counter-revoluiped with Chinese weapons, they are sent to nese instructors. Equipped with Ching horror, destructive activities and killing of innocent people.

The mass media of China, in unison with other reactionary and imperialist mass media, takes an active part in the psychological war. The conditions are the same in diplomatic spheres.

Chinese renegades render all-out assistance to the counter revolutionary bandits entrenched in Pakistan. conduct military training, arm and equip them. By sending them into our country, they practically take part in slaying innocent people, destroying they practically establishments and piundering the property of the people.

The total military aid of China to the counter-revolutionary a its pakistani soil exceeds $\$ 200$ million (annually).

MH: There is a vieu in Pakistan that Afghanistan is keenly promoting moves for merger of Left parties in Pakistan under Wali Khan's leadership. Is this view correct?

Dr. N: The foreign policy of Afgranistan is based on non-interferen$c e$ in the internal affairs of other countries, peaceful coexistence and is aimed at establishing good-neighbourly relations existence al cooperation in all spheres with all countries, especially the neighbouring countries. As far as the activities of political parties of Pakistan are concerned. it should be stated that it is par tes of

$M H^{2}$ : At one time Kabul was headquarters for the Pakistani terrorist group, Al-Zulfikar. What is the position now? Has - your attitude towards Al-Zulfikar changed?

Dr. N: Afghanistan has never been a centre of any terrorist or $g$ niion and will never be so in the future. We condemn all types and sation and wil never be so in the future. We condemn all to pesserve all inter naforms norms and conventions aimed at preventirg and strugging gainst them.

MH: People in Pakistan say being a Pakhtoon and former chief of Khad, you will pursue a harder line towards our country. Already we are daily witnessing bomb blasts in Pesnawa and other areas of NWFP, which are attributed to Khad agents. Your comanienis uri this?

D. We act on the basis of the principle of non-interference in the internal affars of other countries and are loyal to it Social prothe incernal affel censions which oresentiy continue in Pakistan are cess and unterna tensions which presenty conkinc in Pakistan are Ill due to inner factors and motives of the Pakistani society. The development of the situation is clear not only to us but to the whole warld and efforts to find the reasons of this situation outside the rerritory of pakistan are to deceive the world and no one will believe them.
You know better that the city of Peshawar and its vicinity have been transformed into a black market for arms in the undeclared war against the DRA. Peshawar today is the centre guiding the raining and arming of the Afghan counter-revolutionary bands which leads to the increasing loss of control of the military regime of Islamabad over the simation there. The military circles of Pakistan are unconsciously launching efforts to take advantage of the fire that they have themselves lit, by misusing the name of the so-called Khad agents. We have no doubt that such efforts will lead to the burning of their own fingers.

$M H$ : What is your opinion of the so-called 'Pakhtunistan Question?' Is it still an issue today?

D. N: The issue that you have pointed out is related to the Pashtoons so it is upto them to decide as they wish. But in view of long taditional, cultural, religious, linguistic, historic, relations existing between us and our Pashtoon and Baluch brothers, we have persistently expressed our solidarity with them and will do so.

MH: Do you think Pakistan is sincere in its desire for a political settlement in Afghanistan?

Dr. N: The Pakistani authorities have expressed their wishes for a political solurion of the situation around Afghanistan, but there exists a big gap between expression of good wishes and its deeds. The political actions of the Pakistani side in this regard, are the best criterion for our judgement. Therefore, we have to wait and judge crice light of its furure deeds.

MH: Can you list some mistakes made by the regimes in Afghanistan since April 1978? In light of this, are you revising or reversing some previous policies? In which areas would this be?

7. N: Before the new and evolutionary phase of the Revolution, a series of mistakes and deviations took place in the vital and key points of revolutionary process, such as the implementation of land reforms, the approach to culture and beliefs of people, observance of party norms and democratic bases in the society and the recogn: tion of the stage of social development and the tasks of the

National-Democratic Revolution. However, after the victory of the new and evolutionary phase of the Revolution, the revolutionary power has not only corrected the past mistakes step by step, but also, through issuing special resolutions and enforcing laws, worked out the implementation of national democratic tasks based on the realities of Afghan society. All these casks have been fulfilled one after another. The PDPA acts based on the special characteristics of the national democratic April Revolution and the prevailing realities of the Afghan society, and objectiveiy approaches the fulfilment of the undelayable tasks of the Party in the present phase.

IH: What are the 3 or 4 major priorities of your regime?

r. N: The main problems that one has to give preference to in the present situation are: to ensure peace in the country, decisively crush the last bands of counter-revolutionary exported from abroad, peacefully solve the situation created around Afghanistan, and put an end to the undeclared war being waged against our country.

To reliabiy secure the frontiers of Afghanistan and reinforce

and consolidate the armed forces of the country is an urgent task whose fulfilment will provide favourable conditions for peaceful work of our people. Our priority asks are to solve the national question, accomplish a cultural revolution, fully realise the programme of land and water reforms, democratise the social fabric, and translate into practice the first five-year pian after the revolution, i.e. the main aspects of the socio-economic development of our county for 1986.1990. The full suength of the party, state and social organisations is mobilised to attain these goals.

1H: How do you see the US role in Afghanistan?

T. N: If we are to tell completely the satanic, interventionist and aggressive role played by the war-mongering US imperialism as the

chicf suppressive and exploiting force of world reaction and imper. ialism against our homeland and people before and after the April Revolution, it would take a long time.

Today, US imperialism as the organiser of the undeclared war, is chiefly responsible for the bestial killing of thousands of Afghan chidren and elders, the most savage crimes and in a medieval manner, the desuriction and terrorism committed by the mercenary counter-revolutionary bands. The mercenary counter-revolutionary bands have so far received more than two billion US dollars for taining and equipping the slayers with most up to date terroristic and mass destruction arms.

Now, US imperialism, embodied in the criminal and adven turistic Reaga Administration which has made terrorism its official state policy, is openly and shamelessly proud of these barbaric deeds which it commits against the revolutionary people of Afghanistan.

The main aim of US imperialism, in continuing the undeclared war aganst our country, is to creace obstacles to the path of realisation of basic socioeconomic deveiopment, which constitutes the main objective of our revolution. 
MH: Mease tell our readers about your 'Pakistan Connectrion?'

Dr. N: I have been to several piaces in Pakistan: Isiamabad, Karachi, Lahore, Pindi and Peshawar. I speak and understand a little Urdu. I have some knowledge of Pakistani politics but, obviously, I $2 \mathrm{~m}$ not in a position to discuss with you. I used to go to Pakistan because my father was posted in Peshawar. I went there during my school

Mays in the 60s and in the 70 s as well, when I was in the University.
: Thank you for the interview.

Dr. N: Please convey my good wishes and solidarity to the peopie of Pakistan. The people of Pakistan and Afghanistan share common aspirations for a better life. The friends and enemies of the Pakistani

people are also friends and enemies of the Afghan people. They are the enemies of peace, progess, democracy, milicarism. We are optimists As revolutionaries, we hope that, out of darkness, a clear bright future will emerge.

\section{By MUSHAHID HUSSAIN THE MUSTIM JULY 9,1986}

Comrade Najib Talks About Himself

"He said he was born in a building adjoining the present headquarters of the PDPA CC. Presently he is living in the Macrorayon area of Kabul, the abode of workers, craftsmen \& other ordinary people. He obtained membership in the PDPA in 1965... He is very pleased that as the Gen'1 Sec'y of the PDPA CC he can now serve the whole Afghan nation. Najib... is 39 years old, married to a woman teacher \& has 3 daughters." (BIA 7/20)

\section{RUSSIAN SHOT ENTERING SPINZAR HOTEL}

LONDON, July 19: The urban guerilla Mujahideen in Kabul injured an important Russian communist propagandist Oblov when he was going to Spinzar hotel to attend a function. He was shot from a close range. The incident took place on June 30 , when he was getting down a vehicle to enter the Spinzar hotel.

According to the reports received by the Agency Afghan Press, the Soviet propagandist received wounds on his arm and was rushed to the hospital while the function being organised by Khad intelligence department was put off for some other date.

Oblov gained importance when he choosed to live in Kabul in King Zahir Shah era hiring a house in Karta Jeh. He learnt the Persian language to undertake propagatio for communism in the country. It is thought that he was among the persons through whose communism spread in Afghanistan and consequently the Soviets had an opportunity to capture the country. Oblov is reported to have been included $\mathrm{i}$

SOME STATISTICS from Verein Für Afghanische Flüchtlingshilfe E.V. (Aid for Afghan Refugees) in Bonn:

number of civilian war victims: $1 \mathrm{~m}$ mujahideen killed: ca. 80,000 internal refugees: ca. $2 \mathrm{~m}$ refugees in Pakistan: ca. $3.8 \mathrm{~m}$ refugees in Iran: ca. $2 \mathrm{~m}$ refugees in Western countries: 40,000 missing, presumed dead: 45,000 estimated executed in DRA: 100,000 imprisoned in DRA: 65,000

\section{THE MYSTERY OF THE DISAPPEARING CONSUL}

\section{FROM IQBAL MIRZA}

KARACHI, June 30: The officials of the Afghan ConsulateGeneral here are endeavouring to twist the events relating to the defection of their First Secretary and Acting Consul-General, Mr. Baz Mohammad Rahyab, on the night between June 25 and 26 , according to reliable information available here today.

Mr. Ghulam Hassan, ViceConsul and Second Secretary at the Afghan Consulate here, who briefed newsmen about the incident, put out arguments which were not convincing at all and looked like a "cock and bull" story aimed at confusing the situation.

For instance, his assertion that Mr. Baz Mohammad was kidnapped by Mr. Graham, Vice-Consul at the U.S. Consulate here who, according to him' is an under-cover CIA agent, does not sound very convincing as according to a well connected source there is nobody working as ViceConsul by the name of Graham at the U.S. Consulate General here.

It also looked mysterious that the Afghan Consulate here reported the matter to the police after waiting for five days. Police registered a case under Section 363 PPC yesterday on a complaint that $\mathrm{Mr}$. Baz
Mohammad, his wife and fourmonth old daughter were missing and possibly have been kidnapped. While mystry shrouded the disappearance of $\mathrm{Mr}$. Baz Mohammad and his family, a spokesman of the Afghan Consulate was quoted here having told an eveninger that Mr. Rahyab was very friendly with a French lady who was working as Secretary at the Consulate. It was possible that the French lady was aiso with him when the went to sell his car at the Belgian consulate.

Mr. Rahyab was a very active diplomat in the city and was often seen in the company of Russian diplomats here.

The pre-mature transfer orders asking him report back home immediately gives weight to reports that he was not happy with the policies being persued by the Afghan regime. His disillusionment must have been conveyed to Kabul and ultimately resulted in his call-back orders, it is assumed.

Police, however, have so far found no trace of the missing Afghan diplomat and his family here. It is most likely that he has defected to seek political asylum in some third country. $\quad \mathrm{p}_{\mathrm{T}} 7 / 1$ the negotiating team which concluded the 21-year agreement with Kabul duri- g King Zahir regime. It is also reported that he was related to the former Soviet President Brezhnev and was described as first man of the Soviet Union for his role in Afghanistan. PT $7 / 20$

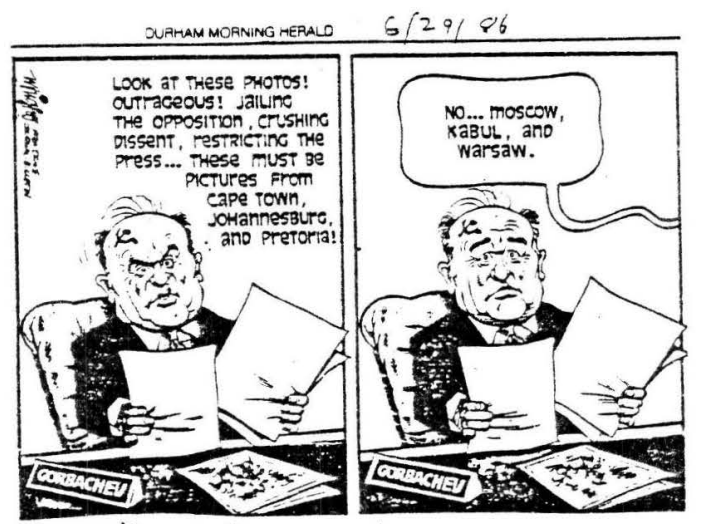




\section{By WILLIAM J. EATON}

KABUL, Afghanistan - Najib, the new one-named leader of Afghanistan, has a reputation for being tough, efficient and expert at infighting with rivals in his party.

He is 38 , a big man, built like a football linebacker, with black hair, a carefully trimmed black mustache and dark, flashing eyes.

He has taken a hard line against the anti-Communist rebels, demanding additional sacrifices from his people in pursuit of a military victory that he admits may take years to achieve.

By building up the Afghan army, depleted by desertions, he may help make it possible for Moscow to withdraw some of the estimated 120,000 troops it has here.

In a recent interview, Najib expressed confidence that the rebels - he calls them "bandits" - are losing the ability to mount a major attack. And he dismissed U.S. President Ronald Reagan's renewed vow of support for the rebels as a "political farce" to conceal their military weakness.

Before taking over as the national leader, Najib was head of the Khad, the Afghan secret police. In that post he was able to plant spies among the insurgents and to persuade or bribe Pushtun tribes to block rebels from penetrating into Afghanistan from Pakistan. He worked closely with the KGB, the Soviet security service, to build the Khad into a widely feared force.

\section{'God's Nobleman'}

Originally, his name was Najibullah, which translates roughly as God's Nobleman. Since taking over as general secretary of the party, he has shortened it to Najib. During the party plenum at which he was picked to replace Babrak Karmal, the 57-year-old revolutionary who fell into disfavor with the Kremlin. Soviet tanks and troops surrounded key government and party headquarters here.

Kabul radio said the change was made because of Karmal's bad health, but the handover had more of the flavor of a coup d'état.

This impression was strengthened, according to Western diplomats here, by demonstrating high school students, who chanted slogans for Karmal and against Najib. Police dispersed them.

The official announcement said Karmal resigned for health reasons, and emphasized that he will retain his ceremonial post as president of the Revolutionary Council and membership in the Politburo; it did not mention illness.

Unlike the Kabul-born, Persianspeaking Karmal, Najib is a Pashtun, a member of the biggest tribal group in the country. He grew up on the frontier with Pakistan, not far from the legendary Khyber Pass.

Najib attended the English-language Habibia College in Kabul and entered the medical college of the University of Kabul. At the university, according to Western sources, he spent most of his time in revolutionary agitation, and it took him 11 years instead of the usual six years to complete his studies.

As a university student, he joined the People's Democratic Party, and when it split into two factions he became a member of the Parchami faction led by Karmal. As the university spokesman for the Parchamis, he became a leading opponent of the rival Khalq faction, according to Afghan exile sources.

Najib had no direct part in the 1978 revolution that brought the People's Democratic Party to power. It was led by Nur Mohammad Taraki and Hafizullah Amin, but Taraki was assassinated in 1979 and Amin was killed when Soviet troops landed in the capital not long afterward.

Karmal was flown in from Moscow and installed as leader, triggering widespread resistance from Muslim fundamentalists who opposed the change. Najib reportedly arrived in Kabul on a Soviet plane five days after Karmal and was made director of the Khad.

Before long, open hostility developed between Najib and Gen. Sayed Mohammad Gulabzoi, head of the Interior Ministry. Agents of the Khad and the ministry harassed and tortured and killed each other, according to Western diplomats.

Najib, who began to play a more powerful role in the war effort, was shifted from the Khad to a secretary of the party last December. A few months later, he was given responsibility over the armed forces, and Karmal became virtually powerless.

It was a considerable turnabout, since Karmal, a founder of the party, has a long record of political struggle against the old Afghan monarchy. In contrast, Najib was practically unknown to most Afghans.

At a recent meeting organized by the National Fatherland Front, a coalition of groups backing the regime, Karmal sat silently while Najib gave a 20-minute lecture on the front's shortcomings. And at the conclusion of the meeting, Karmal was applauded when he embraced the front's president, a warm gesture immediately if awk: wardly imitated by Najib.

In an interview in his offices at the Central Committee of the party, Najib sat under a portrait of Karmal. Asked why his picture had not been put up, he replied, "As long as I am here, there's no need for my photograph."

Elsewhere, however, there may be more concern about photo protocol. An official in an auto repair factory was asked why Karmal's portrait was displayed instead of Najib's next to one of the Soviet leader Mikhail Gorbachev, and he replied: "It will be there. Soon."

- William J. Eaton. the Los Angeles Times' correspondent in Moscow. has been on assignment in Afghanistan.

MONTREAL GAZETTE $7 / 21$ 


\section{KGB Infiltrations}

On The Rise

PARISTAN EXPELS AFHGAN JOURNALJST

Mohammad Hassan Wolasmal, Editor and Publisher of Mujahid Wolas who had been detained by authorities of the Government of Pakistan and spent several months in a Peshawar jail has now been expelled from that country. Mr. Wolasmal has been granted asylum in Norway where he is expected to resume the publication of his newspaper.

At a Press conference in Oslo, Nowary Mr. Wolasmal charged that "most of the best weapons of the Mujahideen are taken by the pakistani military authorities who gives the stored weapons to the freedom fighters, instead; weapons which are impossible to use in the war against the Russians." The allusion being that the modernization of the pakistani weapons takes precedence over the provision of vital military assitance to the Afghan Mujahideen.

He also warned against the infiltration of a growing number of KGB agents in the ranks of Mujahicief as well as in the Pakistani Government bureaucracy. This has led to the killing and disappearance of many Afghans in recent months and it has no doubt jeopardized the security of pakistan along with the future of the people of Afghanistar. Wolasmal adieci that "people in Fakistan who really want the freedom of Afghanistan, are either killed or taken prisoner, or they are compelled to leave Pakistan. For example, Abdul Rahman Pazhwak, Wolasmal, Aziz-u-Rahman Ulfat and two other Afghan journalists, Tahir Muhsini and Shah Zaman Wriz Stanizai, were taken prisoner, and yet nobody knows whether they are alive or dead."

At the oslo press conference Wolasmal also warned against such infiltrations which could affect the resistance of the people of Afghanistan in a negative way. Afghan Mujahideen "commanders whom the Eussians cannot kill with all their Fower in the battlefield, can easily be killed in Pakistan, especially in Peshawar with the help of agents." He gave as an example the names of Commanders Zaman, Haji Rhair Mohammad,
Tore Pacha, Mahboob-e-Elahi and many. others who have been attacked in broad daylight in the city of Peshawar.

Mr. Wolasmal's clajns have beien verified by reporters such as Edward Girardet whose reports in THE CHRISTIAN SCIENCE MONITOR (January 1, 1986) reads: "According to police reports, there has been an average of at least one killing a week since last summer. While some may be the result of political rivalry, the killings are rargely thought to be the work of KHAD, the Afghan secret service, which is active in Peshawar and arnong dissident Pakistani border tribesmen."

The same report alludes to the issue of infiltration and confirms riolasmal's fears that "the number of assasinations against Afghans workjric for the resistance are on the rise." The Afghan Information and Documentation Centre bulletin for the first half of Feburary 1986 reports the following incidents:

* February 3 - one person was killed and 29 injured when a bomb exploded in a bus moving from Sadda, Kurram Agency towaras Tall.

* February 8 - A bomb exploded in the bazaar of Sadda, Kurran Agency. killing one person and injuring 20 others.

* February 9 - As a result of a bomb blast that took place in the office of pak-Libya Holding Company in Karachi, one person was killed and 8 injured.

* February 9 - A bomb blast injureo one person and set ablaze four shops in the cattle market of Miran Shah, North Waziristan Agency.

* February 12 - A tromb blast damaged a house and a vehicle near Garden Town, Lahore.

* February 14 - Three refugees were killed and two others wounded as a result of mine blast in a vehicle in Kurran Agency.

wolasmal, charging the Government of Pakistan with human rights violations, gave an account of his time in jail to the reporters. He accused individuals of torture and said: "In Peshawar Bala Hisar, Military officers like Captain Bashir and colonel zahir mistreated the Afghans and acted against human rights with the help of S.P. Amanullah and other police officers. A freedom fighter, ziaullah Logari, lost his. life under torture by the police in Hayatabad Police station."
A rather toned down $A P$ report in the URBANA NEWS GAZETTE speak of anti-Soviet protesters beaten back in pakistan while protesting the soviet invasion of Afghanistan: "police wielding bamboo clubs and truncheons today beat and arrested hundreds of Afghans who, tried to march on the Soviet Embassy to protest the soviet military intervention in their country six years ago.

"Helmeted riot police armed with shields, clubs and leather strás repeatedly charged and beat the students, herding them away from the embassy. Among those beaten by police as they lay in the street were crippled Afghan guerrilla veterans with artificial legs, who were unable to run."

In regard to the living conditions of refugees in Pakistan, Mr. Wolasmal said that in some cases commissioners have created a state within a state. He held Arabab Dost. Mohammad responsible for such a state of affairs in the Nasir Bagh camp for widows, which he said is like a prison.

A recent report in the Islamic World Review - ARABIA (March 1986) confirms Mr. Wolasmal's concern in saying that: "Leaders of the European aid committees almost without exception considers the Pakistan Welfare International (PWI) idea to be ill-advised." In reference to Abdullah Khan the apointed head of PWI the report says, "many of the Europeans have dealth with Abdullah Khan before and found him difficult to work with, if not openly hostile to the Europeans. Most know him as someone who has occasionally undermined European efforts to aid the Afghans. For those European aid committee representatives who are cautious about the impact of the American commitment and skeptical of the role of PWI, the appointment of Abdullah khan appears to be far from auspicious."

The report is supportive of the European humanitarian committees whose record it claims speaks for itself: "most have attained high levels of efficiency and effectiveness in supplying the Afghans with vital services during the course of the war and can point ot solid results for their efforts." 
We, the free people of Afghoniston in exile, hoving been driven from our homes, lands and estates. and severed from contect with our loved ones and with our loved ones and from our cultural heritoge of Soviet Imperiolism, do nereby, by the grace of God, prociaim to all inhabitants of this pionet. the highest aims of nobiest ideais of the Aighan peoole.

Hoving prayed for the repose of the souls of the ever-growing number of martyrs of this cruelest oppression visited on our people, and for justice an freedom for those still in throll to the odious regime of the puppet government Imposed by the Kremin. we nereby:

CALL UDon potriotic AIghons to unite and dedicate themselves to the -estoration of peace. freedom, nationa reconciliotion and the estoblishment of o government representing a!l the people of our motheriand, afghoniston.

WE further cail upon the world to beor witness to these truths:

TYHAT all the people. throughout the length and breadth of Afghaniston, have risen in opposition to the brutal occupotion and continued depredetions inflicted yoon them by the soviet inuader.

THAT the flogrant soviet invasion and genocidal we in Afhgoniston is conirory to ail the norms of internationat law and civilized behovior, and is in violation of solemn treaties, including the United Natons Chater, of United Notons Chater, or signatory.

THAT the Soviet Union has shown contempt for the decent opinions of monkin as expressed by the General Assembiy of the United Notions, the Organization of the states, and numerous othe nationat and internotional semands for soviet withdrawal from

withdrawsl from
Afghanistan.

THAT whatever the Sovie ob jectives may de in Arghenistan, there can be no justification for their prolonged attempt to destroy the free will of the afghan people by force.

THAT we Afghons are o proud and freedom-loving peopie who value and cherish our independence cherish our indepe ail else.

THAT there is not now o gitimate representation for the afghan people in ony internation at forum, and thet the many needs for heip for the Afghon people in their vallant struggle to be free remain largely unfulfilled.
Therefore, we Afghen patriots, in order to redress these in justices and remedy these deficiencies. to hereby detiore the estoblishment of The Provisional Government of gfghenisten, dediceted to the ochievement or ine following lofty oims: To compel the immediate and total witharawal of all soviet force and personnel from Afghenisten.

TO provide o non-partisan faction-free poilitical institution to serve. representative for ail sections of the Afghen resistance.

To unify all the disporate eiements currently fighting the soviet octupetion into the Soviet occupation into
one united and cohesiue one united and cohesive
command in arghonistan.

I0 re-establish the notionat sovereignty and territorial integrity of Afghaniston.

To create a representative government for the heroic people of Afghaniston.

To preserve the Islomic character ond notional identity of the peopie of Afghanistan.

to advence in nationat 3 nd internotional arenas the interests offingnaiston. To prouide resources for more effective resistance and humanit orian aid for the victims of the wer the victims of the wer
inside and outside inside and outside
afghanistan.

To deveiop support from. and friendly diplamatic relotions with, freedom-toving countries for the purpose of liberating and recons tructing Afghaniston.

To restore Afghanisten's seat in the United Nations and other internationa! bodies to the rightful and legitimate representatives of the people of

Afghenistan.

To foc us wortd opinion and engesider international outroge against the geno:ti al actions of the Soviet linion and its puppet governinent in Afghaniston.

To these objectives we pledge our lives, our fortunes und our sacred honor.

ifistorical Phto of sone of The Founders of the Afghanistan

\author{
Govrenuert In Exile
}

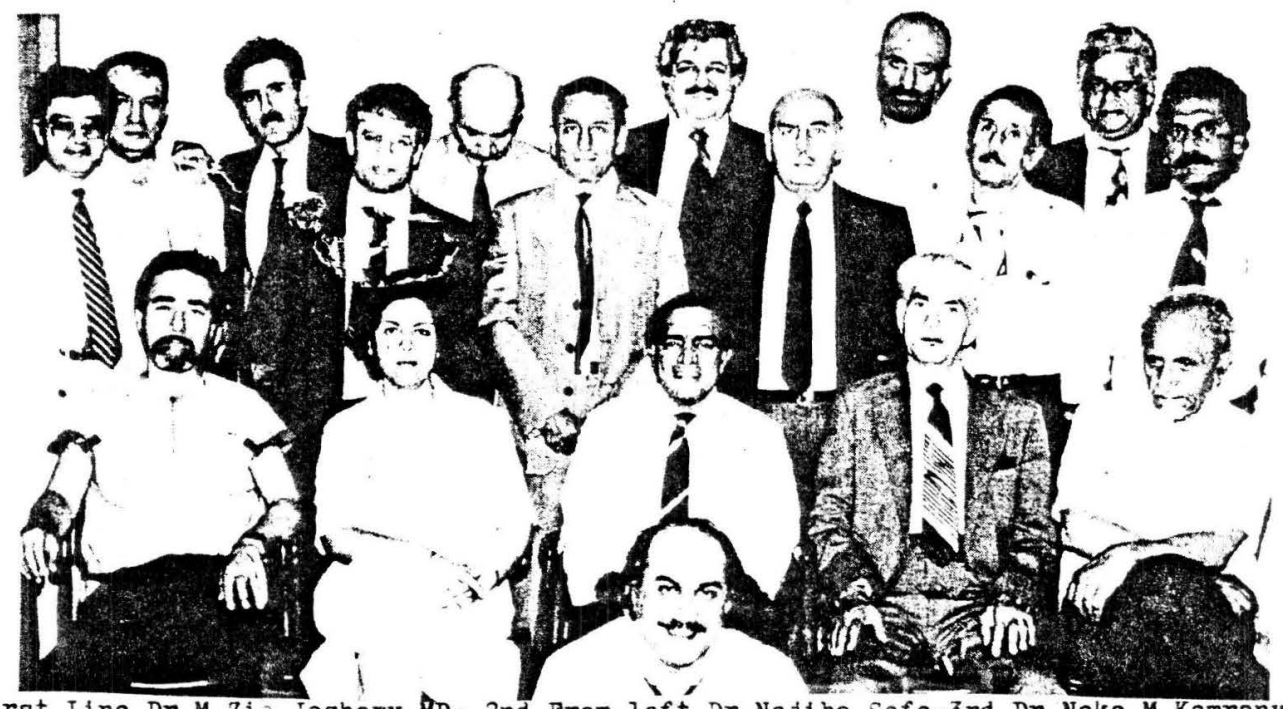

First Line Dr.M.Zi Taghory MD- 2nd From left Dr.Najiba Safe-3rd Dr.Nake M Kamrany sconomist at USC - 4 th M.I.Kandahari Astrologist-5Th H.E.M.Ismaiel Mayar Former Senator \& Governor of Kabul -

2nd Line From Left : Dr. Sayed Shafi Rahil Former Minister of Information \& Press 2nd It.Abdul Salam Satar- 3rd Akmal Ghani Ahmadzai Diplomate- Dr. Ghulam Hassan-Safi Former Governor of Muqur -Pr. Saduddin Shpoon Poet -Engineer Noor U1haq. FreeDom Fighter.Last Line : Dr. A. Wahid Karim Former Afghanistan at Washington- Pr.A Jabar Sabit Lawyer-H.E. A. Ahad Karzai Senatior \& Speaker of The Parliament- Sayd Hussian Shah; Buinessman- M.Habib Mayar Businessman- Sitting up front Knan Zia Khan Nassry Founder of The Afghanistan Foundation \& Afghan News.

\title{
U.S. Will Help Train Afghan
}

Boston University has been awarded a $\$ 180,000$ grant to train Afghan refugees as journalists and King Features Syndicate will receive $\$ 310,000$ to create an Afghan news service, the United States Information Agency has announced.

Senator Gordon J. Humphrey, a New Hampshire Republican, originated the idea, which was approved by Congress in 1985. "The Soviets," Mr. Humphrey says now, "were succeeding in withholding news to the world of that war "u adds that he thinks Afghan journalists can tell the story best but that there are almost no trained ones among the Afghan refugees now in Pakistan.

The U.S.I.A., which was designated by Congress as the agency in charge. had never been actively involved in setting up training programs for journalists, although it frequently sponsors visits to this country by foreign journalists and administers other educational programs such as the awarding of Fulbright Fellowships. It is an independent agency that takes molicy guidance from the State Department.

According to Lesiey M. Vossen, a spokesman for the U.S.I.A., representatives of the university and King Features are in Pakistan negotiating with its Govermment for permission to conduct the programs there, which the agency would srefer.

Early this year, when the oran:

\section{Journalists}

plications were being drafted, the journalism faculty at Boston University was bitteriy divided over whether the training should take place in Pakistan, as was called for in the agency's guidelines. Bernard S. Redmont, dean of the College of Communica tions, and much of the journalism faculty said that the journalism training should take place on the Boston cam-

Their position was based on istical and administrative difficulties in Pakistan and on concern that the program might be considered more a propaganda effort than a journalistic one if it was conducted abroad.

The agency argued that it would be too expensive to bring the prospective Aighan journalists to Boston and that culture shock would disrupt their studies. The proposal from the university was submitted by the provost because Dean Redmont refused to endorse a Pakistan-based training program. Last month Dean Redmont resigned his administrative post. According to peopie close to the situation. who asked not to be identified. the resignation was a result of administrative iriction with the university"s president, John R. Silber, in the Pakistan debate. 


\section{$7 / 12$}

INDURMAR GHAI, Afghanistan (AP) - Peanut butter is not winning the struggle for hearts and stomachs in Afghanistan.

The all-American food, in olivegreen plastic combat ration packs, is reaching Moslem guerrillas fighting the Soviet-backed communist regime. But many of the guerrillas are less than enthusiastic about the foreign delicacy.

"I don't like it. It is not good to my stomach," said a guerrilla named Amarullah.

Dozens of unopened packets of peanut butter from Visalia, Calif., dotted the hillside of the insurgent base here.

It took a while to find a guerrilla who admitted to liking the stuff.

"I like it because it has vitamin A, vitamin $B$, vitamin $C$ and other good things," said a guerrilla named Narullah.

"IT DOES not taste so bad," said the fighter, apparently impressed with the food's nutritive qualities listed on the pack.

Pant of the problem seems to be that no one has explained to the guemillas that peanut butter is better spread on bread than eaten by itself.

The oversight is not unusual. Neither have the rebels been told to add water to dehydrated peaches and fruit salad also supplied in combat packs.

But the guerrillas said that even dry, the peaches from Edinburg, Texas, and the fruit salad from Albany, Ore., tasted a lot better than peanut butter.

The peanut butter and dehydrated fruit, sent by the U.S. government to Afghan refugees in Pakistan, have found their way to the guerrillas, who are fighting Afghan government forces and an estimated 115,000 Soviet troops.

U.S. EMBASSY officials in Pakistan said the supplies are given to the refugees as humanitarian assistance and are not intended for the guerrillas.

The rebels, most of whom cannot read the English on the packs, seemed a little confused about where the peanut butter came from.

"It comes from China," said a guerrilla called Sharah Khan.

"No, Saudi Arabia," said a friend.

\section{BY ARTHUR BONNER}

PESHAWAR, PAKISTAN

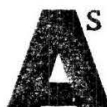
a new Communist leadership in Kabul tries to rebuild the army and gain popular support, the divided Afghan guerrilla movement still seems unable to pull itself together.

The fighting has reportedly been in a lull for months, feeding pessimism about the guerrillas' chances. A year has passed since seven main guerrilla groups based here yielded to pressure from Pakistan and formed an alliance. Yet they still have separate treasuries, enlistment rolls and supply lines. They have yet to fight a battle under unified command.

Meanwhile, under Dr. Najibullah (like many Afghans, he uses only one name), who on May 3 replaced Babrak Karmal as party General Secetary, seasoned Communist officials have been Irafted into the army and politically connected deferments ended. The Soviet Union, which has had combat troops in Afghanistan since December, 1979, has been trying for years to create a creditable surrogate army, to minimize Soviet casualties and involvement. The first fruits were apparent in April, when Communist forces overran a major guerrilla base in Paktia province, near the Pakistan border. Only one of the 13 victorious units was Russian, guerrilla reports say.

Guerrilla activity has declined in recent months, largely because of the disunity, according to journalists and other observers of the war. Although the groups claim more than 200,000 men, only a few thousand are believed to be combatants, and then only intermittently. Thousands sit fully armed for weeks at bases in Pakistan, these observers say.

The guerrillas have not claimed a major initiative for six months. Of the dozen or so isolated battles they report each month, half are in response to enemy attacks. Most of the rest are long-range attacks using ground-to-ground missiles, or harassing attacks on convoys.

\section{Govermment Attacks Limited}

Because Afghanistan is closed to Western journalists, it is impossible to paint an overall picture of the military situation. Even journalists who accompany guerrilla units see only a small part of the country, which is the size of Texas; much depends on rumor and hearsay. Last week, for example, Western diplomats in Pakistan reported that the guerrillas had shot down a transport plane carrying 100 Soviet or Afghan soidiers. As usual, there was no confirmation.

During the same period, Government and Russian initiatives have been limited to strikes against guerrillas in the "sanitized" areas around Kabul and other cities and against their bases and supply lines along the Pakistan border. Most of Afghanistan has been left in peace. "If a mujahedeen [guerrilla] base became a threat they would smash it immediately, no matter what was happening elsewhere," a Pakistan authority said. "They are not attacking now because the mujahedeen are no longer a threat. At the same time they do not want to attack nonmilitary targets. It has been years since the Russians engaged in indiscriminate bombing and attacks. The Communists want to win the support of the peopie or at least neutrailize them."

The Communists also seem to be trying to win over guerrillas weary of more than eight years of war. "Messages are sent to mujahedeen com- manders," said Fazle Akbar, who publishes a semimonthly battle bulletin. "They are told they can keep their guns and even their anti-aircraft weapons. They are told they can hold trials and execute criminals. They are only asked not to attack the cities and Government bases near them or the convoys on the roads." Early this year, Brig. Sarwar Nuristani, who previously defected to the guerrillas, flip-flopped back and became a Government militia commander in southeastern Afghanistan. Last year, another major guerrilla commander, Esmatullah Muslim, joined Government forces in Kandahar Province. A Pakistani who regularly travels to Kabul said he has met many former guerrillas driving taxis or motorcycle rickshaws there. He said Kabul radio regularly broadcasts names of guerrillas who have accepted a longstanding amnesty offer.

In addition, "several hundred former commanders are operating shops or trucks in Peshawar and other places," another Pakistani said. "Some got rich by selling captured weapons.", Many Afghans still insist their nation can never be defeated, that the guerrillas can fight on indefinitely in the mountains.

However, some are wondering whether a tie may be nearly as bad as a loss. "Time is not on the side of the resistance," said Sayed Shamsuddin Majrooh, an Afghan Deputy Prime Minister in the 1960's. "Eventually the people will grow tried. They will turn to the Communists just to get on with living."

\section{Afghan rebels 'selling drugs'}

SAN FRANCISCO: Hashish carrying the insignia of Afghan rebels and stamped "Smoke Russia Away" has started showing up in the San Francisco Bay area, a newspaper reported yesterday.

A Bay area drug dealer told the San Francisco Chronicle that the blocks of Afghanistan hashish were already stamped when they arrived by ship.

The insignia had a drawing of a semiautomatic rifle in the centre and "Afghanistan" written on the bottom.

An agent of the US Drug Enforcement Agency in Washington confirmed that "individual" rebels might be producing and exporting hashish to the United States and other nations, apparently to help their war effort. - Associated Press. SCMP $6 / 3$

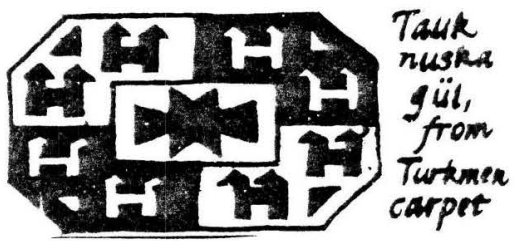


CHANGES IN THE KABUL REGIME

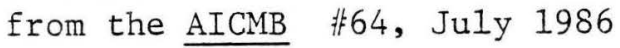

The only concrete result of the recent plenum in Kabul was a large number of new appointments. Some unknown people were appointed and others removed or replaced. Those moved into new positions are all in favor of Dr. Najib, helping him to consolidate his personal power. This recent development is more than a new victory for the Parcham faction over the Khalqis; it is a personal victory for Najib \& his trusted friends.

Some examples:

Assadullah Sarwari, Khalqi, member of the CC, was dismissed. He was the most powerful man under Taraki, heading the state secret police. Assadullah was the first to start the communist regime of cerror: mass arrests, torture, executions. One who has not forgotten his personal experience in Sarwari's tor-. ture house \& the Coca Cola bottle introduced into his rectum is Kishtmand, the present Prime Minister. Prior to $\mathrm{Na}-$ jib's appointment as 1st Sec'y of the Party, there were rumors about Sarwari replacing Karmal. Thus by removing Sarwari, Najib made his enemies (who are many) happy, especially Kishtmand whose Hazara followers form the majority of KHAD. At the same time he eliminated a potential rival who, like himself, was a former chief of the secret police.

Yassin Sadeqi, a Parchami \& close friend $\&$ relative of Babrak, has been dismissed. He was a civilian working in the administration of the fertilizer plant in Mazar. Babrak gave him a military rank $\&$ appointed him political commissar of the Defense Ministry. Najib hopes that Sadeqi's opponents in the Khalq faction would be attracted to him \& that Sadeqi's plotting with Babrak against Najib in the armed forces would stop.

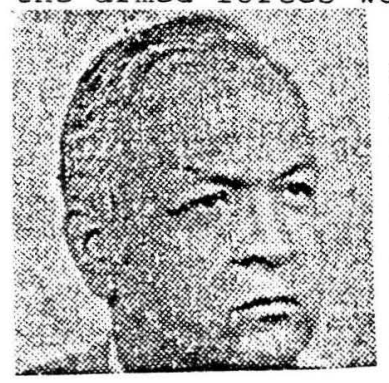

Suleman Laiq, Parchami Minister of Tribes \& Nationalities, has been promoted to full membership in the Politburo. He supported Najib when the latter headed KHAD \& was Party
Sec'y. KHAD \& tribal affairs are now more closely connected.

Farid Mazdak, a Parchami of no importance but an old intimate friend of Najib, was given full membership in the CC.

Contrary to general expectations, Interior Minister Gulabzoi seems to have had his power \& authority further strengthened. Under Babrak his influence was shrinking. Now his ministry is expanding. Security in Kabul, including house-to-house searches up to now the exclusive job of KHAD, has been given to Gulabzoi's ministry. His staff has been much increased. By promoting Gulabzoi, a declared enemy of Karmal, Najib hopes to win the sympathy of Khalqis.

Gen. Khalil, head of the Surveillance Dept. of the Defense Ministry, is reported to have been arrested along with 60 army officers. They are suspected of planning some anti-gov't action. Khalil was involved in Daoud's 1973 coup. He spent a long time in the USSR \& married a Russian girl. Babrak appointed him to the Defense Ministry.

$$
* * *
$$

On June 23rd, Bakhtar reported the following changes:

Moh'd Aziz, former Minister of Light Industries \& Foodstuffs, was appointed Deputy Chmn of the Council of Ministers \& Pres. of the State Planning Committee. Lemar Ahmad Lemar, former Pres. of the State Controlling Committee, is the new Minister of Light Industries \& Foodstuffs. Moh'd Sharif Sharifi, a VP of administrative affairs of the Council of Ministers will be the new Pres. of the State Controlling Committee.

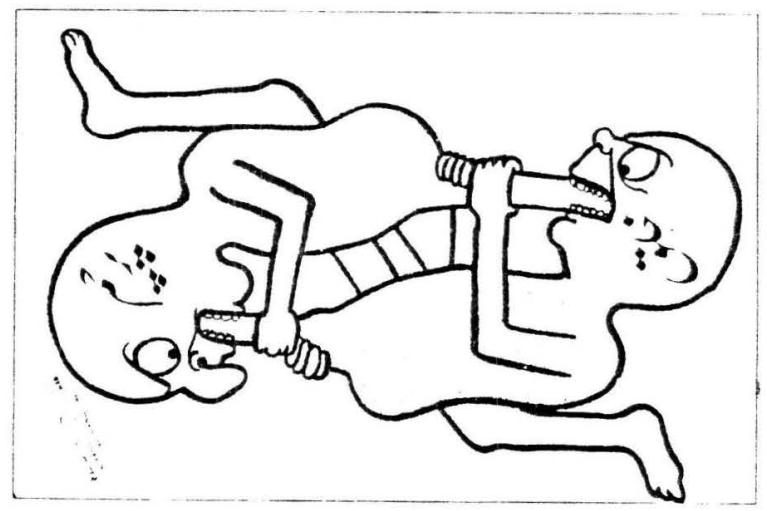

Internal Islamic Front cartoon shows Parcham \& Whalf eating each other's feet. 


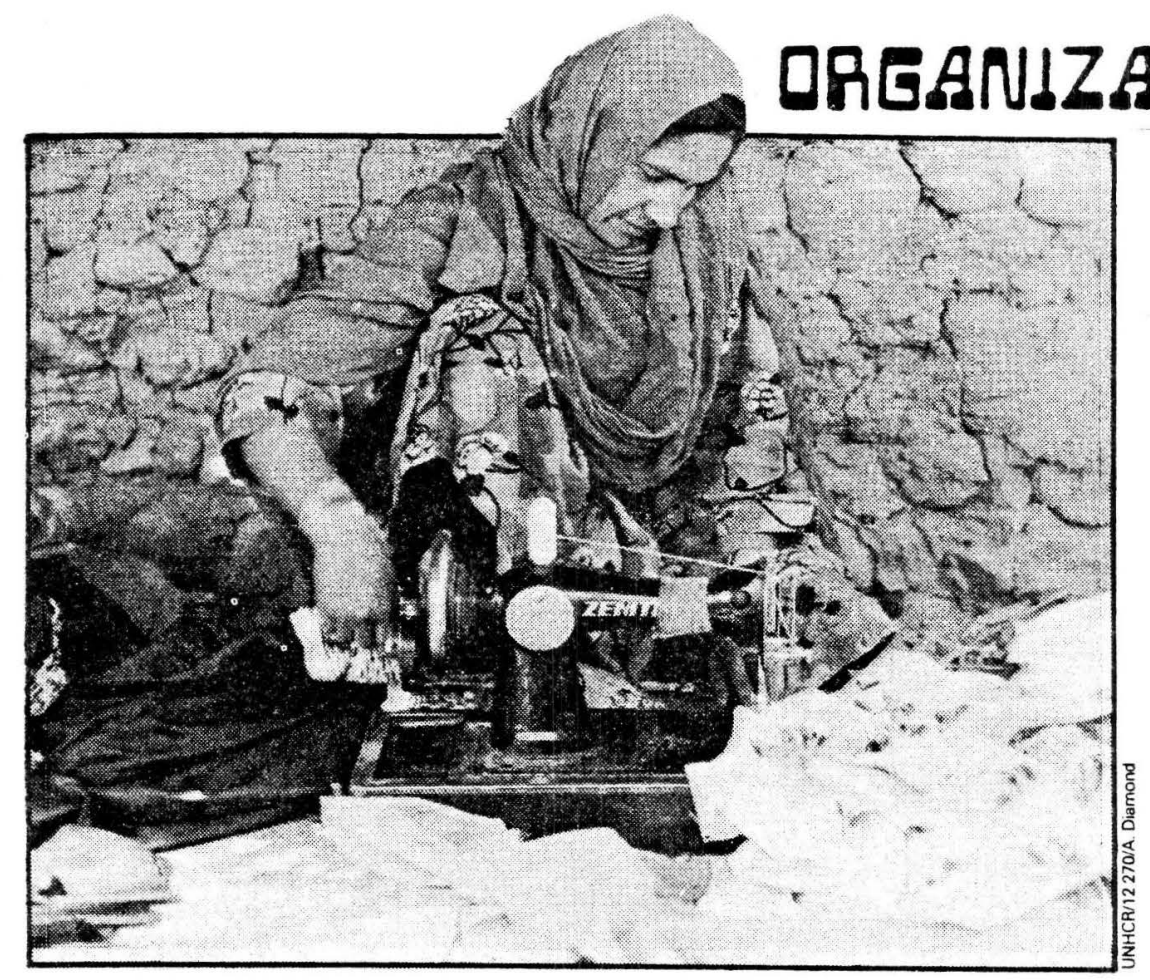

Pakistan

\section{Ockenden Venture projects for Afghan refugee women}

Two members of the Ockenden Venture, a British voluntary agency, Lobsand and Yangchhen Yeshi, recently went to Pakistan as volunteers to help the Afghan refugee women in this country to set up a quilt-making project to provide a small additional income and occupation for those marooned in the camps. They chose to work in Kababian camp, in Peshawar area, where the population is over 19,000 refugees, because it was one of the poorest. Their report:

\footnotetext{
"When we discussed this project with the refugee headmen - 'maliks' - in the camp, we received a good response, after which we chose the site for the construction of the work centre. Then we had meetings with the landlord of the site, with whom we finally agreed that we could use his land and that any construction on it would belong to him at the final return of the refugees to Afghanistan. Then, in co-ordination with UNHCR and the Office of the Chief Commissioner for Afghan Refugees, we started the construction of the
}

work centre in January 1985, and it was completed in August 1985. Meanwhile, we had started work by giving out raw materials for the women to take home. We also bought sewing machines and gave them out to the refugees for which they paid in instalments.

"The first two women we employed were Mascoma and Fatima, both widows and with no source of income. Very soon, more and more people came for work and, as it was difficult for just the two of us to oversee everything, we employed two local staff members to supervise and keep a strict quality control.

"The project has developed very satisfactorily and now in Kababian we have over 100-125 families employed in just doing the quilting. Several other people are employed in sewing quilt bags, and carding the cotton. We give priority to widows and low-income families. The work centre has now been completed and very shortly we will start there with women working in shifts. It will not only be a place to work but a place for them to gather socially. Instructions on child care and primary hygiene will be offered. This project has generated income for many refugees. It is now in the process of expansion from the initial pilot project to a fullscale quilt-making project.

"As we realized that there were more people with sewing skills than we could employ in our quilt project, we started a tailoring project. In April 1985, an order for school uniforms for Afghan refugee students was accepted. Four skilled tailors are employed to cut. The cut uniforms, consisting of a long shirt and baggy trousers, are distributed among semiskilled tailors to sew. This contract for tailoring of school uniforms has been of great help to the many skilled and semi-skilled refugee tailors. Sewing machines are provided, for those who do not have them, on an instalment payment system. We are also making 65,000 school caps, so you can imagine how busy all the sewing machines in Kababian and WarsakMichni are."

At the request of UNHCR in Peshawar, the Yeshis have been requested to take responsibility for a Marketing Centre for Afghan Refugee Products. Various voluntary agencies working in the camps have joined in this programme and it is hoped that co-operation in this way after the initial stage of research has been completed will benefit all and help the refugees with the marketing of their handicrafts.

Eventually it is expected that the following skills will be included in the programme: shoe-making, carpentry, silver-smithing and doll makeup.

THE OCKENDEN VENTURE Guildford Road Woking

Surrey, GO22 700

United Kingdom 
NEW RESTAURANT IN THE TWIN CITIES:

The Khyber Pass Cafe

1355 St. Clair Avenue

St. Paul, MN 55105

612-698-5403

Excerpts from a review in THE HIGHLAND VILLAGER of $8 / 13$ by Thomas

Mischke:

I he cafe (formerly Mothers Restaurant) has been in operation for seven weeks now and, according to Amini, though he's done no advertising, support from the immediate neighborhood has been steadily growing. He attributes much of that support to his painstaking efforts to insure that the food he is preparing is fresh and of the highest quality.

"When I first opened, I would order all my vegetables by phone," he said. "But most of what I got had to be thrown in the garbage. Now I drive around and find the best vegetables myself."

The variety of those vegetables and the ways in which they are prepared and served define the bulk of the Afghani menu. Entrees that normally include meat may be ordered without as well, and Amini has been surprised at the number of diners who have opted for the vegetarian version. Those who prefer meat will find beef that Amini often grinds himself as well as New Zealand lamb, considered to be the best and often most expensive lamb available.

Like many of the ethnic restaurants in this area, the Khyber Pass is family-run; Amini's wife, mother, father, brother and three sisters all lend a hand. With the exception of Amini's American wife, all are recent emigrants from Kabul, Afthanistan. According to Amini, it has been a long and arduous process geting from there to where they are today.

Amini, 32, came to the United States in 1980 as a participant in a financial analysis program with the International Monetary Fund in Washington, D.C. He had been working at the Central Bank in Afghanistan before receiving a scholarship to attend the program. After completing his six-month stint, Amini traveled to New York to visit a friend. While there, he received letters from friends in Afghanistan suggesting that, due to the political climate in Afghanistan, he remain in the U.S. He agreed and began arranging for his family to join him.

While his father was on a trip to India. Amini was able to contact him and make plans to move the family out of his Sovietoccupied homeland. In the meantime, Amini moved to the Twin Cities to set up a home for his family. He said he chose this area after taking a train trip around the country. "The people here were really nice, and always smiling," he said. "In New York they hardly looked at each other."
After a difficult and often dangerous journey, Amini's family succeeded in crossing the mountains into Pakistan and not long after made the trip to the States. When they arrived, Amini was working for Norwest Bank. He found, however, that in order to help his family adjust to their new life he would need to spend more time with them. He came up with the idea of a family-run restaurant and left Norwest.

According to Amini, it was not a difficult transition. Amini's father, Mohammed, once owned a restaurant in Kabul, and the various dishes prepared at the cafe are no different than the meals the family has been-

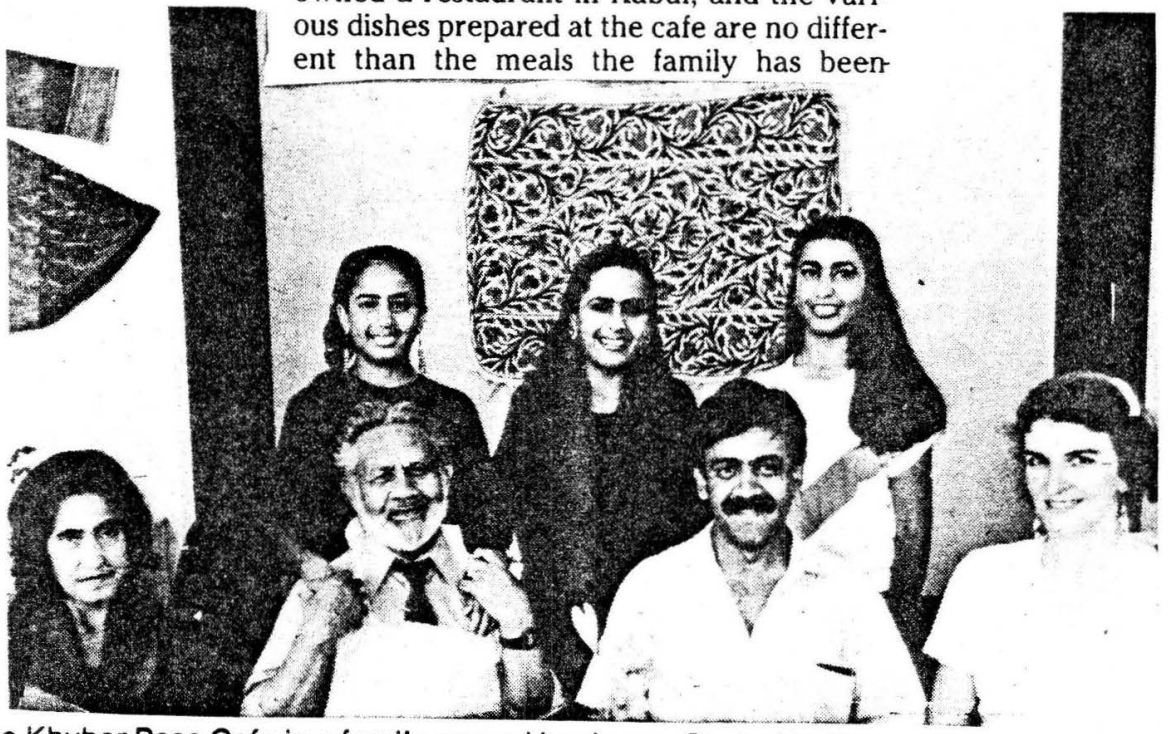

The Khyber Pass Cafe is a family-owned business. Seated in the newly opened restaur. ant are (from left), Alamtab and Mohamed Amin Amini and their son Habib and daughter. in-law Susan Bosher. Standing are Habib's sisters, Wahida, Masooda and Sabiha.

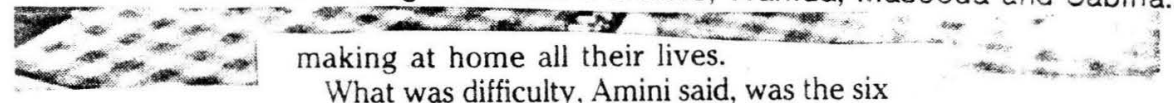

What was difficulty, Amini said, was the six weeks of cleaning, painting and repair work that was necessary in order to make the cafe suitable for serving the public. According to him, though the building itself was in good repair, the interior left much to be desired. One of the more difficult tasks, he said, was trying to remove wallpaper that had been used to cover the old restaurant's windows.

Amini said patrons of the former restaurant will notice drastic changes. The atmosphere now is clean, bright and lively, with colorful Afghani art adorning the walls, and authentic Afghani music playing in the background.

In deciding upon a name for the restaurant, Amini sent a list of possibilities to friends and asked that they vote for one. The Khyber Pass, a well-known mountain pass between Afghanistan and Pakistan, was the clear favorite...

The restaurant currently seats 46 , but if the demand grows beyond that, Amini is ready to expand next door into what was formerly the take-out side of Mothers.

Until then he is content just looking after his transplated family, and enjoying the opportunity to be his own boss. 


\section{LETTERS}

To the Editor:

I was stunned by Laili Helms' nearly vicious review of my nove1, Kabul, and in view of its many inaccuracies I feel I should be granted an equal chance to respond. [FORUM XIV, \#4, p. 30]

It is perhaps symptomatic of Ms. Helms' careless reading of Kabul that she misspelled or stated in error most of my characters' names. The father of my fictional Anwari family is called Omar, not Mohammed, the younger son is Toryalai, the daughter is Saira.

Specifically, Ms. Helms states:

1) "Roshana would not have gotten into as much trouble with her protests as Hirsh suggests." In truth, the women's demonstration I describe, in which women were shot at and burned with acid by fundamentalists, actually happened in 1970 . This is fact, not fiction. Further, Roshana wears a chadri not because it was required (and heaven knows I wrote nothing about basketball games) but because she is a person of some visibility who wished to conceal her identity while en route to secret meetings. She does not wear it at any other time.

2) "He (Daoud) is made to seem a highly social animal of convivial conversation" when really "he was known to sulk in corners at parties." Well, yes. In fact in the account of Mangal's wedding to which Ms. Helms refers, Daoud emerges from a dark corner to draw Mangal back into the shadows with him to convince him to participate in a coup. A party animal? Hardly. But clever with words, yes. 3) The number of women doctors in Afghanistan may have been "impressive" by some relative standard which Helms does not specify, but it was certainly not adequate to the needs of the people.

4) Ms. Helms claims I "admit" my novel is based on accounts by Afghan friends and not personal experience. I never said any such thing. It has been extremely frustrating for me not to be able to tell the story behind my story because my credentials are well in order. Perhaps soon I will not have to be so constrained. 5) Most distressing is Helms' repeated statement that my characters do not develop. Untrue. At the start of Kabul, Tor may be a spoiled brat, but by the end he is committed and courageous. Saira moves from confusion to clarity and Mangal from being a cautious bureaucrat to a charismatic leader of the rebellion. Even Omar realizes, by the end of the story, that his single-minded devotion to national goals has left him blind to the needs of his family.

These are fully-fleshed people, not plaster saints. To quote Time magazine. "Each has a capacity for nobility, and for disillusion and betrayal." Heroes come from mortal clay. That is why they matter.

Thank goodness Ms. Helms allowed that the "historical background is basically accurate." In larger terms, she showed no understanding of what my book is about: the internal pressures that moved Afghanistan from a constitutional monarchy in 1973 to the Soviet invasion of 1979; the personal pressures on Western-educated, politically active families who feel caught between two cultures if not millenia; and the intersection of the home and the world.* These phenomena have resonance in other developing nations, yet they are little understood by most Americans. That is partly why I spent 6 years in pain and poverty to write Kabul.

Since Ms. Helms was allowed a derisive tone throughout her review, in all fairness your readers should know that Theodore Eliot, Jr., who was the US Ambassador to Afghanistan from 1973-78, has said: "With great sensitivity, it (Kabul) explores the conflicts of a traditional society in the modern world, and that country's subjugation by a ruthless super-power. A first-rate novel." Time called it "A moral thriller," the Washington Post "The genuine article" and Kirkus Reviews

* Our reviewer is a member of such a family. Ed? 
gave it a star as "An expeditiously compressed and simplified - and quite splendidly mounted - action and angst version of the tragic and tumultuous recent history of Afghanistan, as lived through, and influenced by, a ...clutch of giant family members - intelligent, aching and doomed." Kabul will also soon be published in London and Vienna.

I hope readers interested in political themes will not be dissuaded by Ms. Helms' review from forming their own opinion of Kabul.

Sincerely,

M.E. Hirsh

Boston, MA

The 2/17/86 issue of The Washington Post carried the following review of Kabul:

KABUL

By M.E. Hirsh

Atheneum. 445 pp. $\$ 19.95$

By Marjorie Williams

Cast your mind back to a time before "The Thorn Birds," before the label "saga" was slapped on every book that dared an exotic locale, or touched down on more than one continent, or addressed the concerns of more than two or three blood relations. For it is "Kabul's" chief virtue that it is the genuine article-the fully imagined, closely researched, energetically written story fixed in a. distinctive place and time.

The block of amber offered for our inspection is Afghanistan in the period from 1973 to 1979 , under the three regimes (one a monarchy, one nominally republican and one Marxist) that preceded the Soviet "Christmas Invasion." Suspended there is the half-Afghan, half-American family of Omar Anwari, minister in the king's cabinet, pillar of Kabul society, product of "the blood of fifty generations of Pashtun mountain tribesmen."

Because Omar was educated in America and married a Bostonian, the three Anwari children are also sent to school abroad: the eldest, Mangal, to the Sorbonne in the ' 60 s; the daughter, Saira, to Radcliffe; and the luckless youngest son, Tor, to Moscow. Each member of this generation is thus situated to express some aspect of Afghanistan's plight as a punching bag, or of the tension between its semifeudal, Islamic character and the forces that would modernize it.

Alerting us early that it is going to give good political weight, "Kabul" is slow to start. Helpfully, these Anwaris are a contentious bunch. Just as Omar is tendering an honorable resignation from the king's cabinet over corruption in the royal household, Mangal is enlisting in the bloodless coup that will take power the next day. Saira, choosing exile in New York over the Islamic conservatism that would constrict the life of an unmarried woman in Kabul, carries on a love-hate relationship with her family and the country of her birth. Her love relationship is with a Russian colleague at the United Nations-an occasion for her to learn, as her feminism might have told her, that the personal is political.

Tor alone is apolitical. He might be expected to join the progeny of other former potentates among the Eurotrash, were he not such an angry young man that at the outset he's sentenced by his parents to a Moscow education. There, in the novel's very best scenes, he is redeemed by his love affair with another student, a British girl involved with Soviet dissidents.

In the course of "Kabul," the Anwaris transact all the venerable business of their fictional kind-breeding, falling in love, undergoing political epiphany, fleeing, dying and (once) even trying a hand at resurrection. That they do it in unpredictable, sometimes enthralling ways is a testament to first novelist Hirsh's talent: It's rare to find such a large cast that numbers not a single lazily drawn character or-perhaps the largest pitfall, given the book's ambitions-political sandwich board among its members.

But eventually, with the exception of Tor, his lover and his mother, the relative realism of the Anwaris makes them relatively tiresome. Too much of the plot hinges on family rancor. There is not only the rancor that explodes in one early scene, setting off a chain of circumstance that will dominate the Anwaris' lives, but also a quietly continuous, talky rancor that causes the characters again to make the decisions that will do them least credit, and their family and country most harm.

By the time the Soviets are massing at the border, they seem almost to be a particularly virulent expression of sibling rivalry.

A little more than half of "Kabul" is set in Afghanistan, and the novel's other great flaw is that these scenes are the least successful. They clearly contain as much love as research, but they're not nearly as absorbing as the accounts of Tor in Moscow or of his sister in New York. Here again, politics is one of the culprits. Conscious of our feeble apprehension of Afghan affairs, the author has written a brief "note" at the beginning of the book summarizing the history she is about to dramatize, but the concession stops there: Throughout the book, rigorous lessons in factionalism are explicated in dialogue - a form that tells us more than we want to know, because it dramatizes less than we'd like to see.

Still, "Kabul" is well worth the trip. It's inconsistently dramatic, but it's never hard to pick up, and often hard to put down. To speak in the terms of its own milieu, may it live long. 


\section{REEENT PUBLIEATIONS}

"The War in Afghanistan" by Craig Karp in FOREIGN AFFAIRS, Summer 1986. The article is based on the State Dept. 1985 year-end report.

NOSHE DJAN: AFGHAN FOOD \& COOKERY by Helen Saberi will be distributed in the US by The University Press of Virginia, Box 3608 University Station, Charlottesville, VA 22903. Cloth $\$ 15.95$; paper $\$ 10.95$. (See p. 25 )

CHARLES MASSON OF AFGHANISTAN: explorer, archaeologist, numismatist and intelligence agent by Sir_Gordon " Whitteridge, Aris \& Phillips, London, 1986.

CRIME DE SILENCE ET CRIME DE TAPAGE, Panorama des lectures sur 1'Afghanistan contemporaine by Giorgio Vercellin, Supplemento \# 44 agli ANNALI, vo1. 45 (1985), fasc. 3, Naples, Istituto Universitario Orientale.

ABSTRACTA IRANICA, the bibliographical journal for Iranian studies, published as a yearly supplement to STUDIA IRANICA by the French Research Inst. in Iran, carries items on Afghanistan. Information on the publication can be obtained from the Association for the Advancement of Iranian Studies, Univ. of Paris III, 13, rue de Santeuil, 75005 Paris.

FIGHTERS FOR THE FAITH? NO, HIRED KILLERS! by Mikhail Koloskow, Novosti Press Agency Publishing House, Moscow, 1986. Illus., $100 \mathrm{pp}$.

FREEDOM published by the Afghan Freedom Society, 1541 S. Shenandoah St., 非, Los Angeles, CA 90035 (213-858-8519). Annual subscription $\$ 18$; abroad $\$ 25$. The frequency of the 24-page tabloid is determined by contributions. It is in English \& Farsi. (See n. 16)

The Institut Suisse de Recherche sur les Pays de 1'Est (ISE), Jubilaumsstr. 41, CH-3000 Berne 6, Switzerland, issues 2 periodicals that of ten have articles about Afghanistan. ZEITBILD (in German) is sFr. 60 (airmail); ETUDES POLITIQUES (in French) is sFr. 31 (airmail).
The September SOLDIER OF FORTUNE has two articles on Afghanistan: "Captured in Afghanistan" [a weapon, not a person] by David Isby \& "Afghan Attack" by Jake Border.

ARPEL Graphics, 32 E. Micheltorena, Santa Barbara, CA 93101 (805 - 965-1551), is selling a series of oversized postcards with photographs by Roland \& Sabrina Michaud. They also have a. 12 " $x$ 16" print \& will soon have two posters. The postcards are 85 c each; the print, $\$ 4.00$. Groups interested in selling the cards for fundraising purposes can obtain the cards wholesale for $\$ 5.10 /$ dozen; the print for $\$ 2.00$. ARPEL ships COD/UPS. Call or write Chris Lyons for further information.

THE FOUR R'S OF AFGHANISTAN (REFUGEES, RESISTANCE, REGIME, RUSSIA) by Ijaz J. Gilani, Pakistan Institute of Public Opinion. $39 \mathrm{pp}$.

"The World Council of Churches \& the Afghan Crisis 1980-1984" by Vermaat J. A. Emerson in CONFLICT QUARTERLY, Vol. $V$, \#3, Summer 1985.

"The Political Economy of Soviet-Afghanistan Relations in the Brezhnev Era: A Framework for Analysis" by Syed Riffat Hussain in STRATEGIC STUDIES, Vol. VIII, \#3, spring 1985.

Radio Liberty RESEARCH BULLETINS on Afghanistan:

"The War in Afghanistan in Samizdat" by Ju1ia Wishnevsky. RL236/85. 7/27/85; "Afghanistan - No Longer 'Foreign Soil'" by Bohdan Nahaylo. RL306/85. 8/11/85; "Afghanistan: Portents of the Apocalypse?" by Aaron Trehub. RL307/85. 8/11/85 \& "No Such Thing as a Stranger's Misfortune" by the same author. RL309/85. 9/17/85.

LA GUERRE d'AFGHANISTAN. INTERVENTION SOVIETIQUE ET RESISTANCE by Andre Brigot \& O1ivier Roy, Paris, 1985. 144 pp.

Continued on p.27 


\section{BODK REUIEUS}

NOSHE DJAN: AFGHAN FOOD \& COOKERY by Helen Saberi, Brospect Books, 45 Lamont Rd., London (distributed in the US by the University of Virginia Press, Charlottesville, VA 22903), 1986. 160 pp. Paper. \$10.95.

A woman from Afghanistan once said to me, "Now that we have eaten a meal together, we really are friends." Since we had known each other for quite a while, I had thought we already were friends. The incident graphically illustrates the kinds of problems that so often arise between people of different cultural backgrounds. Consider for a moment the personal consequences if I had never shared food with this woman. I would have gone on thinking we were friends; she would have wondered why I did not seem to want to be her friend; and, in the end, neither one of us would have understood the other at all and both of us would have been the poorer for it. In a larger context, such simple misunderstandings commonly have had a negative impact on relations between whole groups of people.

Some think that one can learn more about a people through their foodways than through studies of history, politics, etc. I am one of these people. Thus, amidst the plethora of analyses of the Afghan political situation \& tales of intrigue (including several impossibly awful novels), I found Helen Saberi's Noshe Djan: Afghan Food \& Cookery refreshing, fun and very useful. The best qualities of the book are the great variety of recipes and the wonderful drawings provided by Abdullah Breshna. Look closely at the drawings, especially at the faces. They are charming caricatures, worthy of being printed and sold separately.

At least one other Afghan cook book has been available for some years - Afghan Cookery by Doris McKellar (Kabul 1967) \& the 1980 reprint of most of it, The Best of Afghan Cookery, compiled \& edited by Sigrid Weidenweber (Portland). [Kabul Cookery, Delicious Dishes from Afghanistan, containing recipes taken from Kabul Gorgers (Kabul 1978), was published by the Washington, D.C. Afghanistan Relief Committee in 1980. Ed.] Saberi's book, however, is the first to include both a wide variety of recipes as well as a less-westernized version of preparation methods. In this age of "gourmet" food and longer is necessary to make some of the the earlier book. In terms of variety, Saberi includes, for (pilau and chalau) recipes that go well beyond the usual qabili and narinj pilau. Moreover, her instructions for making perfect "Afghan" rice are the first I have encountered that produced that much sought-after result. To achieve perfect, separate grains of rice, use her "sof" method. It works!

There are too many recipes in the book to allow an evaluation of each. Having enjoyed maush pilau (rice cooked with meat, mung beans and dried apricots) at the home of Afghan friends in Peshawar and happening to have some Hunza apricots, I was delighted to find this recipe in Saberi's book. The results were authentic and excellent. 
Saberi does not discuss in any detail the changes in food preparation developed by those Afghans who have found it necessary recently to leave their country. Many of these changes make preparation much easier and produce quite authentic results (although some are a bit odd - like adding frozen mixed vegetables to mantou and aushak sauces). Vis-a-vis the recipes in this book, I make the following recommendations. First, when the author says to grind cooked vegetables (e.g., onions), use a blender with some of the juices from the meat or vegetables. Second, substitutions for tomatoes (and there are some recommended in the book) can produce unsatisfactory results. Use either fresh (peeled/chopped) tomatoes, canned whole tomatoes or the paste/puree imported in tubes from Italy. Other tinned tomato products (juices, sauces) are either too thin or too sweet. Third, many of the Afghans living in the US have discovered that oriental won ton and egg roll wrappers are good substitutes for the "pasta" required in many recipes, e.g., aushak, mantou, boulanee, samboosa. Fourth, Saberi suggests using European leeks in place of "gondana"(the Chinese chive). Since the green part is important in many dishes (boulanee, for example,) scallions are a better replacement because the green part of the leek is much too tough. Finally, be careful using the kind of ground lamb sold in most supermarkets in the US. It has a much higher fat content than ground lamb in South Asia and can produce a very messy filling, for example, in samboosas. Lean ground beef works better.

The only really weak point of Noshe Djan is its introduction. While it is not mandatory for a cook book to present foodways in detail, it would have made this book more attractive to those not familiar with Afghanistan. Saberi does discuss some of the cultural aspects of food in Afghanistan but she does so very briefly and largely ignores such topics as "hot and cold" foods, how the cuisine of Afghanistan fits into the larger Mediterranean food complex, and regional differences in Afghan cuisine. Nonetheless, Noshe Djan is an excellent addition to the knowledge of Afghan food and foodways. Moreover, the recipes are presented in such a way that they may serve both as an introduction to Afghan cooking as well as a means to expand the repertoires of those who already "cook Afghan."

Proceeds from the sale of the book are being contributed to charitable organizations sending humanitarian aid to Afghanistan.

Kerry M. Connor

University of Vermont

WAR IN AFGHANISTAN 1879-80, THE PERSONAL DIARY OF MAJOR - GENERAL SIR CHARLES METCALFE MACGREGOR, edited by William Trousdale, Wayne State University Press, Detroit, 1985. 258 pp., illus.

Many men have aspired to rule in Afghanistan but of them all the most unlikely was Major-General Sir Charles Metcalfe MacGregor. During the Second AngloAfghan War he ached not only with personal ambition but with a sympathy rare among his colleagues for the Afghans whom he was fighting.

No doubt his upper lip was stiff enough to hide from his comrades-at-arms the turmoil beneath the braided jacket. But he displayed his feelings to his diary. Shortly after his death this diary was published in a version sufficiently expurgated to avoid giving offense to anyone vaguely powerful and to surpress the human emotions so naively spilled there. Now William Trousdale, a curator in the anthropology dept. of the National Museum of Natural History, Smithsonian Institution, has brought the complete diary to life and shown that the war 
described therein was fought by hunan beings. His helpfil annotations tell us who they were.

"The only solution is to take the country, and make me Amir. I would do it, but only on condition of a peerage, not under," MacGregor wrote in his diary in 1880. Twenty-one years earlier he had written, "I should like to go to those rude people and make a kingdom of my own."

History tells us that this Englishman never became ruler of Afghanistan. But he had a second and more likely ambition, to be decorated with the Victoria cross. He never achieved that, either, and never had the opportunity to deliver the acceptance speech that he wrote out in his diary.

Afghans who still think harshly of Roberts, the general who became Lord Roberts of Kandahar, will be happy to know that one of his compatriots also thought Roberts unduly vengeful and criticized "Bobs" often, not only for military tactics but for too many hangings.

History becomes more and more a matter not only of who shot whom but how they felt about it. Trousdale's book is a meaningful contribution to the annals of an important time in world history.

Rhea Talley Stewart

Manchester, Connecticut

\section{RECENT PUBLICATIONS con't. fr. p. 24}

LES BAZARS DE KABOUL by Andre Velter \& Emmanuel Delloye, Paris, Ed. A.-M. Metaille, 1986. 237 pp. A reissue, minus the photographs, of a book published in 1979 by Editions Hier \& Demain, Paris.

"Die Sowjetunion in Afghanistan. Von der Zusammenarbeit zur Besetzung: 1947 bis 1986" in MILITARPOLITIK. DOKUMENTATION (Frankfurt) 9, 1986. DM 12.50.

"Afghan Ambush. Yank Medic Lives to Tell the Tale" by John Moughan in the June issue of SOLDIER OF FORTUNE.

BRITISH PLOTS AGAINST AFGHANISTAN Pages from History by Naftula Khalfin, Moscow, Novosti Press Agency, 1981. $100 \mathrm{pp}$. Prof. Khalfin is also the author of "Vengeance Waits in Jagdalak" \& "Victory Trumpets of Maiwand" which are also about the "Afghan people's heroic struggle against British aggression." [The Novosti Press Agency Publishing House is at 7 Bolshaya Pochtovaya St. 107082 Moscow, USSR.]

\section{CALENDAR}

A 1987 calendar, with photographs in color \& black \& white by Herbert Maeder, is available from Aktion Afghanistan, H. Bracher, Jurastrasse 71, 3013 Berne Switzerland. The price of the $46 \times 30$ calendar is SFr. 19 plus postage \& handling. There is a discount for quantity. The same organization also has 6 color post cards for SFr. 7 plus postage \& handling.

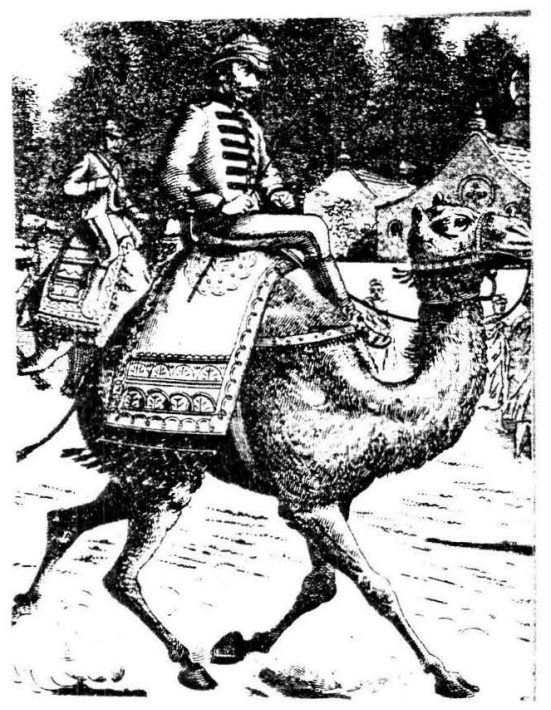




\section{AFGHANISTAN}

The Soviet War

By Edward Girardet

St. Martin's. 259 pp. $\$ 19.95$

\section{By James Rupert}

HE SCHOLARS and policy-makers of the time called it "the great game": the 138-year struggle between the British and Russian empires to dominate a harsh central Asian land of fiercely independent shepherds and farmers.

In 19th-century Afghanistan, it was the British who seemed to have the upper hand. From the frontier of British India, they periodically invaded the Hindu Kush to ensure that successive Afghan kings performed dutifully their role as buffers, keeping the Russians at a safe distance from the crown's most precious colony.

"Fighting him was good shikar," a Pushtun tribal elder says of the British invader. $\mathrm{He}$ speaks in the opening pages of Edward Girardet's book, perhaps glossing the past with nostalgia: "We respected each other. We could look one another in the eye. We had certain rules."

But, in the Afghan guerrilla war against a 20th-century invader, the Soviet Unior: Girardet writes that there are no rules. "The 'Great Game;' if it ever truly displayed a sense of fair play, has become a gruesome, pitiless contest of strength, endurance and basic survival, for the greater part ignored and forgotten by the rest of the world."

Of all the wars and crises along the front lines of the current superpower "great game," the mujaheddin's resistance to the Soviets is the least accessible, least reported and least understood. For those wondering just what is going on there (and who suspect that it's' more complicated than the CIA agent's romp through the Panjshair Valley in Ken Follett's 1985 thriller, Lie Down With Lions, there have been few readable books to learn from. Girardet's is the most comprehensive, and perhaps the best, English-language book so far to explain the Afghan war to general readers.

Girardet first reported from Afghanistan three months before the Soviet invasion in 1979, and has been back six times since then for the Christian Science Monitor. Among his firsthand observations of this bloody stalemate are vivid accounts of its brutality. From a 1981 trek through Nuristan, a mountainous eastern province, Girardet writes:

Long thin waterfalls plunged down narrow gorges, their rising vapors nurturing minioases of ferns, mosses and trees, while dozens of streamlets laced their way across verdant slopes...

"Mines had not occurred to anyone. The

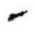

caravan was hardly two hours inside Afghanistan when some of the mujaheddin up front stopped to make tea. Waiting for the rest to catch up, a young Panjshiri, Shah Mansour, crossed a small stream to hunt for firewood among the bracken and wild rhubarb on the other side. Suddenly, a sharp explosion and his right foot was severed below the ankle, a bloody mess of flesh and bone. A few feet away lay the pathetic remains of his black plastic shoe and the metallic fragments of a booby-trapped watch."

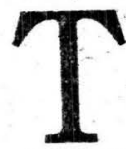
HE BOOK'S centrai feature, though, is Girardet's hal- ad reporting and analysis of the pervit dering complexities of this war anc the tradition-bound Islamic society in its grip. Largely because of these questions, Girardet's book is not an invitation to a casual reader to stay up all night. You have to be interested in the topic.

Americans should get interested. With the Reagan administration reportedly including high-tech Stinger anti-aircraft missiles in U.S. arms shipments to the guerrillas, Girardet tells how the mujaheddin, mostly unschooled, misuse even much simpler weapons.

Girardet describes how barriers of tribe and tradition among Afghans, built on centuries of conflict and mutual distrust among the many ethnic groups, have helped keep the resistance fractured. $\mathrm{He}$ also identifies the trends and personalities, such as young commanders inside the country, that tend to work toward the unity that will be essential to strengthening-even perhaps maintaining-the resistance.

These complexities and rigidities of traditional Afghanistan must be understood by anyone, including the U.S. government and the increasingly active private organizations in America, who think to aid the Afghans.

Girardet is a reporter who seems to relish whacking through the bush of obscure lands and writing home about it. Last year he sat on a pile of Afghan rugs in his Paris apartment, grimacing at a small computer screen as he edited his book. "I've had enough of Afghanistan for now," he said, and launched into a description of a planned trek along the length of Africa.

Girardet's own multi-cultural background, which included schooling in five countries, gives him some of the essential flexibility to report from strange and distant datelines. It also affects his speech, which is vaguely British-accented and can drift almost unconsciously from English to French and back again. It may be this same background that produces an odd turn of language in the book, which is sprinkled with mixed metaphors and juggled jargon. Intending to explain how the dominant Afghan ethnic group represses a minority of Mongolian origin, Girardet writes "Pushtuns... have traditionally treated the Hazaras as underdogs."

Also, the book's dedication, "to those for whom freedom is worth fighting" seems not exactly what was intended.

Girardet's Afghanistan has not been well-served by its editors, who let numerous spelling and typographical errors into print, and who might have added a glossary.

The book also suffers from some of the usual problems in dealing with Afghanistan-such as the dearth of good maps. In my own trip into Afghanistan last year, for The Washington Post, the mujaheddin repeatedly asked me if I had any good maps of their country.

Another inevitable problem: statistics on Afghantista and the war are rare and quickly go out of date.

Now that the Soviets are imposing themselves in Afghanistan as the British Empire once fearedand as James Michener warned they might in his novel, Caravans-a book such as Girardet's is essential. Recent American books on Afghanistan have been mostly scholarly-leaving Europeans, particularly the French, to publish general accounts of the war for what seems a more interested public there than in North America.

Happily, Girardet's balanced and informed assessment of this war seems only a beginning for English- language readers. Collins publishers in England is planning a January release of a book by one of the most respected American researchers on current-day Afghanistan, Michael Barry. The book, first published in France laste year, "will"be" titlèd The Kingdom of Insolence.

James Rupert is a special correspondent for The Washington Past in South Asia.

\section{BOOK WORLD/JUNE 15,1986}

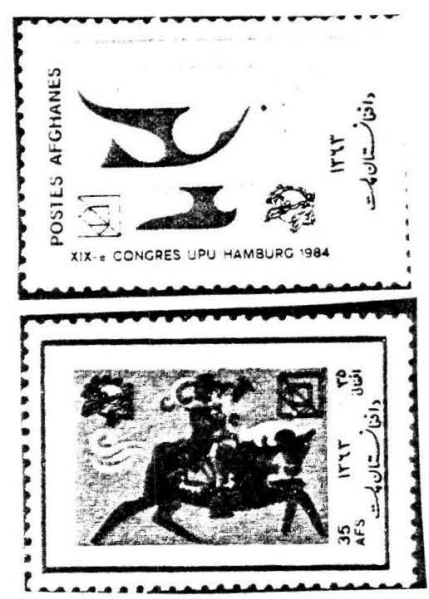


A CULTURAL NOTE FROM BAKHTAR 6/19

Mihli Atan (national dance) is a very famous tradition in Afghanistan, particularly in Khost Grand District. All people - men, women, boys \& girls know how to perform it. This dance is performed with great zeal \& enthusiasm even in the remotest areas of the Khost Grand District, particularly on wedding days, festive days, on the eve of the new year \& on the birth of a boy in the family.

To perform this tradition, generally on wedding days, people who were mostly holding guns come together \& make a circle around the 3 or more drumers standing in the middle. With the beating of the kettledrum, the people-start dancing. The number of dancers is from 5 to 50 or more. While performing this ancient tradition, the dancers sing, individually or in a group, special songs. The armed men start firing in the sky. They have tightened their belts holding bullets.

Long-haired persons are most welcome $\&$ are wholeheartedly accepted in the dance. A humorous \& mirthful person walks around the circle encouraging others to perform the dance satiately (sic) \& joyfully.

Women perform the dance at a special place, where men as well as boys over 10 are not allowed. The women wear special clothes kept for this day \& color their hands \& feet with henna. They come together \& make a circle which is supervised by an old woman having a stick in hand just for making fun \& instructing girls to perform it nicely. By seeing this dance all people become happy.

Another kind of women's dance on wedding \& engagement days is called gawun. Here a group of women sit down \& start singing special gawun songs during which 2 girls start dancing while others watch \& encourage them by clapping.

Another ancient tradition which must be observed on wedding days is called shori (clapping verses). It is generally done during the night after dinner. Here the people are seated \& one person is standing \& starts singing, while others are clapping \& repeating the first verse loudly \& joyfully. Mostly 2 persons compete with each other in singing. They tell an interesting story in a poetical way. Sometimes the shori takes a whole night which is done by illiterate persons.

The Khost Grand District, located in the southeastern part of Paktia Province near the Pakistan border, has a population of over 150,000. It has 3 districts \& 3 sub-districts having over 100 villages. Over $70 \%$ of the people are engaged in agricultural activities \& others are traders, etc. The Khost Grand District has lovely natural scenes. It has high mountains. The district is very famous from a strategic point of view. That's why the Afghan counterrevolution, at the behest of their masters headed by the USA, turned it into a terroristic center against Afghan people which were completely destroyed recently by the armed forces of the DRA during which 2,000 bandits were killed $\&$ more than 4,000 were seriously injured.

The book of "Osta" (Buddhist religious book) called the district "Sawast" in Sanscrit language. It was famous as a most suitable place for living because of its lovely weather. Hence it was called Khost... The district has an area of 420 square kilometers. 
Pious Muslim people of Afghanistan celebrate the biggest Eid Adha (sacrificing festivities) by slaughtering sheeps, cows \& camels. This type of slaughtering sheeps, etc., are not the rites of today or yesterday, but those of a million years ago, that is, right from the time of Moh'd Ebrahim, the then prophet of Allah, God of the universe, mankind \& all the creatures... Ebrahim one of those nights had a dream that Allah ordered him to slaughter his son, Moh'd Esmail... In a bid to give a positive response to the order of the God, tomorrow...Ebrahim put new clothes on Esmail \& colored his eyes telling his wife about the matter \& took his son Esmail to a place called "Menna" to be slaughtered. The moment Ebrahim wanted to put the knife at the throat of Esmail, all of a sudden an angel came $\&$ replaced a sheep instead of Esmail.

This type of performance prevailed for almost tens of centuries til the time of Moh'd the first \& last Prophet of Islam. Abdul Mutaleb, grandfather of the Prophet of Islam, also had a dream that Allah the God of the universe ordered him to slaughter his son Abdullah, father of Moh'd. Abdul Mutaleb; took Abdullah to the base of "Kabba" in Mecca to be slaughtered but the moment he wanted to slaughter him, fortunately, Abdullah was also released, like Esmail, and a cemel (sic) was placed instead of him by the angel of God.

In performing Eid Adha, those who go for Haj pilgrimage, hundreds of thousands of sheep are brought by them, sheaving (sic) their heads except women, \& by wearing white clothes go around the house of God \& becoming haji.

The people of Afghanistan consider the Eid Qurban as a gala festival \& marking day of sacrifice, peace, solidarity, conciliation, a day of brotherhood $\&$ a day void of hostility, subversive \& bloodshed... The Eid Qurban, which commences with Eid prayers in the congregational mosques, besides slaughtering sheeps, cows, camels, etc., brings hugging \& kissing seen between the people who have not a good relation with each other. Sheeps which are to be slaughtered by only one person it also divides in 3 parts similar to the cows \& comels (sic) \& distribution proceeds in the same way, provided the sheeps, cows or camels got to be male one.

Regarding Afghan traditions, the youngsters visit the elders on the 1st day of Eid Qurban. First of all the people go to their parents in case they are not living together \& to the father-in-law of bridegrooms. But priority is given to those who have lost a loved one before the Eid.

The tradition pertaining to Eid Adha in Afghanistan shows the fact that, during the engagements the bridegrooms, after praying in the mosque, straight away goes to his fiancée family taking with him a fat sheep along with precious cloths, sweets, confectioneries, cosmetic stuff, jewelry ornaments \& musical group.

On these days the children \& even adults \& elders, depending on the economic situation, wear new clothes \& go to the rally centers of the people - places of recreation, parks \& different games areas. Though during the days of Eid rum (sic) fighting is common to be done in each \& every corner of each district \& province of the country. But apart from that the adults find delights in cock fighting, dog \& birds fighting, egg hitting, raffles, etc.
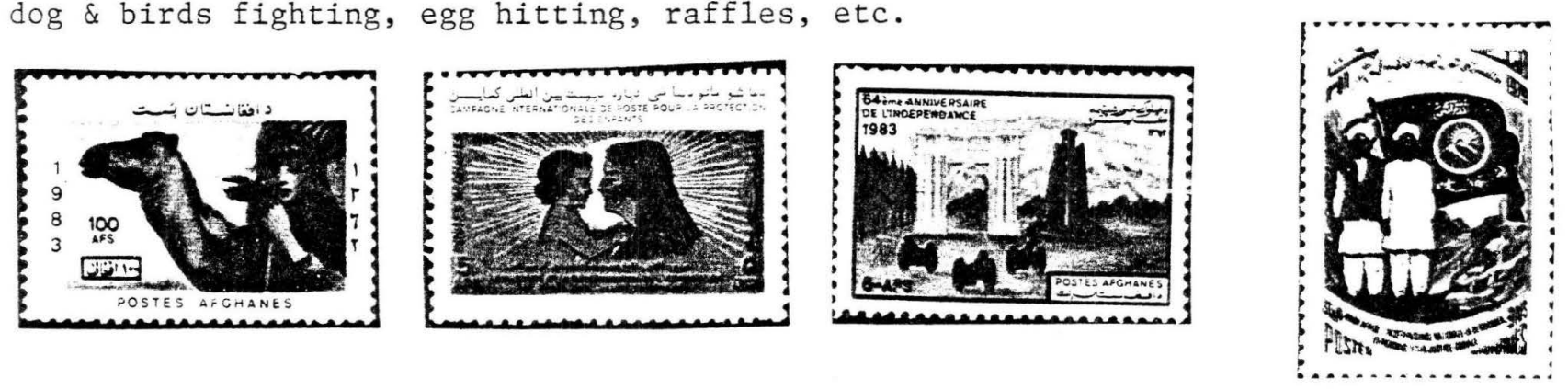


\section{NFF, key instrument of}

national unity, enceavour

\section{NAJIB ADDRESSES NFF. FIFTH FOUNDING ANNIVERSARY}

\begin{abstract}
Text of the speech of Comrade Najlb, Genera Secretary of the PDPA CC delivered at the sesslon marting thie 5th anniversars of the National Fatheriand Front of the DRA:
\end{abstract}

Dear friends and bro-

Today is a greit and auspicious day. We celebrate today the 5 th anniversary of the NFF. This is the festival of ove 800 thousand real work ing and patriotic peopl of new Afghanistan.

It can be said without exaggeration that this is the nationwide festival of social activities of our people for prosperity of our dear homeland

The Politburo nernbers have today come.t ere to congratulate th: Af ghan people, all $\forall$ ose who joined the NF no vement, all the activ sts and employees of the $\mathrm{Fr}$ ont and esteemed $\mathrm{H}$ : tif president of the NFE, he prominent patriot $c$ : h country on the occisi $n$ of this glorious fes iv: 1

W'e mark today's anniversary at a radical tur of revolutionary growth. The acceleration of activation of all our work $\varepsilon \mathrm{nd}$ struggle constitutes i ie essence of this historic a urs $E$ and stage of aition, the prelude of which was set by the 18th plenum of the PDPA CC

The fundamental nor$\mathrm{ms}$ of 16 th and 17 th plenum determined the long. term prospective strateg.. The task is its exçcuall walks of social life now carried forward in the party and country is directed only to this end. The resolutions of the 18th plenum of the FDPA $C C$ and its line aimed at renovation of the style of work and stepping up of the pace of revolutionary changes won the support of all people, party and ocial organisation.

We are duty-bound to increase our efforts three fold for ever sooner cessation of bloodshed, restoration of peace and tranquillity in our ancient land and act purposefu!ly. persistently and uninterruptedly; act. act ard again act.

The glorious April Revolution is a national democratic. anti-imperialist revolution of all our peo plc. its objectives and id eais are close and known to all

As is mentioned in the Programme of Action:

"We took over power reople and progress the the fatherland. All the measures that we carry out are directed at realisation of such noble tasks. The national democratic pation and conformity interests of majority of Afphans, all classes, soAfghans, all classes, soour people. And this re volution is the joint efforts of people for emancipation from the yoke of siavery and tyranny, for decent life of the working man.

The national democratis April Revolution is the unity of aims and demiands, unity of plans and their execution and unity of revolutionary and patriotic action and this unity is first and foremost reflected in your organisation that is the hoerlant Front.

The NFF was founded five years ago as a democratic mas organisation whose main aim is mobilisation of all patriots for ensuring. deepening and expansion of the changes begun with the victory of tie April Revolution.

In the course of these years, the' front bas traversed a patb of heroic striggle, its ranks grew mber of its primary organisations, collective and individual members inc reased and accumulated noteworthy experience of work with the masses.

Today on the anniversary day of the NFF we should speak openly and without any false modes ty and we thank you, de ar patriots. for all the work accomplisher in honour of the homeland. At the same time, we have to look courageously to timniurrow and see all the barriers obstructing the path of our progress. In $\mathrm{my}$ opinion, we all have a unified view with regard to the need of definite re novation of the front's activities.

The main fact is that the NFF should not duplicate or copy other organ isations. As you know, su ch a tendency exists. You dear comrades sho ads as well at attra and asticular abj and particular objectives and they exist.

The NFF is our biggest mass organisation. Now, all the process of democratisation of life is naturally in your bands. The NFF opens wide opportunity for the participation of masses in the adminis tration of the country. The Central Committee of the PDPA well realises what a large amount
PDPA supports ever activcly the noble initiatives of the NFF and will clcvate its role in organising all the affairs of the rural population in the employment of preachers. village chiefs, and its participation in distribut ion of gratis assistance of the Soviet Union to nu people and as a whole in solving the

of devoted work has been carried out by the memfor and conducting elecstate power and administration, as well as in stration, as well as in gahs and councils.

I would like to recall that making use of its high authority the Central Council of NFF has introduced over 40 per
cent of trustworthy newly elected representatives to the Revolutionary $\mathrm{Co}$ uncil of the DRA. The Central Committee of unts on your furner active heip ii th conduct of electicns du to be held for the State Council of the DRA. In thi near future, you, will share the assessment wo $\mathrm{rk}$ and discussion on the draft of the new constitu tion of the DRA.

This is a great and in teresting work.

We say right now that the role of the N'F wouId be determined in the constitution, pertaining to the socio-politizal lifo sition will be maile precise in expansion and strengthening of the state power.

In the future toj: our party and state $s$ ial solve through the $N$ i most complicated anc gr cat problems. You ave undertaken great rany undertaken great liany
measures for the gr.wwth of the intermational aut hority of our home and. The arrival of gutsts fr. on various"countres for participation in $t$ is anniversary celebration bright manifestation of this fact. We heartily welcome you dear brothers and internationalists from the country of Lenin. the Soviet Union, from Bulgarie, Vietnam, Poland. Etheopia. Sudan and Syria. Afghan hospitality requires that more friends always be in our homes.

It is the NFF nhich should establish wide frie ples of Islamic countries, member countries of nonaligned movement all progressive :cree; of all progressive icree: of the undelaysble asks of the NFF.

In some cases, the rights of NFF are lisc uss. ed.

I would like to $r$ ite ate decisively that the $C$ nnt-

Let us think what the National Fatheriand Fr ont is? National mesns all nationalities and ethnic groups of the country i.e., Pashiton Tajiks, Hazaras, Uzbeks, Nooristanis, Baluchis, $\mathrm{Pa}$ shais and all fraterna and equal nationaliti s The unity of multi-na io nal Afghanistan - in a ilistoric new society and single Afghan nation is one of the basic tasks of the revolution and $\mathrm{ycu}$ can, more than others, discharge your part in the solution of the national issue.

National also mesns 


\section{KABUL,}

The following decree of the Presidium of Revolutionary Council of the DRA on additional measures for strengthening the armed forces of the DRA has been issued on June 14, 1986.

The RC Presidium of the DRA, considering the fact that the undeclared war of reaction and imperialism against our country acquires wider dimensions, and with a view to strengthen and complete the armed forces ranks for the total and absolute extermination of the counter-revolution, keeping in view resolution No. $136 / 6$ of June 5, 1986 of the Politburo of the PDPA CC and following the provision of $\mathrm{Ar}$ ticle 44 of the Fundamental Principles of the DRA, endorses:

1- Only those youth can enter the higher and vocational educational in stitutions who have completed the term of military service in the ranks of the armed forces of ments of exemption from military service.

military service. mpiete their military se rvice are admitted to the higher and vocational education institutions inside and outside the country. Those who are demobilised in the spring te$\mathrm{rm}$ can join the higher and vocational educational institutions. The term of their academic absence, spent in military service, will be condoned for the purpose of attendance after their enrolment in the educa-
tional institutions.

-From the beginning of the new academic year $366 \mathrm{HS}$, in addition to ed their military service, ed their military service, persons who are less than
18 can enter higher and 18 can enter higher and
vocational educational institutions, and on completing the age of 18 they will be sent to military service. After the completion of military service, they join the same class without any examination. 2- Those who are studying in higher and vocational educational institutions inside or outside the couritry, in case they have not done their military service, are sent for two years after the suceessful completion of their studies to the ranks of the DRA arrned forces. After completing their two year servic:s. they are given the $f$ rst officer rank and $\mathrm{m}$ it: ry card.

If such peope volunteer to cont:nu? serving in the armel furies, they can remain as i rmy officers. Otherwise, they are demobbed after complet. ing two years ervice in the ranks o: the armed forces.

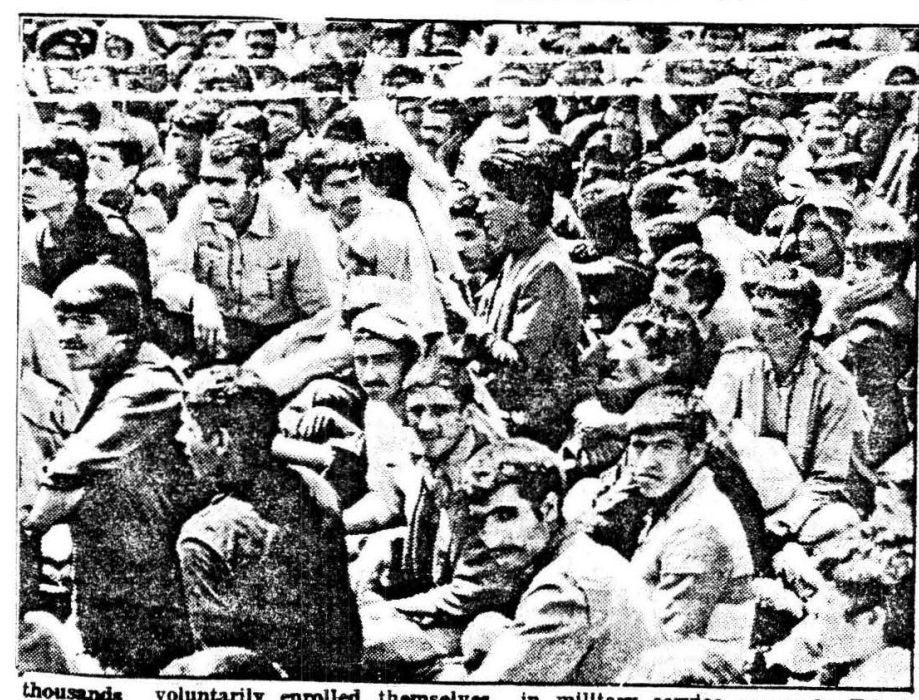
to enilst.

3- From the beginning 7- The Chief of Staff

of 1366 HS acacemic year, of the DRA armed forpersons who have either ces is assigned to prepare completed their mi- precise statistical data on litary service or those studying in educatpossess vald do- ional institutions, inside cuments exempting th- or outside the country, em from militiry serv- or outside the country ice, can join tha prepara- who are 18 or above alon-
tory faculty an'i can be gwith their profession, fisent abroad for study.

\section{4- Those stuilying}

higher and yocitional eqd. ucational institr tions abroad will be employed after completing their studies, accore ing to therr professions. Aiter six months fror the comm etion of sturlies gradL tes who have not compl eted their military service shall enter, in accord ance with a tic e two of the decree, railitary servi ice. They ar. admitted their former working places.

5- Those who are studying in schools or lycees and completed the age of 18 , either in 10 th $\mathrm{gr}$ ade or lower classes, are sent for two years to military service.

Students who are mobilised from the 10 th $\mathrm{gr}$ ade of schools to military service can receive after their two year service their 12th grade certificate on passing an exam ination. Those who could not pass the exam or those studying in lower classes are admitted to a higher class.

6- Those who have completed their military service can continue their studies, without any entrance examination, in higher and vocational educational institutions inside or outside the country.

Those who are demoh ilised from military service after the beginning of the academic year can of the academic year can
begin their studies in hibegin their studies in higher and vocational educational institutions on the basis of the first paragraph of this article. eld of proficiency and when they are to be sent to military serivce, so that they are assigned to the armed forces after co mpletion of their studies as soldiers, non-commissioned officers and officers according to their

8- The Ministries of Education and Public Health and State Committee for Labour and Social Security are dutybound together with the Cinef of Staff of the atmed sario in pacpase' w1thin two months precise data about teachers, doctors and medical staff age group 18-40 who are not working in their expert fields for serving as political activists, for eradication of illiteracy and giving medical service in the armed forces. The Chiel of Statt of the DRA armed forces is assigned to send to military service after the agreement of the Central Committee of the PDPA and Council of Ministers of the DRA and according to their expert fields, those persons covered by the said list and being eligible for recruitment.

$9-$ The measures adopted by this decree are extraordinary and applicable for the present military conditions. They will of course be annulled after the total and absolute annihilation of the counter-revolution, majntenance of peace and security in the country.

10- On the basis of this decree, the - following amendments take plation of studies" shall be

\begin{abstract}
in the law on milita the Official Garette No 12 dated January 10 1980 and its addendums.

- The term of military service for those enrolled after completion of their studies in higher and vo cational educational ins titutions is two years. Article 55 of the $1 \mathrm{av}$ on militar
\end{abstract}

The words "owing to continuation of studies" be deleted from Article 52 of the law on military service.

The words "exempted for the period of continudeleted from Article 56 of the law on military se-

11- The decree comes into force from date of its assent and shall be published in the official gazette.

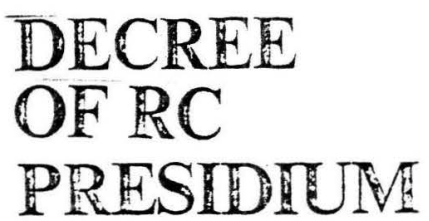

KABUL

The following decree of the RC Presidium of the Democratic Republic of Afghanistan on pardoning individuals $x$ ho avoided joining military service has been issued Kabul, May- 29, $198 \mathrm{C}$ In pursuit of its humanitarian policy. and un der clause 43 of Article 6 of the Fundamental Principles of the DRA. the Presidium of the Revolutionary Council of the DRA, taking acs ount of the fact that large number of servicemen and those under recruitment to military service who had avoided serving in the army due

to enemy propaganda in fluence are nowadays returning voluntarily to military units and com missariats for serving in the ranks of the DRA armed forces, endorses: Article 1: Those servic emen of the armed for ces who formerly des erted their units and detachments as well as those under recruitment to military service who avoided serving in the army ranks would be pardoned from punish. ment provided that they 


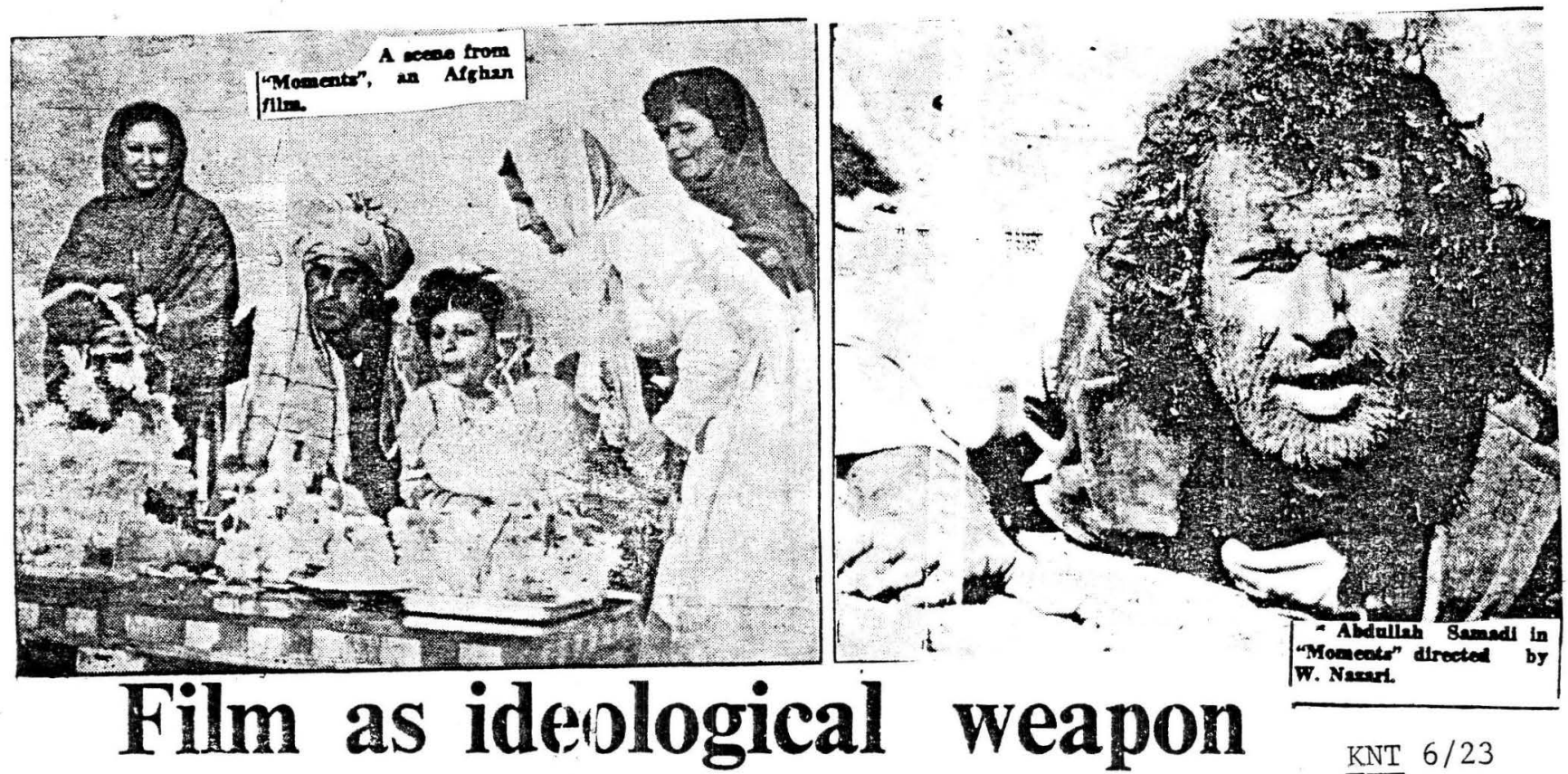

The Afghan Film Ors aniration produces four full-length feature films. tourteen documentaries and over 42 .newsreels. according to plan each year. It also dubs mor than thirteen foreign fiIms a year into the lang uages of our people.

Directors of Afghan FiIm play an important role in the production of artistic films. Most often they write the screenplay and scenarios and ace also.

During the years of April Revolution, film makers of the Afghan film bave had significant achievements to turn the medium of cinematogr- te--revolutionaries and ctionary supporters.

weapon against the tir-revolutionary bandits and all enemies of our beloved country. Afgh an film sends its film cr ews to the remotest villa ges and hamlets of Afgh anistan regularly where they pick up real picturis of the village life. So metimes they are confronted with subversive ac tions of counter-revolutio naries, but they valiantly fight them. When shnoting a film they have camera in one han

Afghan films produc ed in recent years, reves the terroristic and subv ersive acts of the coun
As a matter of fact, stu.lios of the Afghan $F . I m$ Organization have n.)t adequate technical $\mathrm{fa}$. c lities to produce a full lingth colour film. They a:e suited more for shooting shor documentaries and nu wsreels, but cinemato. aphers of the organization produce full length pictures in the same studios by their inefatigable endeavours.

Under to an agreem$\mathrm{n}$ entered into between the DRA and the USSR, t present Afghan color tilms are being processed at well-equipped stud
of the Soviet Union.

Further, Afghan Film inaintains close relations with cinemas of the friendly countries, as well as of some European and Asian nations. It has also business relations with some film companies. For example, it purchase foreign films for screening at movie-theatres of $\mathrm{Ka}$ bul and provinces.

Afghan Filin Organiz ation launches films weeks and festivals of the fraternal countries which enable the public to know more fully the developin ent of cinema in the So- ia, Bulgaria, Cuja India and so on.

Thanks to the April Revolution, which brought our cinema to the international scene. ma. ny Afghan films have obtained recogn tion abroad by taking part in regional and internitional film. festivais.

"The traveller", \& recent production of Aghan Film was awarder prize at Tashlsent international Film F'estival of Asian and Afri an countries.

Afghan direc pro have aiso served as members of the jury a in ternational film fo stivils and conteste.

\section{Badakhshan moves ahead}

Badakhshan is one of defence of the revolutthe north-eastern provi- ion like their other comnces of the country and patriots, for they know has $y 0 t$ an area of 47,403 $\mathrm{Sq} \mathrm{km}$. It is a mountainus province where are ocated branches of the Vakhan, Pamir and $\mathrm{Hi}-$ adukush mountains. The nhabitants of the province are Tajiks and Turkmans who speak in Tajiki, Turkmany, Qarghazi Wakhy Sheghnani and Aiskashimi languages.

Badakchshan was also salled Balkhshan which was an old city and the rapital of Badakhshan and the present Faizabad probably was situated in this city. Faizabad, capital of Badakhshan in the past was called. "Jorgan Deh".

Time passed and despite the pains and sufferings caused by the old despotic regimes, gave place to hopefulness. Revolution triumphed and brought changes. The working people of Badakhshan who hear those old terrible memories aro today in the forefront of committee, as a of the joint work and activity of party committees. social organisations and state organs and people's participation, in the space of between the 16th Central Committee of the PDPA, 42 villages we re freed from the trouble of counter-revol ution and 1468 persons were enrolled in the armed forces. A large number of the counter-rev olutionaries were crushed and their eight bands surrendered to the revolutionary state.

The party's organisational strength in the more primary organizations in the residential areas of the workers have base of the revolution has expanded and masshas expanded and mass- around the party. People's representatives have been elected to local organs, and also two outstanding prsons are members of the Revolutionary Council. Elections have taken place in the 372 taken place in the 372 villages and five districts and three subdistricts
and also in Faizabad city. and 17 th plenums of the province is increasing ed in which 3558 students are enroled. After the holding of election and as a resul of attemp ts and endeav ir liy these organs, $52 \mathrm{~km}$ of the roads were repaired and about 22,865 Afs distributed to the religious scholars as aid. Moscuios have been repaired a nd biult. From the beg nn ng of the implementati.in of th new orase if lind and water. forms in the province if HS 1361 up to the ent of th: $y$ ₹ar HS 1364, 9,198 lavd. wnership documents vere distributed to 3792 landless and petty landholders vering $8,553,61$ jeribes of land ( 5 jeribes equal to one hectare).

At present, 11,169 persons are attending 583 literacy courses taught by 356 teachers. $1342 \mathrm{li}$ terates graduated from these courses.

Badakhshan inhabitants are mostly peasants and cattle breeders. Eight consumer cooperatives, two handicraft and 38 agricuitural cooperatives are actively serving them.
The building of a fruitjuice canning factory in Baharak district construction of a hydro power station with a capacity of $350 \mathrm{KW}$ in Faizabad city, a health centre in Khwahan district, a Watan nursery in Faizabad city a radio relay station in Faizabad city and building and repairing of a number of sch. ools are included in the province's first five year plan after revolution which will go a long today to meet the demands of the local people.

At the same time so me difficulties are also experienced in the district which can be solved by proper ac tion. For example, th water of Kokcha river is not used properiy, enough clean drinking water is not available to the people and because of the non asphaited roads essential goods are not transported timely from Kunduz and Takhar to the province. The powe supply system is not stabilized in Faizabad city
and lack of electricity af-

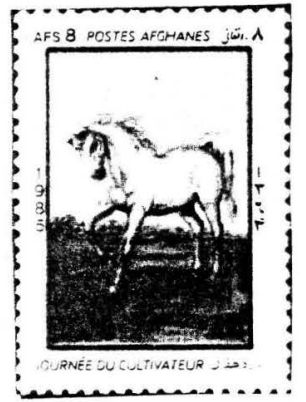

fects radio and T.V. transmissions.

The medicines needed by the department of public health have not yet been delivered to the department. The Daily Badakhshan has remained unpublished because of lack of paper. Many talented men and women do not find the opportunity to work.

Defeat of the counterrevolutions has increased the people's confidence 


\section{Preserving Herat's historical monuments PROJECT WITH}

Ferat, the widely kno wn ancient city of Afghanistan had enjoyed a DTide of place in arts, culture and science through centuries. In the mediaeval ara, the city became pro sperous and enjoyed high level of civilization, the relics of which can be found even today. As a consequence, Herat has received wide attention of historians and archaeologists throughout the world.

It was therefore natural that the United Nations' Educutional Scientific and Cultural Organization (UNESCO) founded a programme to restore and preserve ancient Herat, as a center of Islamic culture in Asia.

The issue 7as discussan :- As iference of the forion rirsters ui the Islamic "countries heId in Jeddah, 'the Istanbol conference and finally at the UNESCO conference held at Nairubi during 1975-1976. After these prolonged discussions Herat was included in the international campaign of the UNESCO

With the financial and technical assistance of the UNESCO, the directorate for Preservation of Historical relics of Eerat undertook the project of the Ekhtiaruddin fortress and minarets of the Herat city in 1976.

Taking it's preliminary steps, the International Project of Herat, began a study and survey of the Behzad Artistic School (Behzad was a great painter of Herat during the Timurid period. Many scholars have called his.. the Michelangelo of the Orient), of the glasses, tiles and stone fragments, engravings, carpets and silk costumes and all remains of the ancient times from the point of view of tourism.
After the victory of April Revolution, in addition to recording surveyi$\mathrm{ng}$ and confirming the historical monuments of the city, the Intemational Project of Herat also begun the reconstruction of all the historical relics.

Below is a discription of some of these Kist. orical monuments restored or under restoration.

1. The Elchtlaruddin fortreses:

The Flotiaiuciuin for tress is one of this most wonderful fortresses of Asia and even of the world situated in the north of the ancient city of Heral and built by Ekhtiaruddin, the commander-in-chief of the city at the time of Malik Fakhruddin, it was ruined by Timur Gurgani and reconstructed during the The fortress had sutfeed many damages thro ugh centuries and the International Project of Herat is conducting the restoration

cost of tens of million Afghanis. The project has restored many fences, towers, arches, rooms and other parts of the fortress without lo west big porch of Gasar-
gah campus under rep-

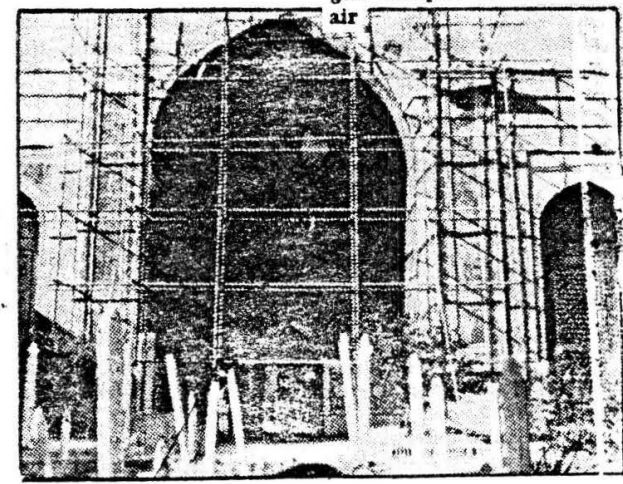

ical genuineness. The a national and ethnographic museum, libary, exhibition halls and galleries of the original handicrafts of Herat people in the fortress.

2. Monuments of Gaxargahi Sharif:

Gazargahi Sharif is located $5 \mathrm{~km}$ east of the $\mathrm{He}$ rat city and in the neighbourhood of a mountain called Zanjirgah.

The tomb of Khaja Abdullah-i-Ansiari, a great scholar and agnostic, Zamigar Khana (adorned house), Namakdan (saltcellar), Houze Zam Zam (houze mcjr; basin and Zam Zam is the name of a very famous well near Kabah). Masjidi Zirzam. ini funciargreund inusuue are amoung the hret aciouricat monuments or They are all living rem architecture built during the period of Shahruk

The International Project of Herat has repaired and restored fences, rooms, porches, courtyards, shrines and other relices of the Gazargahi Sharif to their original forms. time of Shahrukh Mir.

west big porch of Gaxar- 1 . stone of Khaj

Ansart's tomb. has always been considered as a great mosque and holy shrine of the Islamic world. Before Islam, it was the place of worship of Arian mono-

The famous mosque of Ther suffered ruin seve ral times. This mosque ain. Project plans to house iniscences of the Timurid

3. Mosque of Herat: The mosque of Herat

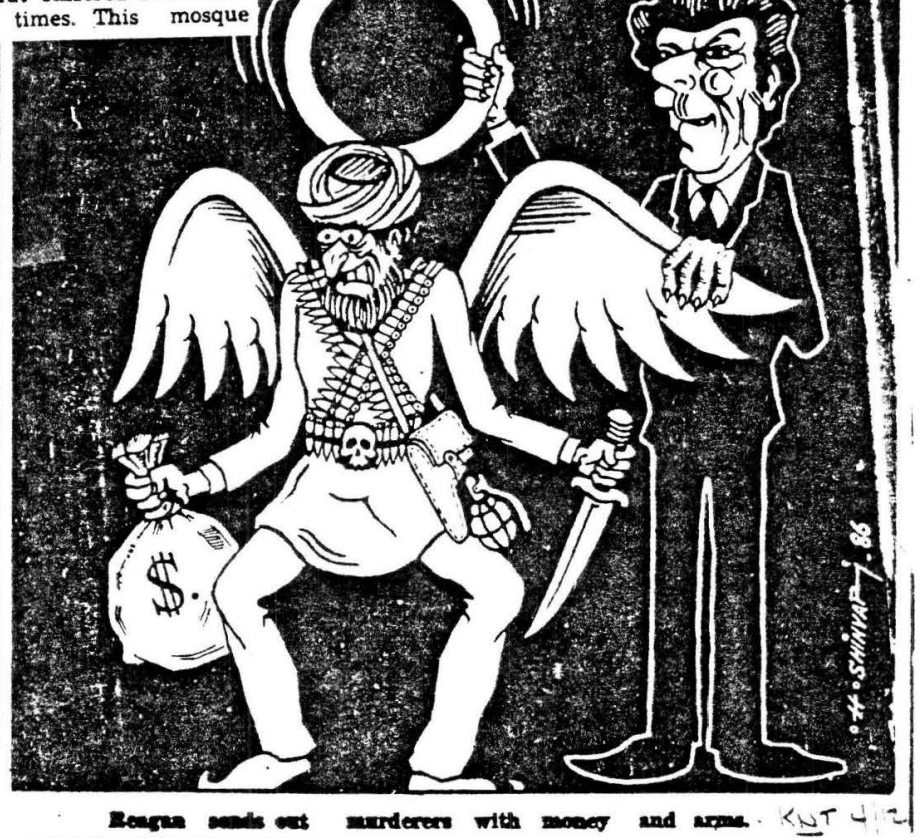

5. Mosque of Zleraterah. The mosque of Zlaratgah is one of the important relics of the Timurid period of Herat. It was rep1978. A long with the different ruined parts of the mosque, the western porch of the mosque was reconstructed skillfully.

6. Houze Sarposhida (Underground Basin)

People of Herat have used the big underground pools as reservoir of water for irrigation and other means from ancient times.

Charsouk and Malik are the most wonderful of all the underground pools of Herat.

Ise Charsouk uridergrnind tusin ilas a very Safawid Empire in 1045 (H.Q). This ancient monument especially its beautiful cupola is considdiaevel architecture. It is located in the middle of ancient Herat city, where artists and artisans work at their shops and looms, from dawn till evening. The basin will be a gallery of traditional handicrafts of Herat.

Malik basin is also a historical treasure of

Herat. It has a history of 500 years.

This underground ba $\sin$ is situated at the southern part of Ekhtiaruddin fortress.

The International Project of Herat began restoration works of the porches and root of the basin in 1985 .

By Z. Rasban

KNT $6 / 17$ aired comprehensively in thick ceiling, built during ered a masterpiece of me midde is a small heap the tomb of Sultan Hus-

4. Gymnadiom of Sul$\tan$ Husain-1-Balqra.

Hain of the Byminasium a. C. They stand at four corners of the gymnasium. In the rearen ands

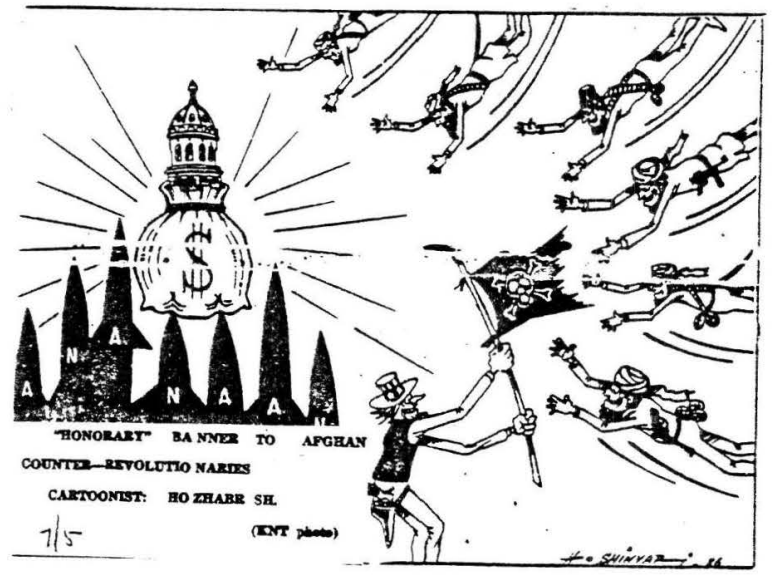




\section{Ustad Farida Mahwash}

\section{-Melody queen}

Ustad means a master. but to be more precise onlv an artist who has suffered life-long self-discipline in mastering an art can capture this title. The title of Ustad is conferad on outstanding and professional musicians.

The only woman who attained the honourazy title of Ustad in Afghanistan is Farida Mahwash, a vocalist of Radio and TV of the DRA.

She has recorded so fas over six hundred different songs for the radio and rade $150 \mathrm{TV}$ appearan-

Ustad Mahwash was born and grew up in an artisan family in an old street of Kabul called Guzar-i-Ali Raza Khan.

After primary education, she attended Zarghoona Lycee of Kabul.

She used to sing in the music programmes and concerts of the high school where her talents wa. re always appreciated. Then she became a pupil of late Ustad Nabi Gul. She also learned music from Nainawaz and the great Ustad of Afghan classical music Sar Ahane

Interviewed by a - KNT correspondent, she said. "To have a better understanding of music, I became a student of Ustad M. Hashim, well-known contemporary musician and instrumentalist of the country, in 1973. His versatile teachings enabl. ed me to follow my artb stic credo until now. Wost of my songs have been coinposed by the same $U_{2 n}$. tad.

Ustad Salim Sarmast, Ilafizullah Khiyal and Naisaz also composed so me popular songs for m. during recent years".

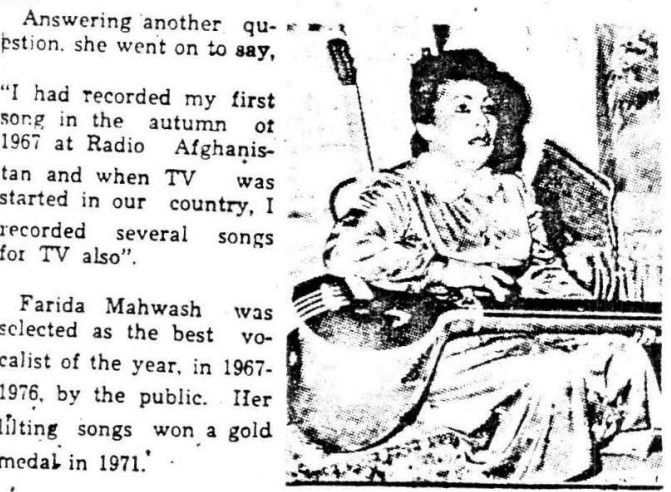

Stee was given the jiote of Uct:d :. :276, by the Culture and Information Ministry of the time.

Mahwash won fame, e2 rly in her career. Her melodious singing enjoys tremendous popularity among the public and her golden voice evokes deep emotions in her listeners.

Ustad Mahwash has toured many countries and given concerts. Among them are the USSR, Cze choslovakia, Iran, Pakistai1. the German Democratic Republic and India.

She participated in the Berlin International Music Festival and brought hume a diploma as well as a gold medal.

Ustad Mahwash can play harmonium and some string instruments such as tanbura and surmandar (both the classical musical instruments) fluently. She follows the classical Afghan music forms of Ghazal and Tumri.

This outstanding vocalist served as a clerk for many years .: lany state institutions. ildren.

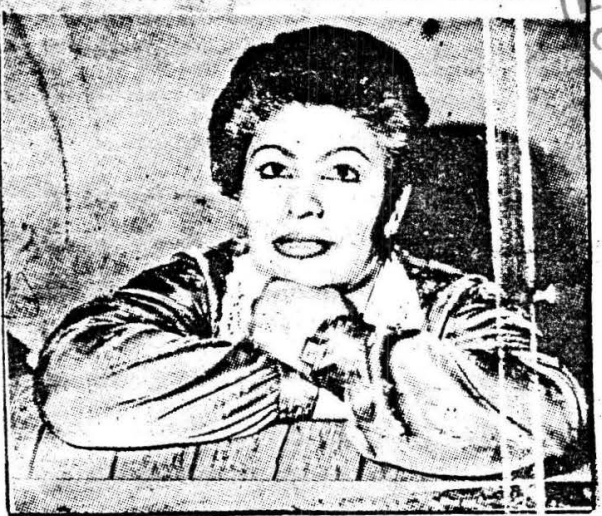

Since 1983, she has been working at the Musie Pro

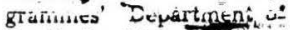
the Radio Afghanistan.

As well as being a member of the Central Council of the Union of Artists she is a member of the Central Council of the Women's Democratia Organisation of Afghanie tan. Ustad Mahwash is married and has five ch-

These days, she is rehearsing new songs and classical music to be pro sented at a special music programme of Radio Asghanistan entitled "Concert of the Ustads".

By: Zle Resban

个KNT 6/24

\section{The Dawn of Revolution}

The eximson commet ditrunes its da neli ax rave The varlegited bind commenece itdr phe Dusky cloods vanich from the stas Sly and land embrace enchother Dartoness succumbs to clear heavens. The homeland simmers with dedre. Life and love are rampant everywh re Tightly clapping each other With conrage and conflence Nelther cloud nor storm

Coald halt the star trom shining Penctratiog It glimmer on this cxich With love and loyalty to all people Shining star

You are love, rou are hope, you ars filth Yon are elan and enthnelam

You are strength, courage and con ind sence You are people's prido

You are the harbinger of peace a ad happlneses to the nation.

Shining tar

Your shimmering love

Is like the spring rain falling

On this dry earth
Restoring health to a fading plas: Resuscitating the drying saplin: Across dales and vales

In the depths of glens and gorg $*$

Over the hills and monntains

To the entire suppressed dweilers of the country

And their knowledse of Tor Coerces them feel choertal

And buttresses their falth in uf,

Shining star

You offer love and for

You share sorrow and glee with pe ople

Your care and fondle is wanne t $t$ las parents

You are noble and yours is a r oble love

Based upon the sense of moral tai 5

An immortal impolse of prow dị 5 hope and stamina

To the downtrodden tollers

A mammoth love that warran $a$ 'iting

You are stout guder in the m irch towards the glowing horkzons

You shed everlasting rays

With forwand Jump of April Re ofutton

With your lofty moral qualits

You infinitely love the people

You develop the people

As proud revolutionsies

And able builders of new sorlet

You embrace the masses

Calling for thelr anity

To fight the archenemies

You hoist the banner

Waving on the galaries and be ond

That is the final gosi

It is the prediction of my ool al (B' ( havs Amer) 

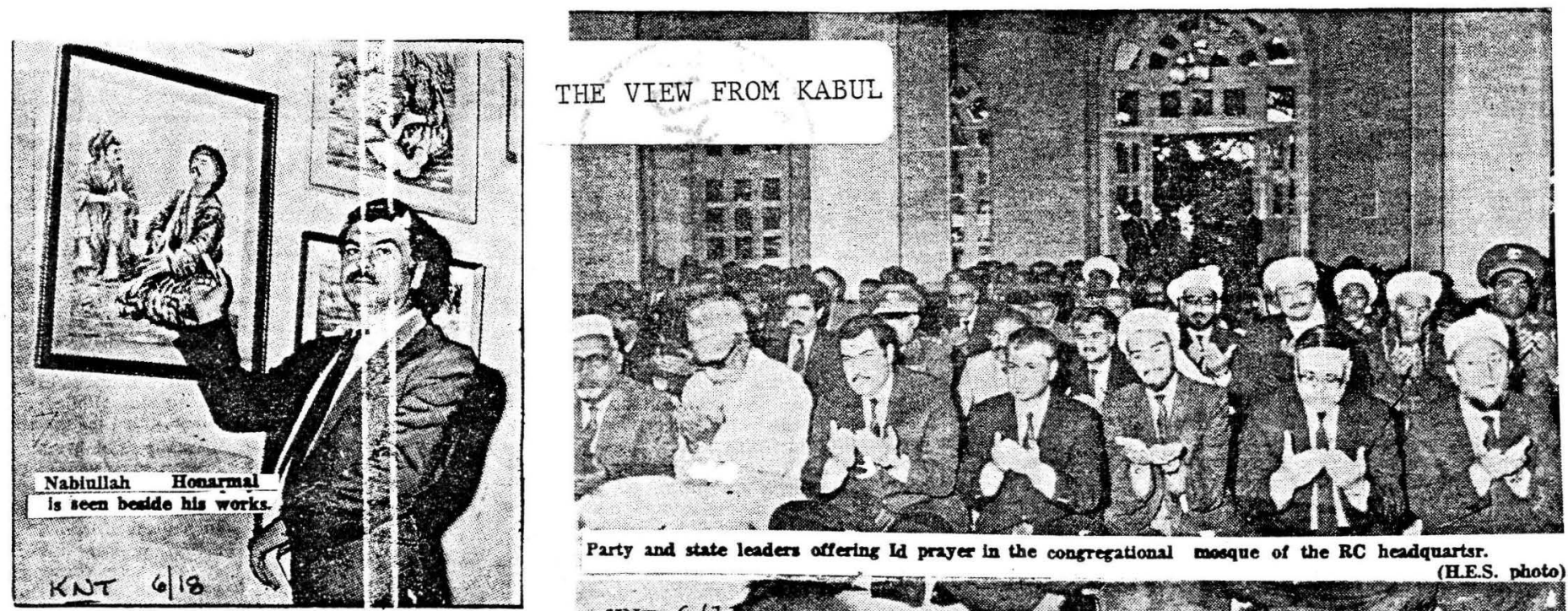

Party and state leaders offering Id prajer in the consregational mosque of the RC headquartsr.

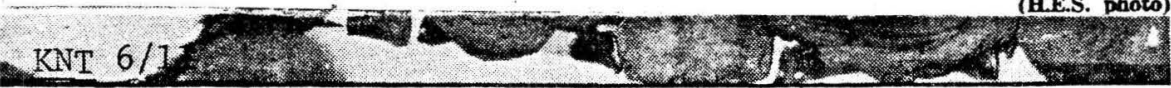
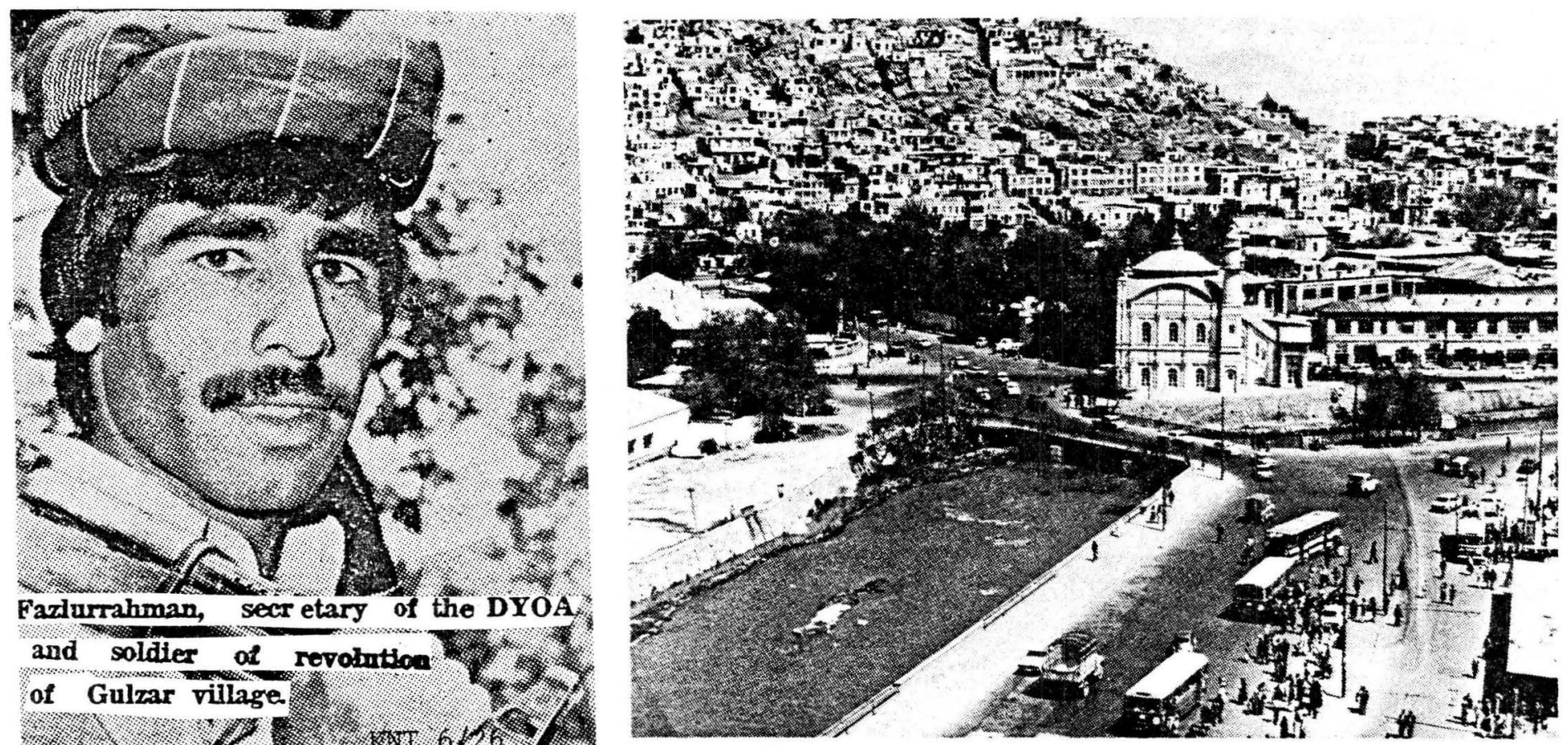

Fazdurrahman, secr etary of the DYOA.

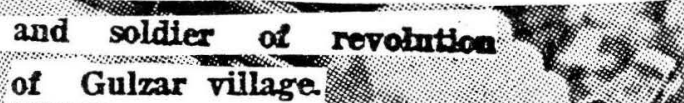

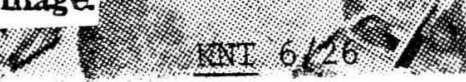

Photo: "Fighters for the Faith? No, Hired Killers!"
Nothing can hinder the triumphant new life in Afghanistan.
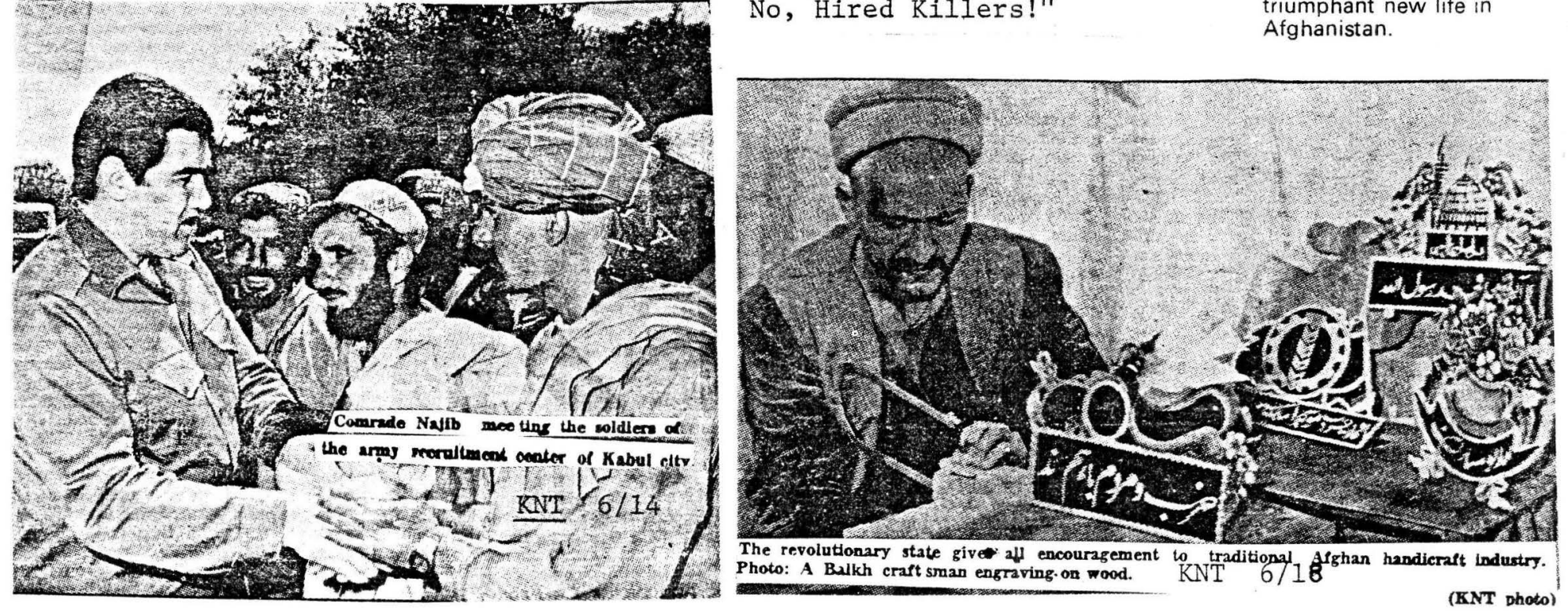